\title{
Bedrock Geology and
}

Asbestos Deposits of

the Upper Missisquoi Valley

and Vicinity, Vermont

GEOLOGICAL SURVEY BULLETIN 1122-B 


\section{Bedrock Geology and}

\section{Asbestos Deposits of}

the Upper Missisquoi Valley

and Vicinity, Vermont

By W. M. CADY, A. L. ALBEE, and A. H. CHIDESTER

CONTRIBUTIONS TO ECONOMIC GEOLOGY

GE OLOGICAL SURVEY B ULLE T I N $1122-$ B

Survey of an area in which 80 percent

of the asbestos produced in the

United States has been mined

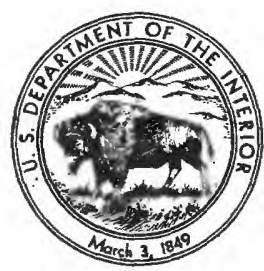




\section{UNITED STATES DEPARTMENT OF THE INTERIOR}

STEWART L. UDALL, Secretary

\section{GEOLOGIGAL SURVEY}

Thomas B. Nolan, Director 


\section{CONTENTS}

\begin{tabular}{|c|c|}
\hline & Page \\
\hline Abstract & $\mathrm{B}-1$ \\
\hline oduction & \\
\hline Geography & 3 \\
\hline Previous work & 4 \\
\hline Present investigation & 5 \\
\hline Acknowledgments . . . . . . . . & 5 \\
\hline eology & \\
\hline General statement & 6 \\
\hline Regional age correlations & 7 \\
\hline Metamorphosed sedimentary and volcanic rocks & 8 \\
\hline Hazens Notch formation & 11 \\
\hline Schist, gneiss, and quartzite & 11 \\
\hline Amphibolite & 13 \\
\hline Jay Peak formation & 13 \\
\hline Belvidere Mountain amphibolite & 15 \\
\hline formation & 18 \\
\hline Carbonaceous phyllite & 19 \\
\hline Carbonaceous quartzite & 19 \\
\hline ricite-chlorite phyllite & 20 \\
\hline Phyllitic graywacke & 21 \\
\hline ion & 22 \\
\hline Irtz-chlorite-albite schist and phyllite......... & 23 \\
\hline ceous quartz-sericite-chlorite schist and phyllite.... & 23 \\
\hline one & 24 \\
\hline 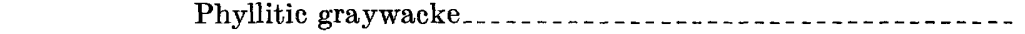 & 25 \\
\hline formation & 25 \\
\hline ation & 27 \\
\hline -albite-chlorite granulite $\ldots \ldots \ldots \ldots$ & 28 \\
\hline icite-chlorite phyllite-slate $\ldots \ldots$ & 29 \\
\hline oritic quartzite & 30 \\
\hline 11 volcanic member & 30 \\
\hline Shaw Mountain formation & 32 \\
\hline Quartz conglomerate & 32 \\
\hline lite & 32 \\
\hline limestone. & 33 \\
\hline - & 33 \\
\hline ks and associated alteration products $\ldots \ldots$ & 34 \\
\hline Ultramafic and associated rocks & 35 \\
\hline Distribution & 35 \\
\hline Lithologic description & 36 \\
\hline 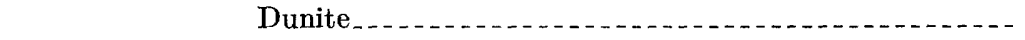 & 36 \\
\hline 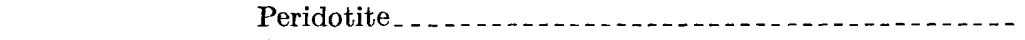 & 38 \\
\hline 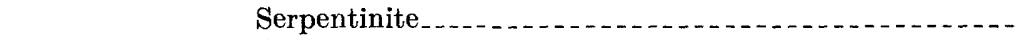 & 39 \\
\hline Calc-silicate rock & 41 \\
\hline
\end{tabular}


Geology-Continued

Intrusive igneous rocks and associated alteration products-Continued Ultramafic and associated rocks-Continued

Lithologic description-Continued

Antigorite-chlorite rock

Talc-carbonate rock

Page

$\mathrm{B}-42$

Carbonate rock

Steatite...

Chlorite rock

Genetic relationships...

Metagabbro_...

Eltey Mountain granite $\ldots$

Lamprophyre . .

Metamorphism_...

Structure

Major structural features...

Minor structural features..........

Bedding and bedding foliation

Layering in ultramafic rocks.

Folds and crinkles............ 59

Slip cleavage and transverse schistosity; fracture cleavage; fold

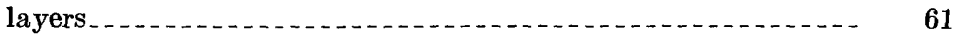

Other minor structures........ 62

Structural synthesis...... 63

Asbestos deposits

History and development... 67

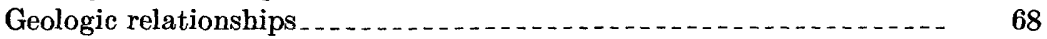

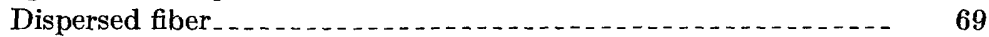

Slip- and cross-fiber veins $\ldots$

Other mineral resources . .

Talc

Iron

Chromite...

Copper... 72

References cited

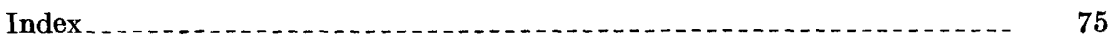

\section{ILLUSTRATIONS}

Plate 1. Geologic map and structure sections of the upper Missisquoi Valley and vicinity, Vermont.....................

Frgure 1. Index map showing location of the upper Missisquoi Valley and vicinity, Vermont

2. Diagrammatic sections illustrating the two principal types of zonal relations at the contacts of ultramafic plutons........

3. Large-scale diagram illustrating the relation between minor cross folds and minor folds of the longitudinal fold system .

4. Block diagram illustrating fold layers in interbedded granulite and quartzite- of the Moretown formation........... 


\section{TABLES}

Page

TABLE 1. Correlation of the rock formations of north-central Vermont

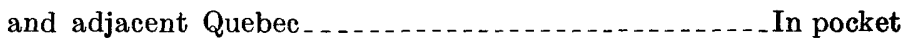

2. Estimated modes of selected metamorphosed sedimentary rocks

3. Estimated modes of selected metamorphosed volcanic rocks_- $\quad 10$

4. Estimated and measured modes of the intrusive igneous rocks _ $\quad 34$ 



\title{
CONTRIBUTIONS TO ECONOMIC GEOLOGY
}

\section{BEDROGK GEOLOGY AND ASBESTOS DEPOSITS OF THE UPPER MISSISQUOI VALLEY AND VICINITY, VERMONT}

\author{
By W. M. Cady, A. L. Albee, and A. H. Chidester
}

ABSTRACT

The upper Missisquoi Valley and vicinity as described in this report covers an area of about 250 square miles at the headwaters of the Missisquoi River in northcentral Vermont. About 90 percent of the area is forested and the remainder is chiefly farm land.

The topography reflects the geologic structure and varied resistance of the bedrock to erosion. Most of the area is on the east limb of the Green Mountain anticlinorium, which is the principal structural feature of Vermont. The bedrock is predominantly sedimentary and volcanic rock that has been regionally metamorphosed. It was intruded before metamorphism by mafic and ultramafic igneous rocks, and after metamorphism by felsic and mafic igneous rocks. The metamorphosed sedimentary and volcanic rocks range in age from Cambrian(?) to Middle Silurian, the intrusive igneous rocks from probably Late Ordovician to probably late Permian. Metamorphism and principal folding in the region occurred in Middle Devonian time.

The metamorphosed sedimentary and volcanic rocks make up a section at least 25,000 feet thick and can be divided into nine formations. The Hazens Notch formation of Cambrian(?) and Early Cambrian age is characterized by carbonaceous schist. It is succeeded in western parts of the area by the Jay Peak formation of Early Cambrian age, which is chiefly a schist that is distinguished by the general absence of carbonaceous zones; in central parts of the area the Hazens Notch formation is followed by the Belvidere Mountain amphibolite, probably the youngest of the formations of Early Cambrian age. The Ottauquechee formation, composed of carbonaceous phyllite and quartzite, and phyllitic graywacke, is of Middle Cambrian age. The Stowe formation of Late Cambrian(?) and Early(?) Ordovician age overlies the Ottauquechee and is predominantly noncarbonaceous schist, though it also contains greenstone and carbonaceous schist and phyllite. The Umbrella Hill formation of Middle Ordovician age is characteristically a conglomerate in which the mineral chloritoid is common. The overlying Moretown formation, also of Middle Ordovician age, contains granulite and slate, also greenstone and amphibolite of the Coburn Hill volcanic member. The Shaw Mountain formation, made up of conglomerate, phyllite, and limestone, is the oldest Silurian unit. The Shaw Mountain formation is succeeded by the Northfield slate of Middle Silurian age.

The igneous rocks of the region include various ultramafic plutonic rocks, such as dunite, peridotite, and serpentinite, probably of Late Ordovician age; sills and nearly concordant dikes of metagabbro of Late Ordovician age; biotite granite 
plutons or Middle or Late Devonian age, most notably on Eltey Mountain; and hypabyssal lamprophyre, probably of late Permian age.

Metamorphic zoning is shown by the distribution of rocks of the epidote-amphibolite facies and the greenschist facies in and near the Green Mountains, and near Coburn Hill and Eltey Mountain. Metasomatism related to regional metamorphism has produced porphyroblasts and quartz segregations in the sedimentary and volcanic rocks, and steatitization and carbonatization of serpentinite. Contact metamorphism has formed rocks of the epidote-amphibolite facies near granite plutons, and probably calc-silicate rock at the contacts of ultramafic plutons.

The axial anticline of the Green Mountain anticlinorium and other anticlines and synclines to the east are the major longitudinal structural features of the area. These structures are complicated by transverse folds, particularly a syncline in the vicinity of Tillotson Peak. Early minor cross folds that are best developed in the Hazens Notch formation are believed to be genetically related to the transverse folds. The axial planes of the cross folds are folded about the axes of the later longitudinal folds of the Green Mountain anticlinorium. The longitudinal and transverse fold systems probably formed in the same episode of deformation. Original structural features are bedding, in the metamorphosed sedimentary and volcanic rocks, and possibly layering, in the ultramafic intrusive rocks; secondary features include folds, slip cleavage, fracture cleavage, fold layers, joints, faults, shear zones, and shear polyhedrons, as well as foliation developed parallel to the various primary and secondary planar features. Common linear features are fold and crinkle axes, quartz rods, and elongated quartz lenses.

Asbestos has been mined from four quarries near Belvidere Mountain during the past 75 years; present production is from the Lowell quarry and from the C-area quarry. The principal physical exploration for asbestos in the upper Missisquoi Valley area has been during the past 15 years.

Slip-fiber asbestos dispersed in schistose serpentinite forms the richest and proportionately the most abundant type of ore in the Lowell Quarry and C-area deposits. Veins of cross- and slip-fiber asbestos, associated with dunite or massive serpentinite, are significant but commercially less important sources of fiber. In the well-exposed quarry areas, the zones of schistose serpentinite are larger at and near the borders of the ultramafic rock. In other areas, the margins of the ultramafic plutons are largely covered by surficial deposits, but are inferred to be chiefly schistose serpentinite. Most prospect pits are in outcrops of massive serpentinite or dunite that expose veins of cross-fiber asbestos. The covered areas at the margins of the bodies of ultramafic rock appear to be likely sites for future exploration by diamond drilling.

Talc is a potential, though unexploited, mineral resource of the upper Missisquoi Valley area. Large amounts of talc in the form of talc-carbonate rock occur in a belt at least 4 miles long and from 100 to 1,500 feet wide in the town of Troy.

Other occurrences of economic mineral commodities include iron ore, which was mined and smelted locally more than 100 years ago, chromite, and possibly copper.

\section{INTRODUCTION}

This report describes the geology and mineral resources of the upper Missisquoi Valley and vicinity. The area mapped consists of approximately 250 square miles and is immediately south of the international boundary with the province of Quebec, Canada (see fig. 1) in and east of the Green Mountains in north-central Vermont. Included are parts of the areas of the Jay Peak, Irasburg, Hyde Park, 


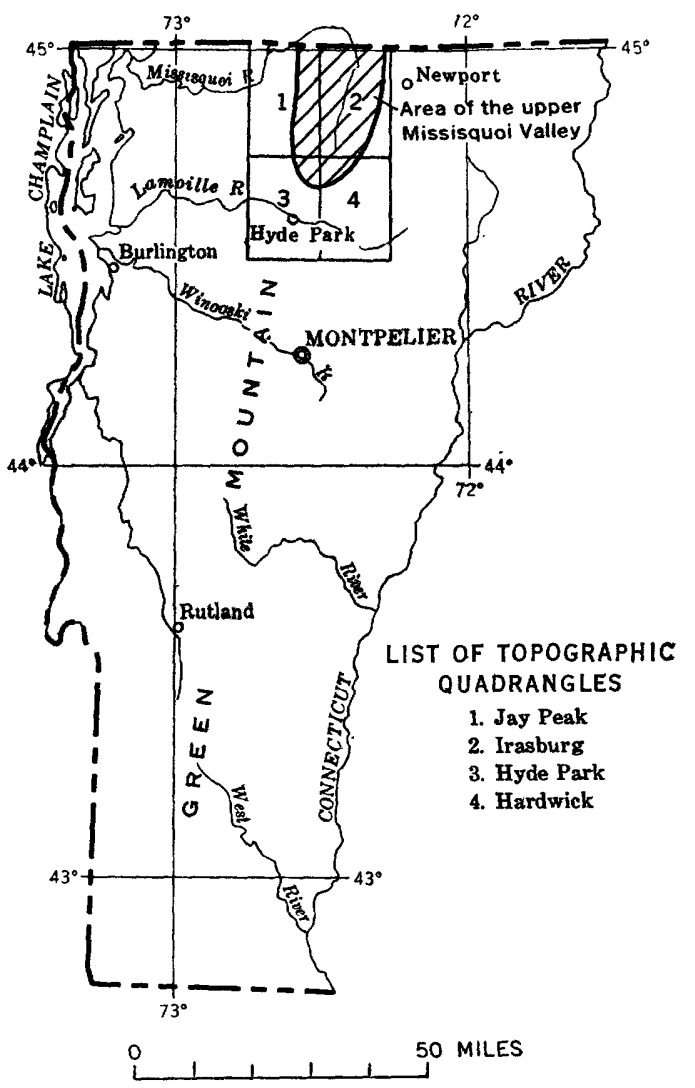

Figure 1.-Index map showing location of the upper Missisquoi Valley and vicinity, Vermont.

and Hardwick 15-minute topographic quadrangle maps published by the U.S. Geological Survey.

\section{GEOGRAPHY}

The north-trending ridge of the Green Mountains is the western limit of the upper Missisquoi Valley. The Lowell Mountains make up a relatively low ridge that trends northeast in the area southeast of the upper Missisquoi Valley and Lake Eden. Between the two mountain ranges are small ranges of hills and scattered isolated mountains; the sharp peak of Mount Norris, and Hadley Mountain to the west, are distinctive landmarks. Bear Mountain is a landmark on the international boundary east of the upper Missisquoi Valley. Altitudes range from 520 feet, where the upper Missisquoi River crosses the international boundary near North Troy, to 3,870 feet at the summit of Jay Peak, which is the highest of the Green Mountains in the area. 
The upper Missisquoi River drains most of the area (pl. 1). It flows northward through the central part of the area into Quebec, thence westward across the northern extension of the Green Mountains (Sutton Mountains). In its lower course the Missisquoi River reenters Vermont about a quarter of a mile west of the northwest corner of the area of the map, whence it flows westward to Lake Champlain (fig. 1). The southernmost part of the area drains chiefly to the southwest through Lake Eden and the Gihon River (pl. 1) into the Lamoille River.

In addition to the main highways (State Routes 14, 58, 100, 101, $105,105-\mathrm{A}$, and 118) networks of secondary roads are maintained in all but the most mountainous terrains. The Long 'Trail of the Green Mountain Club, and several trails that approach it, furnish access to the summit ridge of the Green Mountains.

The Canadian Pacific Railroad serves the area with stations near East Richford (Stevens Mills and Missisquoi stations) and at North Troy and Newport Center. The St. Johnsbury and Lamoille County Railroad provides freight service with stations at Hyde Park, Morrisville, and Johnson about 10 miles by hard-surfaced road south of the area; Hyde Park and Morrisville are the shipping points for asbestos fiber trucked from the Lowell-Eden area. The nearest municipal airport is that of the city of Newport; this airport is about 3 miles east of the area of the map and 8 miles by road southeast of Newport Center. A port of entry from Canada for U.S. Customs and Immigration is at North Troy; another port of entry is at East Richford. Canadian ports of entry are maintained near East Richford, at Highwater, Quebec, north of North Troy, 1.5 miles northeast of North Troy, and 0.8 mile east of the summit of Bear Mountain a little east of the map area.

The principal industry of the upper Missisquoi Valley and vicinity is dairy farming and related activity, including cheese making. Asbestos mining is second in importance. The asbestos mine of the Vermont Asbestos Mines Division of the Ruberoid Co. in the towns of Lowell and Eden employs about 300 people and in 1961 shipped approximately 85 percent of the asbestos mined in the United States. The third most important industry is logging and woodworking, notably the manufacture of plywood, lumber, and spinning bobbins.

\section{PREVIOUS WORK}

Geologic work in the area goes back more than 100 years, though the first organized effort was that of the Hitchcock survey of the State of Vermont (Hitchcock and others, 1861). The principal published works since that survey have been those of Kemp (1901); Marsters (1904, 1905, 1906); Richardson (1908, 1910, 1911, 1912); Richardson 
and Collister (1912); Richardson and Conway (1912); Keith and Bain (1932) ; Bain (1932, 1936), and Albee (1957). One report of Richardson's (1910) and the works of Keith and Bain, just cited, deal specifically with the asbestos deposits and associated ultramafic rocks.

Significant recent investigations in nearby areas are those of Doll (1951) to the east, and of Ambrose $(1942,1943)$, Clark (1934, 1936a), Clark and Fairbairn (1936), Cooke (1950, 1951), and Fairbairn (1933) north of the international boundary in Quebec. These studies are concerned with the general geologic relations rather than with the mineral deposits. Cooke (1937, p. 59-140), Dresser (1913), Dresser and Denis (1944, p. 413-447), and Riordon (1954, 1955) have contributed valuable discussions of the asbestos deposits and associated ultramafic rocks in Quebec.

\section{PRESENT INVESTIGATION}

The geologic mapping was done during the period 1952-56, at scale $1: 24,000$, on a topographic base map specially compiled by multiplex methods; a narrow strip on the extreme east side of the map was revised from the earlier Irasburg 15-minute quadrangle map. The total time spent in fieldwork was 23 man-months. Cady and Albee made the petrographic studies and compiled the final map, and Cady wrote the report in consultation with Albee and Chidester.

The asbestos deposits and related ultramafic rocks in the vicinity of Belvidere Mountain and the contacts of ultramafic rocks in certain other small areas were mapped by plane-table methods. Some of these data are included in the geologic map (pl. 1), but more will be published at a larger scale in a future report on the geology and asbestos deposits of the vicinity of Belvidere Mountain.

\section{ACKNOWLEDGMENTS}

The authors thank the Vermont Asbestos Mines, other owners of surface and mining rights, and the people of the area for their friendly cooperation during this investigation. I. E. Matthews, superintendent, and members of the exploration staff of Vermont Asbestos Mines, particularly J. K. Gilmore, Louis Jordan, and David Nichols, have been especially helpful. The exploration staff, in the course of ground magnetometer surveys, located the contacts of ultramafic igneous bodies in many areas that are covered by overburden. The company generously turned over the data to the Geological Survey for incorporation in the geologic map of the Missisquoi Valley and vicinity.

The authors also wish to acknowledge the help of other geologists working in the region, who through field conference, discussion, and suggestion have contributed to the information and interpretations presented in this report. The late Dr. H. C. Cooke, of the Geological Survey of Canada and of the Geological Surveys Branch of the Quebec 
Department of Mines, kindly conducted the geologists of the U.S. Geological Survey on yearly excursions in adjacent Quebec. To Professor T. H. Clerk, of McGill University, and to Dr. Peter Riordon, of the Asbestos Corp., Limited, we are also indebted for introductions to the Sutton and Thetford Mines areas, respectively, in Quebec. Drs. M. J. Rickard and H. S. de Römer, formerly of McGill, who have mapped areas in Quebec immediately north of that of the present study, have led tours of these areas and provided a manuscript map in advance of publication. Dr. C. G. Doll, of the Vermont Geological Survey, introduced the senior author to the Belvidere Mountain area and to the critical area between Lake Memphremagog and Irasburg that adjoins that of the present study on the east. Professor P. H. Osberg, of the University of Maine, has participated with the authors for several years in field and laboratory studies pertaining to east-west stratigraphic correlation across the Green and Sutton Mountains. It was through Osberg's fieldwork in Quebec, which was part of a project supported by the Geological Society of America, that the correlations used in this report have been demonstrated.

The authors are particularly indebted to Dr. J. R. Béland, Regional Geologist of the Quebec Department of Natural Resources, and to Professor F. F. Osborne, of Laval University, for critiques of the regional studies in Vermont and adjacent Quebec, connected with the present investigation.

\section{GEOLOGY}

\section{GENERAL STATEMENT}

The topography reflects not only the structural trends and varied resistance to erosion of the bedrock, but also the effects of glaciation upon the general area. The general pattern of stream dissection has been slightly modified by glacial action. Continental glaciation has rounded and striated the bedrock of the summit peaks. Deep cirques, such as that between Jay Peak and Big Jay (pl. 1), indicate that alpine glaciers occurred locally. Clay, silt, sand, and gravel that have accumulated in the valleys and rocky glacial soil that is spread over the mountain slopes contribute to the smooth features of the land surface. Eskers at Lake Eden and south of Corez Pond in the town of Eden are prominent depositional features. In several areas surficial deposits (not mapped) are particularly extensive. Structure symbols are absent or widely scattered for these areas (pl. 1).

Most of the area of this study is on the east limb of the Green Mountain anticlinorium, whose crestline trends north-northeast across the extreme northwestern part of the area. The Green Mountain anticlinorium is the principal structural feature of Vermont and also of adjacent Quebec, where it is referred to as the Sutton Mountain 
anticlinorium; it extends from the southern boundary of Vermont north-northeast through the State for 160 miles and for about 150 miles into Quebec. The general eastward dip of the rocks in the east limb of the anticlinorium is interrupted by rather large subsidiary anticlines and synclines.

The area is mostly underlain by metasedimentary and metavolcanic rocks ranging in age from Cambrian(?) to Middle Silurian. The protoliths of the metasedimentary rocks were shale, graywacke, quartz sandstone, probably some chert, quartz and shale pebble conglomerate, and a little limestone; the protoliths of the metavolcanic rocks probably were basalt flows and detritus eroded from the flows, and rhyolite flows and tuffs. The metamorphic products are slate, phyllite, schist, gneiss, phyllitic graywacke, granulite, quartzite, quartzitic and phyllitic conglomerate, crystalline limestone, greenstone, and amphibolite. The sedimentary and volcanic rocks were intruded-before regional metamorphism-by dunite, peridotite, serpentinite, and gabbro. These intrusive rocks were altered to metagabbro, talc-carbonate rock, and steatite during regional metamorphism in Middle Devonian time. Most of the metamorphic rocks are intruded by granite of Devonian age and lamprophyre probably as young as late Permian.

\section{REGIONAL AGE CORRELATIONS}

The rock units are shown on the geologic map and structure sections (pl. 1). Their geologic ages and correlation with units in adjacent areas are indicated on table 1 . Certain of these age assignments and correlations differ from published usage, as indicated in footnotes 4 to 7 of the table. These differences are discussed at length elsewhere (Cady, 1960, p. 545-556, pl. 3).

The Hazens Notch and Jay Peak formations, named in this report, and the Belvidere Mountain amphibolite are probably of Early Cambrian age, since they are beneath and grade in to the Ottauquechee formation, which correlates stratigraphically (Cady, 1960, p. 548, 554; Osberg, 1956, p. 1820) with fossiliferous Middle Cambrian strata west of the Green Mountain anticlinorium. They are parts of the Camels Hump group (Albee, 1957; Cady, 1956), which in west-central Vermont rests unconformably on Precambrian rocks and contains formations of Cambrian(?) age. ${ }^{1}$ The Stowe formation, lying between the Middle Cambrian Ottauquechee formation and the Middle Ordovician Umbrella Hill and Moretown formations, is assigned to

\footnotetext{
1 The basal unit of the Camels Hump group in west-central Vermont, the Pinnacle formation, is in a section that is conformable with, but stratigraphically beneath, the fossiliferous Lower Cambrian in northwestern Vermont and nearby parts of Quebec (Booth, 1950, p. 1137; Clark, 1936b, p. 146). Such sections are assigned an age of Cambrian (?) in the practice of the U.S. Geological Survey. Accordingly, the lower part of the Camels Hump group is of Cambrian(?) age.
} 
the Late Cambrian(?) and Early(?) Ordovician because it is the equivalent of the upper Mansonville slates of Clark (1934, p. 11) in Quebec, which, in turn, correlate with strata of about the Late Cambrian to Early Ordovician time span west of the Green MountainSutton Mountain anticlinorium (Cady, 1960, p. 549, 559; Osberg, 1956). The Umbrella Hill formation is at least locally unconformable on the Stowe and grades into the overlying Moretown formation; therefore, it is assigned a Middle Ordovician age. The Moretown is directly traceable into slates in Quebec that contain Middle Ordovician fossils (Ambrose, 1942; Clark, 1934, p. 11; Cooke, 1950, p. 45-48). The Shaw Mountain and Northfield formations are assigned a Silurian age because of their sequential and lithic similarity (Cady, 1960 , p. 551, 555-556) to the Silurian Peasley Pond conglomerate and Glenbrooke shale (Clark, 1936a, p. 33) in Quebec. Specifically, the Shaw Mountain is of Early or Middle Silurian age and the Northfield is Middle Silurian.

The ultramafic rocks and the metagabbro are assigned to the Ordovician, inasmuch as neither is known to intrude strata younger than Ordovician in the Green Mountain-Sutton Mountain anticlinorium of northern Vermont and adjacent Quebec (Cady and Chidester, 1957). Furthermore, pebbles of serpentinite from the ultramafic rocks are reported in the Silurian Peasley Pond conglomerate in Quebec (Clark and Fairbairn, 1936, p. 16). The Eltey Mountain granite, named herein, is assigned to the Devonian and the lamprophyre to the late Permian(?), in correspondence with age assignments of similar rocks to the southeast in east-central Vermont (Lyons and others, 1957, p. 532-534, 538-542, 544; White and Billings, 1951, p. 662). ${ }^{2}$

Metamorphism and principal folding in the region took place in Middle Devonian time (Billings, 1948, p. 52; Cady, 1945, p. 580; Cady, 1960 , p. $563-564)^{3}$

\section{METAMORPHOSED SEDIMENTARY AND VOLCANIC ROCKS}

The most common type of metamorphosed sedimentary rock in the area is quartz-sericite $e^{4}$-chlorite-albite schist. All gradations of composition are found between the schists, and rocks such as quartzite, albite gneiss, and granulite, or sericite slate and phyllite, in which one or two of the major constituents far outweigh the others. Estimated modes of specimens of metamorphosed sedimentary rocks are shown in table 2. The specimens chosen for modal analysis were selected

2 After this manuscript was prepared, revisions in the geologic time-scale, mainly expansion in the time intervals, place correlatives of the lamprophyre that have been radiometrically dated in the Jurassic rather than in the Permian. Comparable reductions in the minimum geologic age of the granites have resulted (Holmes, 1960; Kulp, 1961).

${ }_{3}$ Expansion of the time intervals of the geologic time scale has also reduced the minimum geologic age of metamorphism and folding in the region, as deduced from radiometric age measurements of schists and granitic rocks that transect folds. The result is that some of the metamorphism and folding may be as young as Permian.

Sericite is used in this report to refer to fine-grained white mica, including muscovite, paragonite, and possibly other minerals. 
from 166 thin sections (exclusive of conglomerate) in which the order of abundance of contained minerals had been determined chiefly by inspection. Specimens that most nearly approximate the median in each common, geographically representative rock type were then selected for analysis. The analyses were made using comparison charts for visual estimation of percentage composition (Terry and Chilingar, 1955); values for the most abundant constituent, commonly quartz, are adjusted to attain totals of 100 percent. Segregations of coarse quartz that were avoided in thin sectioning commonly make up 10 to 20 percent of the schist, and lesser amounts in the gneiss and phyllite, so the overall quartz content of these rocks is proportionately greater than the modal estimates would indicate.

TABLE 2.-Estimated modes of selected metamorphosed sedimentary rocks

\begin{tabular}{|c|c|c|c|c|c|c|c|c|c|c|c|c|c|c|}
\hline & 1 & 2 & 3 & 4 & 5 & 6 & 7 & 8 & 9 & 10 & 11 & 12 & 13 & 14 \\
\hline Quartz... & $\begin{array}{l}38 \\
30\end{array}$ & 52 & 20 & 92 & 53 & 79 & 35 & 60 & 48 & 15 & 80 & 63 & 78 & $\begin{array}{l}60 \\
40\end{array}$ \\
\hline Chlorite. & 15 & 15 & Tr. & Tr. & 10 & Tr. & 15 & 5 & 20 & & 10 & 15 & 10 & \\
\hline Albite & 15 & 5 & & & 5 & 5 & 10 & 5 & 5 & & 5 & & & \\
\hline Imenite. & & 2 & & & & & & & 2 & 4 & Tr. & & 2 & Tr. \\
\hline Leucoxene. & $-\infty$ & 1 & $\ldots$ & $-\cdots$ & & & $\mathrm{Tr}$. & Tr. & -...- & $\mathbf{i}$ & 5 & & $\operatorname{Tr}$. & $T$ \\
\hline Sphene. & - & Tr. & & & 2 & Tr. & & & $\cdots-$ & & $\ldots$ & 2 & Tr. & \\
\hline $\begin{array}{l}\text { Carbon--- } \\
\text { Magnetit }\end{array}$ & $-\overline{2}$ & & 5 & 3 & $\mid---$ & Tr. & & 2 & & & & $\mathrm{Tr}$ & & $r$. \\
\hline Apa & Tr. & $\mathrm{Tr}$. & & & $\mathrm{Tr}$. & & & & $\mathrm{Tr}$. & Tr. & & & $\mathrm{Tr}$. & \\
\hline & & & & & & & Tr. & & Tr. & & Tr. & & Tr. & Tr. \\
\hline Chlo & $-\ldots$ & $-\ldots$ & $\ldots$ & $\ldots$ & $-\cdots$ & & & & 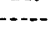 & 5 & & & & - \\
\hline Calc & ... & & & & $\ldots$ & 1 & & 3 & & & & & & - \\
\hline Lin & & -- & $\ldots$ & & $-\infty$ & & 1 & & ( & & & & & -- \\
\hline Epid & Tr. & & & $\ldots$ & & Tr. & & - & (n) & 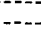 & & & $\ldots$ & -- \\
\hline Pel & & & & & 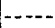 & Tr. & & & & 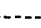 & & & & \\
\hline Ruti & & - & -- &.- & $\ldots$ & -...- & $\cdots$ & Tr. & -..- & &.--- & $-\ldots$ & & - \\
\hline Gar & $\mathrm{Tr}$. & & & & -- & & & & & & & & & \\
\hline Zir & & $\cdots$ & (n) & (n) & $\cdots$ & $\cdots$ & (n) & (n) & ( & $\cdots$ & $\cdots$ & 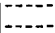 & Tr. & -- \\
\hline & - & & & & $\ldots$ & Tr. & & & & & & & & \\
\hline lanite & Tr. & $\ldots$ & & 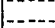 & $-\cdots$ & 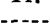 & & 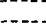 & $\ldots$ & & & & $\ldots$ & \\
\hline
\end{tabular}

Hazens Notch formation:

Explanation

1. Quartz-sericite-chlorite-albite schist (AA-2213) 3.0 miles N. $70^{\circ}$ W. of village of Jay.

Jay Peak formation:

2. Quartz-sericite-chlorite-albite schist (AA-1906) 1.0 mile S. $28^{\circ}$ W. of Burnt Mountain, Montgomery. Ottauquechee formation:

3. Carbonaceous phyllite (A Ch-54-405-A) 1.2 miles S. $50^{\circ}$ E. of street triangle at North Troy.

4. Carbonaceous quartzite (ACh-54-213-A) 0.06 mile east of highway from Troy to North Troy, in bed of Jay Branch.

5. Quartz-sericite-chlorite-phyllite (ACh-54-282) 2.0 miles S. $10^{\circ} \mathrm{W}$. of North Troy, a little east of the highway.

6. Phyllitic graywacke (AC-1204) 1.35 miles S. $50^{\circ}$ E. of street triangle at North Troy. Stowe formation:

7. Sericite-quartz-chlorite-albite phyllite (AA-1083) 0.1 mile N. $45^{\circ}$ W. of Eden Notch.

8. Carbonaceous quartz-sericite-chlorite schist (AC-1282) 2.5 miles $\mathrm{S.} 65^{\circ} \mathrm{E}$. of Eden Mills.

9. Phyllitic gray wacke (AA-2153-A) 0.8 mile N. $50^{\circ}$ E. of easterm summit of Leland Hill, Lowell.

Umbrella Hill formation:

10. Quartz-sericite-chloritoid slate (AA-1521) 1.7 miles S. 65 E. of Eden Noteh, near Eden-Lowell town line.

Moretown formation:

11. Quartz-sericite-albite-chlorite granulite (ACh-54-383-B) 0.9 mile S. $10^{\circ} \mathrm{E}$. of Big Falls, Troy.

12. Quartz-sericite-chlorite slate ( $\mathrm{AC}-83) 1.45$ miles $\mathrm{S} .56^{\circ} \mathrm{E}$. of road intersection (Routes 100 and 58 ) at Lowell village.

13. Sericitic and chloritic quartzite (AC-1248) 3.5 miles S. $71^{\circ} \mathrm{E}$. of Eden Mills. Northfield slate:

14. Quartz-sericite slate (A.C-1092-B) 1.15 miles S. $22^{\circ}$ W. of summit of Eltey Mountain, Irasburg.

Hornblende-epidote-albite amphibolite is the most common type of metamorphosed volcanic rock in the area; actinolite-epidote-chlo- 
rite-albite greenstone occurs in zones less strongly affected by metamorphism. Estimated modes of selected specimens of metamorphosed volcanic rock chosen from 72 thin sections are shown in table 3 . The five specimens selected for modal analysis were chosen and estimates made in the same manner as typical specimens of the metamorphosed sedimentary rocks.

TABLE 3.-Estimated modes of selected metamorphosed volcanic rocks

\begin{tabular}{|c|c|c|c|c|c|}
\hline & 1 & 2 & $\mathbf{3}$ & 4 & 5 \\
\hline Hornblende. & 40 & 65 & & & 40 \\
\hline Actinolite & & & & 35 & \\
\hline Epidote-clinozoisite. & 30 & 15 & 50 & 25 & 30 \\
\hline Albite & 5 & 15 & 3 & 15 & 25 \\
\hline Chlorite...2 & 20 & 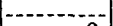 & 25 & 10 & 1 \\
\hline Sphene-1-2 & 3 & 2 & Tr. & 5 & 3 \\
\hline Biotite & $--2-2-n$ & 3 & $-\ldots$ & 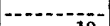 & \\
\hline Calcite. & $-\cdots-1-2$ & $-\cdots+\cdots-1$ & 2 & 10 & $-\cdots$ \\
\hline Ilmenite & Tr. & $-\ldots$ & Tr. & ---1 & $\operatorname{Tr}$ \\
\hline Pyrite. & Tr. & $-\cdots-$ & $--\rightarrow-$ & $-\cdots+$ & -- \\
\hline Hematite. & Tr. & 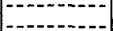 & $-\cdots$ & - & \\
\hline Almandite... & Tr. & 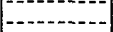 & 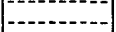 & (-n-n & 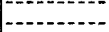 \\
\hline Rutile_. & Tr. & $-2-$ & 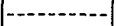 & $-1--$ & $-\cdots$ \\
\hline
\end{tabular}

Explanation

Hazens Notch formation:

1. Amphibolite (AA-1332) 1.0 mile west of Hazens Notch.

Belvidere Mountain amphibolite:

2. Amphibolite (AV-148) from septum at the northwest end of the ultramafic pluton, at Lowell Quarry. Stowe formation:

3. Greenstone (ACh-54-276-E) 1.5 miles S. $25^{\circ} \mathrm{E}$. of street triangle in North Troy.

Coburn Hill volcanic member of the Moretown formation:
4. Greenstone (AC-1042) 0.7 mile N. $20^{\circ}$ E. of Summit Siding on Canadian Pacific R. R., Newport.

5. Amphibolite (AC-1357-B) 0.25 mile northeast of Center Cemetery, Newport.

A principal distinguishing feature of the metamorphosed sedimentary and volcanic rocks is their bedding, which reflects original differences in texture and composition of successive layers or groups of layers as the result of sedimentary or volcanic stratification. The degree of certainty with which layering can be correlated with bedding depends upon contrasts in texture and composition and, to some extent, upon the size of the units under consideration. Units of conglomerate, quartzite, and limestone are probably most reliably interpreted as beds; compositional layering within such units can generally be accepted as bedding if the deformation is not too great, if the layers persist for more than about ten times their thickness, and if there is reasonable agreement between the attitude of the finer layering and of the larger units. Greenstone and amphibolite units within schist and gneiss generally seem to represent beds, but fine layering within them is perhaps not as reliable. Generally, layers in schist, gneiss, and granulite can be identified with certainty as parallel to bedding only where interbeds of conglomerate, limestone, quartzite, or greenstone are also present. Elsewhere the layering might be due to segregation of metamorphic minerals parallel to bedding or to cleavage that transects bedding. Graywacke is massive and shows little if any 
bedding even in its unmetamorphosed state; slate and phyllite may also lack bedding, but where it does occur it shows as faint traces on planes of cleavage or schistosity.

Three new stratigraphic units are introduced in this report. These are the Hazens Notch formation, the Jay Peak formation, and the Coburn Hill volcanic member of the Moretown formation. Typical and characteristic sections of these units are located in some detail as part of their introductory definitions.

\section{HAZENS NOTCH FORMATION}

The Hazens Notch formation is herein named for its exposure in cliffs immediately north of Hazens Notch in the southwestern part of the town of Westfield. It is chiefly interbedded carbonaceous and noncarbonaceous quartz-sericite-albite-chlorite schist, which grades imperceptibly into less abundant gneiss of similar composition and quartzite. Amphibolite occurs as interbedded tabular bodies, mostly within the schist and gneiss. A more characteristic section is exposed along or near Highway 105-A across the Green Mountains in the towns of Troy and Jay. The lowest rocks in this section are at the axis of the Green Mountain anticlinorium in the town of Jay, and the uppermost are near the highway from Troy to North Troy, 6 miles to the east. The apparent thickness ${ }^{5}$ of the exposed part of the formation is about 15,000 feet.

The Hazens Notch formation extends southward along its strike into the Camels Hump group in the Hyde Park quadrangle (Albee, 1957), where it makes up nost of this unit. There it is composed of carbonaceous and noncarbonaceous quartz-sericite-albite-chlorite gneiss, and schist in which the albite is porphyroblastic; and also carbonaceous schist and quartzite, which are interbedded with noncarbonaceous schist and dark massive quartzite. North of the international boundary the rocks in the Hazens Notch formation extend along the strike into a terrane chiefly of quartz-sericite-albite-chlorite schist and interbedded carbonaceous zones, greenstone, and quartzite, variously referred to as the Sutton schists (Clark, 1934, p. 15-16), Sutton group (Ambrose, 1942), and schists of the Caldwell group (Cooke, 1950, p. 19-23).

\section{SCHIST, GNEISS, AND QUARTZITE}

Quartz-sericite-albite-chlorite rocks show all lithologic variations between schist, gneiss, and quartzite, depending upon the grain size and the relative proportions of platy or equidimensional minerals. They are medium to coarse grained. Layers rich in quartz alternate

\footnotetext{
${ }^{5}$ Apparent thickness, as used here, is the average distance between the upper and lower boundaries of a stratigraphic unit measured perpendicular to a plane that most nearly represents the attitude of the unit as a whole. This usage conforms with that of White and Jahns (1950, p. 190) in east-central Vermont.
}

$664349-63-3$ 
with layers rich in sericite and chlorite, and the platy minerals are oriented parallel to the layers. Lenticular aggregates of quartz parallel the schistosity, and irregular quartz veins locally cut the schistosity and contain calcite, chlorite, and albite.

Schist predominates; light-gray to faintly green quartz-sericitealbite-chlorite schist (table 2 , column 1) that locally contains albite porphyroblasts is the most common type. The schist grades imperceptibly into less abundant quartz-albite-sericite-chlorite gneiss and micaceous, slightly albitic quartzite that occur in poorly defined stratigraphic zones within the schist. The zones of gneiss and quartzite are in general parallel to the schistosity. Quartzite that is free of chlorite and albite forms rather distinct massive beds as much as 10 feet thick. These massive beds can usually be traced for only a few hundred feet along the strike. The range in relative amounts of the quartzite, as well as of the schist and gneiss, is too irregular to define mappable units.

Noncarbonaceous schist similar to that of the Jay Peak formation locally underlies and is somewhat intergradational with the Belvidere Mountain amphibolite in the Gihon River valley. This rock forms zones thicker than the zones of noncarbonaceous schist of the Hazens Notch formation, but not thick enough to be separated from the Hazens Notch formation on the geologic map of plate 1. A zone of noncarbonaceous gneiss is differentiated on the inset map.

Dark-gray to black schist and quartzite owe their color to included carbon, but in outcrop the schist is commonly rusty brown from the weathering of pyrite. The carbonaceous schist is similar in its general lithologic characteristics to the noncarbonaceous schist, but it is finer grained and more schistose; porphyroblasts of albite are commonly black owing to included carbon. The carbon content is generally less than 1 percent. The carbonaceous quartzite is commonly massive and without schistosity. The scale of interbedding of the carbonaceous zones in the schist, gneiss, and quartzite ranges from several inches to several hundred yards.

In addition to the dominant minerals quartz, sericite, albite, and chlorite, minor minerals include, in the approximate decreasing order of their abundance, epidote, sphene, calcite, magnetite, apatite, ilmenite, rutile, tourmaline, and allanite. Carbon, though less abundant than some of the other minor minerals, is the obvious cause of the dark color of the gray to black schist and quartzite. The carbon occurs as extremely fine "dusty" aggregates in micaceous layers in the schist and is disseminated as fine particles in the quartzite. Biotite and garnet, commonly microscopic and associated with coarse white mica, are rare constituents in local zones of possibly higher grade metamorphism. 
The schist and quartzite of the Hazens Notch formation are best exposed and most conveniently seen at the type locality in Hazens Notch and in cuts along Highway 105-A in the towns of Jay and Troy. Quartz-albite-sericite-chlorite gneiss, several hundred feet thick, which is near the top of the Hazens Notch formation, crops out on the west slopes of Belvidere Mountain and Tillotson Peak, and on the slopes of Haystack Mountain and Burnt Mountain south and west respectively of Hazens Notch (pl. 1, inset); it is accessible by way of the Long Trail.

\section{AMPPIBOITTE}

Amphibolite forms tabular bodies, principally of very fine grained rather massive dark-green rock interbedded chiefly with the schist and gneiss. Within the broad area mapped as Hazens Notch formation are a number of belts of amphibolite, some large enough to be distinguished on the map and others much smaller; some are only an inch or two in thickness. As mapped, the belts appear to be different units, but the detailed structure within the Hazens Notch formation has not been fully worked out, and some bodies that appear to be separate units may be the same unit structurally repeated. Some bodies of the amphibolite may even represent infolded masses of the overlying Belvidere Mountain amphibolite.

The amphibolite is composed essentially of hornblende, epidote, chlorite, actinolite, and albite; the proportion of hornblende is higher in the dark amphibolite (table 3, column 1) than in the lighter green amphibolite, which may more properly be called greenstone. Sphene, calcite, quartz, ilmenite, and pyrite are common accessory minerals, rutile and hematite less common. Garnet and biotite occur in a few places, locally as major constituents; clinozoisite occurs locally rather than epidote. Most of the minerals commonly cannot be recognized with the naked eye, but easily distinguishable porphyroblasts of albite and of red-brown garnet (almandite) occur in some places. Garnet porphyroblasts are, in part, replaced successively outward by rims of biotite and chlorite. Albite, presumably removed from the area in which the garnet developed, is segregated beyond the ghost outline of the rim of the garnet. Parallel orientation of amphibole and chlorite grains gives the rock a rude schistosity.

Amphibolite of the Hazens Notch formation is exposed at the side road 1.4 miles east-southeast of Hazens Notch; it is less accessible at other localities shown on the map (pl. 1).

\section{JAY PEAK FORMATION}

Quartz-sericite-chlorite-albite schist, quartz-sericite-albite-chlorite quartzite, and a few beds of amphibolite make up the Jay Peak formation herein named for its typical exposure on Jay Peak in the northwestern part of the town of Westfield. The general absence of 
carbonaceous interbeds distinguishes these rocks from similar types in the underlying Hazens Notch formation, with which the Jay Peak formation intergrades, and in the younger Ottauquechee formation. The apparent thickness of the Jay Peak formation at Burnt Mountain in the town of Montgomery is about 2,500 feet. The formation thins to extinction to the east and south.

The rocks of Jay Peak and the neighboring area are in the lower part of the Jay Peak formation near the axis of the Jay Peak syncline (pl. 1). Southwest of Jay Peak, down the plunge of this syncline, the Ottauquechee formation apparently succeeds the Jay Peak formation, but in the vicinity of Jay Brook and Wade Brook the upper part of the Jay Peak formation is covered by surficial deposits, so that the the zone of transition is not exposed in the trough of the syncline. The Belvidere Mountain amphibolite is apparently absent here, though it underlies much of the Ottauquechee formation to the east in the upper Missisquoi and Gihon River valleys.

It is inferred that the southward thinning of the Jay Peak formation and its absence in the east part of the region are due to lateral facies gradation into the Hazens Notch formation and Belvidere Mountain amphibolite. Insofar as the noncarbonaceous zones are concerned, this may be primarily a textural transition rather than a compositional change. The nature and existence of the transition zone cannot be shown because it would occur between rocks chiefly on opposite flanks of the Gilmore anticline, from the axial portion of which the beds involved have been eroded.

The Jay Peak formation rather closely resembles noncarbonaceous zones of quartz-sericite-chlorite-magnetite-albite schist in the eastern and upper part of the Camels Hump group in the Hyde Park quadrangle (Albee, 1957) and presumably correlates with them. These noncarbonaceous zones are discontinuous in plan and probably also in section in the Hyde Park quadrangle, which suggests that they are tongues of the Jay Peak formation that extend laterally eastward into the synchronous upper parts of the Hazens Notch formation. (See table 1.)

The Jay Peak formation is characterized by medium- to coarsegrained clean (as opposed to rusty weathering) pale-silver-green quartz-sericite-chlorite-albite rocks (table 2, column 2) that range from schist to quartzite. Schist predominates, as in the Hazens Notch formation. Lenses of granular quartz that parallel the schistosity, as well as irregular crosscutting pods and veins, are abundant. Where the rock is quartzitic, layers of mica-rich schist a fraction of an inch to several inches thick alternate with quartz-rich layers, of about the same thickness, that parallel the schistosity of the micaceous layers. This compositional layering represents bedding. 
Quartz, sericite, chlorite, porphyroblastic albite, and magnetite are distinguishable in the hand specimen. Minor minerals include, in decreasing order of abundance, ilmenite, sphene, magnetite, and apatite. Epidote, a common minor mineral of the schist, gneiss, and quartzite of the Hazens Notch formation, is very rare in the schist and quartzite of the Jay Peak formation. As in the Hazens Notch formation, biotite and garnet are also rare in the Jay Peak formation; the chemical composition of the rocks rather than the metamorphic grade is probably in general responsible for the rarity of biotite, and less generally responsible for the rarity of garnet. Interbeds of amphibolite locally attest attainment of the higher metamorphic grade that is normally responsible for the appearance of biotite and garnet.

An excellent and readily accessible exposure of the schist-quartzite assemblage of the Jay Peak formation is 2.0 miles west of Old Splatterfoot Mountain, west of a dirt road. The formation is well exposed on the summits of Jay Peak and Burnt Mountain.

Amphibolite, which occurs in a few places in the Jay Peak formation, forms tabular bodies of fine-grained rock interbedded with the schist. Beds of the amphibolite, which total possibly 100 feet in thickness, crop out on the Long Trail 0.2 mile southeast of the summit of Jay Peak. The rock at this locality is somewhat lighter green than the amphibolite in the Hazens Notch formation and borders on greenstone. A thin section of a specimen collected here contains, in decreasing order of abundance, quartz, chlorite, hornblende, epidote, albite, sphene, magnetite, and apatite. The rock ranges in texture from schistose to granular; chlorite is the principal mineral of the schistose zones, and quartz and hornblende predominate in the granular zones. Amphibolite that borders on greenstone is possibly as much as 500 feet wide at, and north of, the summit of Little Jay.

\section{BELVIDERE MOUNTAIN AMPHIBOLITE}

The Belvidere Mountain amphibolite (Keith and Bain, 1932, p. 174; Albee, 1957), at the top of the Camels Hump group, is a coarseto fine-grained hornblende-epidote-albite amphibolite; it commonly passes into underlying and overlying formations by interbedding as well as by lithic gradation. The thickest and most complete section of the Belvidere Mountain amphibolite, possibly as much as 1,000 feet thick, is at the type locality on Belvidere Mountain, near the boundary between the towns of Eden and Lowell. Structural repetition of this section makes interpretation of thickness difficult, but mapping is facilitated to some extent by a continuous zone of coarse amphibolite in the lower part of the section, and of fine amphibolite in the upper part. The coarse amphibolite is underlain by 
quartz-albite-sericite-chlorite gneiss at the top of the Hazens Notch formation, and in some places, as at Schofield Ledges a mile south of Belvidere Mountain, the amphibolite is almost imperceptibly gradational into the underlying gneiss. The formation is exposed along its strike for about $3 \frac{1}{2}$ miles south of Belvidere Mountain, where it eventually grades laterally into schists of the upper part of the Hazens Notch formation. It thins to extinction 12 miles to the northnortheast near the village of Troy. The lens of amphibolite that crosses Warner Hill southwest of the village of North Troy appears to be very nearly the same stratigraphic zone as that of the belt from Belvidere Mountain to the village of Troy.

Some of the detached masses of amphibolite that occur within the area mapped as Hazens Notch formation (pl. 1) are probably tongues and synclinal outliers of the Belvidere Mountain amphibolite, although many belong to the Hazens Notch formation. The mass of amphibolite on Tillotson Peak is a notable example. A correlation between the Belvidere Mountain amphibolite and the amphibolite mass on Tillotson is suggested by the following relations: some of the amphibolite on Tillotson Peak, particularly that near the outer margins, is coarse grained like that in the lower part of the Belvidere Mountain amphibolite; and the position relative to amphibolite of the band of quartz-albite-sericite-chlorite gneiss that wraps around the western end of the amphibolite on Tillotson Peak is similar to that of the quartz-albite-sericite-chlorite gneiss that occurs at the top of the Hazens Notch formation on Belvidere Mountain. Such a correlation implies that the gneiss and amphibolite of Tillotson Peak are in a doubly plunging syncline whose axis is overturned at the western end, as shown on the inset map of plate 1 . Without such a correlation the structure could be interpreted simply as a doubly plunging anticline, in which case the amphibolite in Tillotson Peak lies within the Hazens Notch formation.

Near Tillotson Mill and west of Schofield Ledges are lengthy belts of amphibolite that are considered to be tightly compressed synclines of Belvidere Mountain amphibolite. The belt near Tillotson Mill is separate from the main body of amphibolite; this relation is interpreted to indicate a doubly plunging syncline. The belt west of Schofield Ledges joins the main mass of the Belvidere Mountain amphibolite about a mile south of the Ledges; it is interpreted as a southward plunging syncline. Southeast of Schofield Ledges, the irregular contact between the Hazens Notch formation and the Belvidere Mountain amphibolite is probably largely an effect of folding, though considerable intertonguing and intergradation between schist and greenstone is evident in outcrop. It is possible to explain the map pattern of the amphibolite entirely on the basis of facies relationships, but it is be- 
lieved that structure plays the dominant and facies the subordinate role in determining the map pattern.

Greenstone that probably correlates with the Belvidere Mountain amphibolite occurs in the Camels Hump group in the northwestern part of the Hyde Park quadrangle (Albee, 1957). This greenstone is along the east limb of the Foot Brook syncline, which is the southwestern extension of the Jay Peak syncline of the present report (pl. 1). East of Hazens Notch, a belt of amphibolite that extends southwest toward the slopes north of Haystack Mountain may be a synclinal outlier of the Belvidere Mountain amphibolite, rather than an interbedded member of the Hazens Notch formation as interpreted on the map (pl. 1).

Compositional layers within the Belvidere Mountain amphibolite parallel its contacts and are presumably bedding; they are in turn paralleled by a rude schistosity produced by dimensional orientation of amphibole and micaceous minerals. Some of the Belvidere Mountain amphibolite is carbonaceous, thin bedded, and conglomeratic.

The amphibolite of Tillotson Peak and in the lower part of the section at Belvidere Mountain is very coarse grained, with large blades of dark-green hornblende, segregations of epidote and clinozoisite, and porphyroblasts of red-brown garnet (almandite). Microcrystalline albite is exceeded in abundance only by hornblende and epidoteclinozoisite. The amphibolite is finer grained, lighter green, and devoid of garnet south and northeast of Belvidere Mountain. These features are probably effects of a somewhat lower grade of metamorphism. The rock lacks amphibole in places northeast of Belvidere Mountam, and actinolite occurs instead of hornblende in places south of the mountain; in both areas the rock is better described as a greenstone.

The principal minerals of the amphibolite are, in decreasing order of abundance, hornblende, epidote-clinozoisite, albite, and sphene. Minor minerals include chlorite, biotite, garnet, quartz, coarse-grained white mica, actinolite, magnetite, and rutile. The greenstone is composed primarily of widely different proportions of chlorite, actinolite, epidote-clinozoisite, and albite; sphene, magnetite, rutile, quartz, and sericite are commonly present in small amounts. The lower metamorphic grade of greenstone is reflected in the absence of hornblende, garnet, and biotite, and the higher proportions of actinolite and chlorite. Column 2 of table 3 shows the estimated mode of a selected specimen of the Belvidere Mountain amphibolite.

The Belvidere Mountain amphibolite is well exposed in easily accessible surface strippings southwest of Lowell Quarry and west of Eden Quarry on the east slope of Belvidere Mountain. There is carbonaceous amphibolite at the Lowell Quarry exposure. Another 
good exposure is on Warner Hill southwest of the village of North Troy, where clinozoisite and albite are segregated in a coarse network of tectonic breccia veins.

\section{OTTAUQUECHEE FORMATION}

The Ottauquechee formation (Albee, 1957; Cady, 1956; Perry, 1927, p. $161 ; 1929$, p. 27-29) is one of the most distinctive formations in the Green Mountain region. It is characterized by black sericite-quartz phyllite with interbeds of massive rather dark-gray quartzite, all of which are carbonaceous. The formation also includes light-green quartz-sericite-chlorite phyllite that, in the area of the present study, grades into phyllitic graywacke.

A good section of the Ottauquechee formation, in which the principal lithic types are exposed, is in the gorge of the Jay Branch of the Missisquoi River, 2 miles south of the village of North Troy. West of Hadley Mountain on the town line between Eden and Lowell the apparent thickness of the Ottauquechee is about 1,500 feet. It appears thicker at other places to both the north and the south, but more extensive surficial deposits may conceal evidence of structural repetition.

The Ottauquechee formation continues northward across the international boundary as an undivided unit fitting the distribution and description of the lower part of the Mansonville slates of Clark (1934, p. 4, fig. 2). The easternmost and stratigraphically highest rocks of Clark's Mansonville slates lack the carbonaceous phyllite and quartzite characteristic of the Ottauquechee formation and are correlated with strata above the Ottauquechee, in the Stowe formation. The Canadian extension of the Ottauquechee has been included by Ambrose (1942) and Cooke (1951) in major stratigraphic units that probably correlate with those in Vermont as shown on table 1.

The Ottauquechee formation intergrades with the underlying Belvidere Mountain amphibolite and with the Hazens Notch formation where the Belvidere Mountain amphibolite is absent. In the Jay Peak syncline, 6 miles west of the main belt of outcrop, it is underlain by the Jay Peak formation. The Ottauquechee can be distinguished from the Hazens Notch formation by its greater abundance of phyllite than schist, higher content of carbon in carbonaceous zones, comparatively low albite content, and nearly complete absence of albite porphyroblasts. Albite is commonly less abundant than chlorite in these rocks, whereas it generally exceeds chlorite in the schist of the Hazens Notch formation. The different lithic types are too in timately interbedded within the Ottauquechee formation to differentiate on the geologic map (pl. 1), but they fall into four distinctive groupingscarbonaceous phyllite, carbonaceous quartzite, quartz-sericite-chlorite phyllite, and phyllitic graywacke-which will be described under 
separate headings. The graywacke is most abundant in the eastern, upper part of the Ottauquechee formation.

\section{CARBONACEOUS PHYLIITE}

The carbonaceous phyllite is a sericite-quartz rock (table 2 , column, 3 ) in which the carbonaceous material is disseminated as dustlike accumulations of microscopic particles, both in micaceous layers and along slip-cleavage planes. The phyllite grades locally into coarser grained and less even textured carbonaceous schist. Thin lightcolored layers, which are commonly less than 0.05 inch thick and which consist chiefly of microscopic grains of quartz, alternate with dark, carbonaceous layers at intervals of a fraction of an inch. The alternating layers are parallel to quartzite strata interbedded with the carbonaceous phyllite and are therefore interpreted as bedding. Sericite flakes oriented parallel to the layering produce a bedding schistosity, which is the principal schistosity of the rock except where a transecting schistosity developed from slip cleavage prevails.

In addition to dominant sericite and quartz, minor minerals, in diminishing order of abundance, are: chlorite, albite, sphene, and pyrite. The pyrite is commonly completely weathered from outcrops, and leaves cubic cavities which are generally less than one-fourth of an inch across and are bordered by zones of brown limonite stain. Carbonaceous material is generally more abundant than any of the minor minerals listed above; it cannot be resolved with the microscope and in view of the low metamorphic grade of these rocks it is probably amorphous carbon rather than graphite. The carbon does not commonly exceed 5 percent except where segregated along slip cleavage, but that amount is more than enough to color the rock black.

The carbonaceous phyllite commonly forms poor outcrops but it is well exposed in river gorges such as the one a little downstream from Big Falls on the Missisquoi River about 1.7 miles southeast of North Troy and also in the excellent section along Jay Branch. At the locality near Big Falls, lenticular beds of black carbonaceous limestone are interstratified with the carbonaceous phyllite.

\section{CaRBONACEOUS QUARTZTTE}

Dark-gray quartzite occurs in sharply defined massive beds, commonly single, that are interstratified with the carbonaceous phyllite. Some of the gray quartzite beds are as much as 20 feet thick, though many are as little as an inch thick. A faint schistosity occurs in some. The quartzite commonly contains abundant randomly oriented veins of white quartz from $\frac{1}{2}$ inch to 2 inches in width that contrast sharply with the dark rock.

The principal minerals of the carbonaceous quartzite are quartz and sericite (table 2, column 4), though sericite is commonly less $664349-63-4$ 
than 5 percent. Carbon is in thin micaceous partings and is sparsely disseminated throughout the quartzite as small dustlike specks that are abundant enough to give the dark-gray color to the rock, but not so abundant as in the carbonaceous phyllite. Other minerals, which occur in traces, include albite, calcite, chlorite, limonite, zircon, and apatite.

The carbonaceous quartzite is well exposed in the gorge of Jay Branch, 0.2 to 0.5 mile east of the road (Route 101) between Troy and North Troy, and intermittently from there north to the pastures a little southwest of North Troy. It apparently occupies a fairly well defined stratigraphic zone near the base of the Ottauquechee formation in this part of the area, although there is no evidence for continuity of a similar zone of carbonaceous quartzite south of Jay Branch.

\section{QUARTZ-SERICITE-CHLORITE PHYLITTB}

The quartz-sericite-chlorite phyllite is a fine-grained light graygreen rock, which locally weathers buff. At a few places it grades into schist, which is coarser grained and contains megascopic lenses of granular quartz. Light-colored phyllitic limestone beds occur locally. Much of the phyllite has a fine interlamination of paperthin micaceous laminae and granular laminae that are commonly less than 0.1 inch thick. These micaceous and granular laminae are seen in thin section to be predominantly of sericite and quartz, respectively. The laminae are parallel to coarser compositional layering in the Ottauquechee formation, particularly beds of sericitic quartzite, and are therefore considered to be bedding.

Bedding schistosity is commonly the principal schistosity of the phyllite that contains the fine laminae. As in the carbonaceous phyllite, the schistosity is produced by sericite flakes that are oriented parallel to the compositional layering. The principal schistosity of some of the phyllite is transverse to the bedding where the phyllite lacks alternating granular and micaceous laminae. This transverse schistosity grades into slip cleavage. The transverse schistosity and the bedding schistosity that occur within the slip-cleavage lamellae are both paralleled by microscopic lenses of granular quartz.

The principal minerals of the phyllite are quartz and sericite; chlorite and albite are much less abundant (table 2, column 5). The chlorite is commonly parallel to and interleaved with the sericite, although individual grains are locally oriented at a high angle to the sericite and the schistosity. Albite is associated with quartz in the granular layers of the laminated phyllite; only rarely does it have a porphyroblastic habit, and then only on a microscopic scale. Minor minerals include magnetite, sphene, tourmaline, limonite, apatite, 
pyrite, zircon, and iron-bearing carbonate. Where iron-bearing carbonate is present, the phyllite weathers buff.

Buff-weathered quartz-sericite-chlorite phyllite that shows fine bedding laminae crops out on the west bank of the Missisquoi River in a locality about 0.5 mile northwest of Lowell village and a little downstream from the forks of Burgess Branch and East Branch. Phyllite, in which the principal schistosity is parallel to slip cleavage rather than to bedding, crops out in the village of North Troy northwest of the Canadian Pacific Railroad bridge and west of a private driveway. Interbeds of carbonaceous phyllite are exposed east of the driveway.

\section{PHYLIITIC GRAYWACKE}

The phyllitic graywacke is a drab-weathered, gray rock with poor schistosity. It is composed (table 2, column 6 ) of poorly sorted, sand-size, angular to rounded clastic grains consisting chiefly of quartz but partly of feldspar. These clastic grains are set in a much finer grained, micaceous to granular matrix that commonly makes up 40 to 60 percent of the rock. In addition to quartz and feldspar, traces of detrital rock fragments, particularly quartzite, and more rarely slate and chert fragments, are distinguishable under the microscope. The principal minerals included in these fragments are sericite and quartz. The feldspar grains are chiefly albite, but microclineperthite, perthite, and sparse orthoclase also occur. Traces of other detrital minerals include well-rounded tourmaline and zircon.

Matrix minerals are, in decreasing order of abundance, sericite, quartz, chlorite, albite, calcite, sphene, and epidote. The outlines of original quartz and feldspar grains of the matrix have been completely obliterated. Sericite and chlorite commonly form very thin micaceous laminae that pass between and around the coarse grains and give the rock its schistosity. Fine specks of carbon in the micaceous laminae contribute to the grayness of the rock.

The phyllitic graywacke grades into the quartz-sericite-chlorite phyllite already described, in which recrystallization has obscured or destroyed the original clastic textures. Although the unsorted angular detrital grains characteristic of the graywacke fabric may not be apparent in hand specimens of the phyllite, they are commonly faintly recognizable in thin section. The phyllitic graywacke locally grades into sericitic quartzite, in which detrital grains of sand size form most of the rock and the feldspar content is much reduced. The quartzite commonly weathers light gray but is darker gray on fresh surfaces.

Both the phyllitic graywacke and the sericitic quartzite frequently include or are adjoined by beds of granule and pebble conglomerate. The phenoclasts, which are as large as 6 millimeters, are predomi- 
nantly quartz, but some are black shale and feldspar. They constitute as much as 45 percent of the rock. The quartz phenoclasts are subrounded to angular in shape and are undeformed. The coarsest grains are in beds with a high pebble content. The matrix consists of quartz, sericite, chlorite, and easily weathered iron-bearing carbonite.

Phyllitic graywacke is exposed 1.15 miles east-northeast of the highway bridge at North Troy in a ledge about 0.6 mile south of the international boundary and a little east of a dirt road. Interbedded sericitic quartzite, phyllitic graywacke, and quartz-sericite-chlorite phyllite crop out in ledges 0.4 mile southeast of the cemetery that is half a mile south of Westfield. Phyllitic graywacke and conglomerate are well exposed in a low north-trending ridge, 0.1 mile west of the Missisquoi River and 0.8 mile north of the Lowell-Westfield town line. The Knob, 1.0 mile north-northeast of Edin Mills, is a large ledge of rather massive phyllitic graywacke and associated conglomerate. The Ottauquechee formation is exposed at a few places in the Jay Peak syncline. Exposures including typical carbonaceous phyllite and quartzite are 2.5 miles due west of Old Splatterfoot Mountain.

\section{STOWE FORMATION}

The Stowe formation (Albee, 1957; Cady, 1956) is chiefly characterized by sericite-quartz-chlorite-albite schist that contains numerous lenticles of granular white quartz parallel to the schistosity. Where the rock is apparently less deformed and less metamorphosed than is normal, it is best described as sericite-quartz-chlorite-albite phyllite with well-preserved thin bedding and without granular quartz lenticles. Carbonaceous quartz-sericite-chlorite schist and phyllite is a prominent facies in the southeastern part of the area. This facies is possibly as much as 3,000 feet thick. Bedded greenstone is common in the Stowe formation, particularly in the southwestern slopes of the Lowell Mountains, where the greenstone is as little as a foot to 1,000 feet thick or more. (See pl. 1.) The greenstone is extensively and rather completely carbonatized in the southern parts of the area. Poorly defined zones of other types of rocks include phyllitic graywacke and sericitic conglomerate. The apparent thickness of the Stowe formation in the southern part of the area is about 5,000 feet. At the international boundary it is probably not more than 1,500 feet thick.

At its base, the Stowe formation intergrades with the upper part of the Ottauquechee formation, from which it can be distinguished principally by the absence of the massive dark-gray quartzite that is characteristic of the Ottauquechee. Phyllitic graywacke is locally very common along the Missisquoi River north from Lowell to the 
international boundary, particularly near the Ottauquechee formation; also the conglomeratic zones are more abundant in this area. However, in the southern part of the map area and in the Lowell Mountain anticline phyllitic graywacke is scarce or absent. A section of the Stowe formation that is relatively little repeated by folding, and that includes the greenstones and the southeastern carbonaceous facies as well as the schist and graywacke, is exposed about parallel to the road across the Lowell Mountains southeast of Lake Eden. In the northern part of the area, there is a good section of the Stowe formation showing the conglomerate zones east of the village of Troy, and another thinner section at and east of Big Falls, farther north in the town of Troy.

The main mass of the Stowe formation, in and north of the Lowell Mountains, plunges north beneath the Moretown formation at the axis of the Lowell Mountain anticline before reaching the international boundary. The narrow belt of the Stowe exposed a little east of the Missisquoi River can be traced northward, along the west limb of the Missisquoi Valley syncline and into the upper part of the Mansonville slates of Clark (1934, p. 4, fig. 2) in Quebec. Here it occupies the easternmost part of the belt mapped by Cooke (1951) as "gray quartzite and slate of the Caldwell group."

\section{SERICITE-QUARTZ-CHLORITE-ALBITE SCHIST AND PHYLITE}

The principal differences between the schist and the phyllite are due to varied structural and metamorphic effects rather than to differences in the original sedimentary rock. The schist is cut by more slip cleavage and schistosity transverse to bedding and contains more segregations of quartz in lenticles and veins than does the phyllite. Both are silver-green sericite-quartz-chlorite-albite rocks (table 2, column 7). The sericite content is generally greater than the quartz content if the quartz lenticles and veins are excluded; even if they are included, the sericite and chlorite together generally exceed the quartz. Albite, commonly fine-grained, makes up less than 15 percent of the rock. Minor minerals include sphene, ilmenite, rutile, magnetite, calcite, tourmaline, and apatite.

Quartz-sericite-chlorite-albite schist and phyllite are well exposed in roadcuts along Route 100 northwest of Lake Eden.

\section{CARBONACEOUS QUARTZ.SERICITE-CHLORITE SCHIST AND PHYLLITE}

The carbonaceous schist and phyllite are greenish-gray to black, rusty-weathered rocks that are texturally little different from those that are not carbonaceous. Schistose rather than phyllitic types are most abundant inasmuch as the zone in which the carbonaceous facies chiefly occurs is in the Lowell Mountains where the metamorphic grade appears to be a little higher. The principal minerals are quartz and 
sericite (table 2, column 8). Albite occurs locally. Carbon is about as abundant as chlorite. Accessory minerals include ilmenite, rutile, hematite, and leucoxene. There are readily accessible exposures of the carbonaceous schist and phyllite in the Lowell Mountains northeast of the Eden-Craftsbury road and at the north end of the ridge of Black Hill, south of the road junction at South Newport. Carbonaceous rocks occur in a few isolated places not shown on the map; a locality west of Farman Hill and another about 2 miles northeast of Lowell village, along LeClair Brook, are notable.

\section{GREENSTONE}

Fine-grained light-green epidote-chlorite-quartz-albite greenstone is common in the Stowe formation. The greenstone shows distinct compositional layering, although it is otherwise a rather massive granular rock. Well-defined schistosity occurs locally. Thin lightcolored layers of epidote or clinozoisite, quartz, and albite are typical. The color of the rest of the rock ranges from lighter to darker shades of green. In outcrops, the layering of greenstone is commonly emphasized by solution pits that are arranged in rows spaced at intervals of a few inches and that mark the trace on the surface of the outcrop of calcareous zones a fraction of an inch thick. Most of the calcareous zones, as well as part of the quartz in the layers, are probably relict beds of chemically precipitated carbonate and detrital quartz; these beds were probably deposited between strata that were formed of volcanic detritus. The detailed parallelisms of this layering-with bedding in adjacent schist, with major contacts between greenstone and schist, and with thin interbeds of schist within the greenstone-all support this interpretation.

The principal minerals of the greenstone are, in decreasing order of abundance, epidote-clinozoisite, chlorite, quartz, and albite (table 3, column 3). Carbonate, including calcite and ankerite, is a minor constituent that commonly makes up less than 15 percent of the rock. Locally the rock contains abundant carbonate and is indistinguishable from limestone that is weathered brown, although carbonatization probably accounts for the concentration of carbonate. Associated are numerous interbeds of highly ankeritic greenstone and of ankeritic, carbonaceous quartz-sericite phyllite.

The greenstone east of South Newport and south of Newport Center contains abundant actinolite. The abundance of actinolite is probably a results of contact metamorphic action of a pluton of the Eltey Mountain granite that crops out not far to the east of the greenstone. Some of this rock contains microscopic laths of hornblende and plagioclase that occur in a matrix of shreddy actinolite and that appear to represent relict phenocrysts in a uralitic groundmass. The hornblende is 
thus interpreted as magmatic, the actinolite (uralite) as metamorphic. Actinolite also occurs in greenstone at the south-plunging axis of the Lowell Mountain anticline, in the town of Eden, and reflects the somewhat higher metamorphic grade of the rocks of this fold.

Greenstone is well exposed in outcrops and roadcuts in Eden Notch southeast of Mount Norris, and in exposures 2.1 miles south of Newport Center a little south of Route 100.

\section{PHYLLITIC GRAYWACKE}

The phyllitic graywacke of the Stowe formation is much like that of the underlying Ottauquechee except that phenoclasts of feldspar are more common and the matrix rarely contains carbonaceous material. It is a drab-weathered, greenish-gray rock with poor schistosity and is composed (table 2, column 9) of poorly sorted, sand-size, angular to rounded clastic grains, chiefly of quartz and feldspar. These are set in a much finer grained micaceous to granular matrix, which makes up about 60 percent of the rock. Traces of detrital rock fragments, particularly quartzite and more rarely slate, are distinguishable microscopically; quartz and sericite are the principal minerals of the fragments. As in the Ottauquechee formation, the feldspar grains are chiefly albite, though microcline-perthite is also rather abundant. Traces of other detrital minerals include apatite and tourmaline. Matrix minerals are -in decreasing order of abundance-sericite, chlorite, biotite, quartz, sphene, ilmenite, and magnetite.

The phyllitic graywacke, like that of the Ottauquechee formation, frequently includes or is adjoined by beds of granule and pebble conglomerate. The phenoclasts of the conglomerate, which in some places compose more than half of the rock, are predominantly quartz. Pebbles and granules of microcline-perthite have been found in several places. The conglomerate and nearby graywacke contain grains that are more rounded and commonly better sorted than those of the bulk of the phyllitic graywacke; its matrix approaches the equigranular texture of quartzite.

The best outcrop of the phyllitic graywacke and associated conglomerate is a little east of a side road about three-fourths of a mile eastsoutheast of the village of Troy. Phyllitic graywacke is exposed eastnortheast of Troy in road cuts along Route 100. Intergradational relations between the phyllitic graywacke and quartz-sericite-chloritealbite schist and phyllite are well shown in outcrops at Big Falls, southeast of North Troy.

\section{UMBRELIA HILL FORMATION}

The Umbrella Hill formation (Albee, 1957) is composed of quartzand slate-pebble phyllitic quartz-sericite-chloritoid conglomerate and interbedded quartz-sericite-chloritoid slate and phyllite. The forma- 
tion extends north-northeast about 20 miles from the eastern part of the town of Hyde Park (about 3 miles south of the area of the present study) to the southern part of the town of Newport. The apparent thickness is locally as much as 1,000 feet.

The contact of the Umbrella Hill with the underlying Stowe formation is sharp; a small isolated mass of the phyllitic conglomerate, west of the main belt and about 2 miles south of the area of the map, rests with angular unconformity on the Stowe (Albee, 1957). In addition, the rocks beneath the Umbrella Hill are not the same from place to place; the conglomerate may overlie carbonaceous schist, noncarbonaceous schist, or greenstone units of the Stowe formation. This relation is most readily explained as unconformable discordance, but lateral facies changes in the Stowe are such that the Umbrella Hill lormation could conceivably be in contact with different facies in diflerent places without any angular discordance. The Umbrella Hill is overlain, apparently conformably, by the Moretown formation.

The best sections showing relations to overlying and underlying lormations crop out in the lower eastern slopes of the Lowell Mountains in the eastern parts of the towns of Eden and Lowell. Greenstone and quartz-sericite-chlorite schist of the Stowe formation appear to be interfolded with the Umbrella Hill formation east of Upper Diggings. A narrow strip of phyllitic conglomerate lies wholly within an area of the Stowe formation on the south slope of Black Hill at the southern extremity of the town of Newport. Although it suggests an interbed in the Stowe it, too, is possibly synclinal.

Greenstone crops out between the Umbrella Hill formation and basal slates of the Moretown formation at the northern end of the main body of the Umbrella Hill (pl. 1). C. G. Doll (oral communication, 1959) interprets this relation as due to minor faulting. Such an interpretation is suggested by the close proximity of the large band of greenstone in the Stowe formation next west of and stratigraphically beneath the Umbrella Hill. The greenstone is continuous around the north end of the Umbrella Hill formation, which termination appears to be at a diagonal shear zone. The Umbrella Hill formation does not occur between the Stowe and Moretown formations on the two limbs of the Missisquoi Valley syncline in the north-central part of the area.

Subrounded white quartz phenoclasts are the most abundant fragments in the phyllitic conglomerate, but red, yellow, and blue-gray slate fragments are common. The largest phenoclasts in most outcrops are pebbles that range from 2 to 3 inches in diameter, but quartz cobbles as much as 5 inches in diameter have been noted. The pebbles and cobbles are undeformed. The proportion of phenoclasts to matrix is quite variable. The matrix is a gray phyllite composed of quartz, sericite, and fine-grained opaque minerals, chiefly magnetite; it ranges 
in color from blue gray to light tan. Porphyroblastic plates of greenish-black chloritoid, 1 to $3 \mathrm{~mm}$ in diameter, are abundant in both the matrix and the slate pebbles. The overall chloritoid content seldom exceeds 5 percent, but much of this is concentrated in certain slate pebbles and in thin zones in the matrix.

Thin beds of greenish-yellow sericite slate (table 2, column 10), with as much as 30 percent chloritoid porphyroblasts, are interlaminated with and are partly gradational into the matrix of the phyllitic conglomerate. Thick zones of slate and phyllite, with minute chloritoid porphyroblasts, account for nearly half the thickness of the Umbrella Hill formation in some places, especially in the wide belt in which it crops out northeast of upper McLeary Brook in the eastern part of the town of Lowell. Here quartz conglomerate is most abundant in the eastern part of the belt and forms rather prominent eastward-facing escarpments.

The Umbrella Hill formation is readily accessible 2.65 miles southeast of Eden Mills, at the height of land on the road from Eden Mills to Craftsbury. It is also well exposed a little north of Ware Brook in the southern part of Newport township, where the formation is crossed by the Portland-Montreal oil pipeline.

\section{MORETOWN FORMATION}

The Moretown formation (Albee, 1957; Cady, 1956) comprises quartz-sericite-albite-chlorite granulite, quartz-sericite-chlorite phyllite and slate, and quartzite that is both sericitic and chloritic. These rocks are all interbedded and intergradational with each other and are mapped as a single unit. A separately mapped intergradational unit in the upper part of the Moretown, herein named the Coburn Hill volcanic member, includes pillow amphibolite and greenstone with interbeds of graywacke, slate, and conglomerate. This new member of the Moretown is named for the type locality in the west slope of Coburn Hill in the town of Newport.

Good sections of the Moretown formation are exposed in the east limb of the Lowell Mountain anticline, especially south of Eltey Mountain in the ridge east of Lamphear Brook in the town of Albany, and along Ware Brook in the towns of Irasburg and Newport The Coburn Hill volcanic member is east of and stratigraphically above phylliteslate of the Moretown formation, in the west slope of Coburn Hill. It is succeeded to the east (east of the map area) by more of the phyllite and slate (Doll, 1951, pl. 1). The apparent thickness of the Moretown formation south of Eltey Mountain is about 6,000 feet.

The Moretown formation grades up and out of the Umbrella Hill formation. Where the latter is absent the Moretown grades from the Stowe formation. This takes place most conspicuously by decrease 
in the relative proportion of the megascopic granular quartz lenses that characterize much of the Stowe in the vicinity of the transition into the Moretown.

The Moretown formation is stratigraphically equivalent to the Ordovician Beauceville group of Cooke (1950, p. 33-48; 1951) in Quebec, though it contains more granulite and quartzite, and less slate, than does the Beauceville. The Coburn Hill volcanic member of the Moretown is the same as the Bolton lavas of Cooke $(1950$, p. $80-81 ; 1951)$ in Quebec on Bear Mountain at the international boundary; as Ambrose (1942, 1949, 1957) has shown, these lavas are interbedded with the strata of the Beauceville. The base of the Bolton lavas in large areas north of the international boundary is lower in the section than is the base of the Coburn Hill volcanic member in Vermont. The Moretown formation correlates with all but the basal part of the Cram Hill formation as used by Doll (1951, p. 15-18) in the east limb of the Lowell Mountain anticline in the towns of Irasburg, Coventry, and Newport. The basal part of the Cram Hill as used by Doll is the Umbrella Hill formation, but the principal and remaining portion is chiefly phylliteslate. This phyllite-slate is a facies of the Moretown formation that in central Vermont is separated along strike from the type Cram Hill formation (Currier and Jahns, 1941, p. 1493-1496) by areas of granulite and quartzite that contain no phyllite or slate (Cady, 1956). Because of the intervening granulite and quartzite, identification of the phyllite-slate as the Cram Hill is not clear.

\section{QUARTZ-SERICITE-AIBITE-CHLORITE GRANUIITE}

The granulite is the most distinctive rock of the Moretown formation, owing to characteristic fine, closely spaced stripes. This socalled pinstripe (Cady, 1956) is produced by light gray-green granular layers, commonly less than an eighth of an inch thick, separated by darker colored paper-thin micaceous partings that give the rock a crude schistosity. The layers and partings of the "pinstripe" are predominantly thin beds, as shown by their parallelism with interlaminated beds of quartzite and carbonaceous phyllite-slate at the noses as well as in the limbs of folds. Secondary layers and partings, which are identical in appearance, locally transect bedding in the noses of folds. The granulite cleaves along the micaceous partings, and where the perfection of the schistosity increases, the granulite grades into phylliteslate. On the other hand, the granulite becomes massive, with little if any apparent schistosity, where the micaceous partings pinch out.

Quartz and albite are the principal minerals of the granular layers and together make up most of the rock (table 2, column 11). Small amounts of chlorite give the granular layers a faint green tinge. The micaceous partings, which commonly account for much less than a 
third of the volume of the rock, contain chiefly sericite and some chlorite and quartz. Minor minerals of the granulite are, in the decreasing order of their abundance, sphene, biotite, ilmenite, tourmaline, magnetite, apatite, epidote-clinozoisite, zircon, and leucoxene. Calcite, orthoclase, perthite, muscovite, microcline-perthite, and garnet have been found in thin sections of a few specimens.

The granulite of this area, notably the granular layers of the "pinstripe," commonly shows fine angular to rounded clastic grains that are unsorted as to size and are set in a finer grained matrix. The fabric is typical of graywacke except that the clastic grains are predominantly of silt rather than sand size and the clastic outlines of the finer grained matrix minerals are modified metamorphically, chiefly by enlargement of quartz and feldspar grains with development of a granoblastic texture. Where the grains of the protolith were apparently all smaller than silt size, as in the micaceous partings of the "pinstripe" or in phyllite-slate interbeds, none of the clastic features remain. The granulite grades into quartzite where the quartz content is increased and the quartz grains are better rounded and sorted.

The granulite is well exposed at several places: along the EdenCraftsbury road southeast of the Lowell Mountains; in a ledge southwest of the highway (Route 105) 0.75 mile northwest of Newport Center; 0.15 mile south-southwest of the end of an abandoned farm road 2.5 miles west-southwest of Newport Center; and in an area along lower Tamarack and Mineral Springs Brooks in southernmost Troy and southeastern Westfield townships. In the latter area massive brown-weathered granulite without the "pinstripe" is more common than granulite with the "pinstripe."

\section{QUARTZ-SERICITE-CHLORITE PHYLITTE-SLATE}

The phyllite-slate ranges in color from very light gray to green or black, depending upon the amount of chlorite, carbonaceous material, and magnetite present. The most abundant mineral is quartz in microscopic grains which generally makes up more than half of the rock (table 2, column 12). Sericite is everywhere present and gives a light sheen to the rocks. The chlorite content is relatively low. Carbon rarely exceeds 2 or 3 percent, but that amount is enough to color the rock black. Minor minerals include magnetite, ilmenite, and sphene. At the base of the Moretown formation chloritoid forms minute porphyroblasts in phyllite-slate that is gradational into the underlying Umbrella Hill formation.

Phyllite-slate is well exposed in the westernmost part of the town of Irasburg, where it is continuous with the Cram Hill formation as used by Doll (1951, pl. 1). Elsewhere it forms less continuous sections of phyllite and slate and is commonly interbedded with granulite and quartzite. 


\section{SERICITIC AND CHLORITIC QUARTZITE}

The granulite grades locally into quartzite. The gradation is characterized by the loss of the albite and most of the chlorite in the granular layers and by the pinching out of the micaceous partings. Nevertheless, small amounts of sericite and chlorite (table 2, column 13), as well as sphene and epidote-clinozoisite, commonly occur in the quartzite. Other minor minerals include tourmaline, biotite, ilmenite, apatite, zircon, and leucoxene. Quartz, sphene, chlorite, and epidote-clinozoisite fill tiny segregation veins.

Subangular to rounded clastic grains of quartz are commonly recognizable in thin sections of the quartzite. The clastic grains are better sorted than in the granulite, and there is less contrast between matrix and phenoclasts. The protolith of some of the thin-bedded quartzites interbedded in the phyllite-slate was probably not a clastic rock. These quartzite interbeds contain very fine grained granoblastic quartz, weather light gray to white, and resemble chert.

Quartzite crops out in the bed of Truland Brook about a mile southeast of Lowell village; most of the rock is rather massive rustyweathered quartzitic siltstone that is interbedded with fine-grained granulite. Thin interbeds of quartzite in slate, in a section with interbedded granulite, are exposed at the falls of the south fork of Beetle Brook, north of a crossroad 3 miles east-southeast of the village of Westfield. Thick interbeds of quartzite in phyllite-slate are exposed in the southwest-facing hill slopes 1.5 miles southwest of Bear Mountain, near the western border of the town of Newport.

\section{COBURN HILL VOLCANIC MEMBER}

The Coburn Hill volcanic member of the Moretown formation includes actinolite-chlorite-albite-epidote greenstone and hornblendealbite-epidote amphibolite. The metamorphic grade of these rocks is higher than that of much of the Moretown and Stowe formations to the west and may be attributed to the granite plutons emplaced in the Coburn Hill member. Interbedded with the volcanic rocks are slate, graywacke, and fine conglomerate strata.

The actinolite-chlorite-albite-epidote greenstone is a massive lightgreen commonly fine grained greenish-gray weathered rock. An ophitic ${ }^{6}$ and possibly also a microporphyritic texture can commonly be recognized in thin sections, despite metamorphic alteration. The principal minerals are actinolite, chlorite, albite, epidote-clinozoisite, and sphene (table 3, column 4). Other minerals include calcite, quartz, ankerite, magnetite, sericite, and ilmenite. The actinolite is a shredded, "motheaten," or flaky-appearing amphibole formed by uralitization of primary pyribole. The greenstone is reported to in-

\footnotetext{
${ }^{6}$ The terms ophitic and diabasic are used throughout this paper for convenience in description and without implying the species of pyribole that would be indicated by strict usage.
} 
clude phenocrystic hornblende in neighboring Quebec (Fairbairn, 1933, p. 555), which suggests that the protolith of the Coburn Hill volcanic member was a hornblende basalt, or possibly a hornblende andesite. The chemical composition of the greenstone in Quebec is very close to that of Daly's average of 198 basalts (Fairbairn, 1933, p. 556).

Greenstone that shows pillow structures crops out 0.7 mile northnortheast of Summit Siding on the Canadian Pacific Railroad, in the town of Newport. It is also abundant on Bear Mountain at the international boundary, where it interfingers with the phyllite-slate of the Moretown formation. The interfingering is chiefly an effect of folding, although stratigraphic intertonguing of the volcanic rocks with the phyllite-slates may be partly responsible for the areal pattern. Gradational contacts occur that involve apparently detrital facies of the volcanic rocks. One such contact, which is exposed 0.3 mile northnorthwest of the crossroads about 1.5 miles southeast of Bear Mountain, is between the phyllite-slate and beds of greenstone that are not large enough to show on the map. Massive graywacke and conglomerate, which are interbedded with the greenstones, crop out 0.3 mile south of the international boundary in the southwestern slope of Bear Mountain. Slate interbedded with greenstone is in the bed of a brook south of a T-intersection of roads about 2 miles southeast of Bear Mountain.

The hornblende-albite-epidote amphibolite is a massive, dense, very dark green, fine-grained, drab-weathered rock with a relict ophitic to diabasic texture like that of the greenstone. The principal minerals are hornblende, albite, epidote-clinozoisite, and sphene (table 3 , column 5); others include biotite, chlorite, quartz, ilmenite, apatite, and limonite. The most obvious effects of metamorphism in this rock appear to be saussuritization of primary calcic plagioclase to form epidote-clinozoisite and albite, and replacement of ilmenite by sphene. These products are also segregated with others in fine veins, in the approximate paragenetic sequence: chlorite, epidote-clinozoisite, biotite, quartz.

Amphibolite with pillow structure crops out 0.25 mile northeast of Center Cemetery in the town of Newport, where it is within about 500 feet of a pluton of the Eltey Mountain granite, which intrudes it; and near phyllite and slate of the Moretown formation, on the west. The pillow structure in the amphibolite at this locality suggests that the direction of the tops of beds is to the east. The eastern extent of the Coburn Hill volcanic member in this vicinity is uncertain, partly because the pluton takes the place of the volcanic rocks within the eastern boundary of the map area (pl. 1). The volcanic rocks reappear, however, about half a mile northeast and also southeast of Smith Pond, east of the area of the map. They are succeeded yet farther east, 
within 0.1 mile of the pluton, by more phyllite and slate. Amphibolite also crops out in an isolated area of the Coburn Hill volcanic member 300-500 feet west of the granite pluton on Eltey Mountain, in the town of Irasburg. This amphibolite is an ophitic-textured albite-hornblende-sphene-epidote-chlorite rock that intergrades with granoblastic epidote-hornblende-quartz-calcite-ilmenite-albite rock.

\section{SHAW MOUNTAIN FORMATTON}

The Shaw Mountain formation (Currier and Jahns, 1941, p. 14961501) crops out at and east of the eastern border of the area of the present investigation (Doll, 1951, p. 18-20, pl. 1). It is characterized by quartz conglomerate, mica phyllite of probable volcanic parentage, and crystalline limestone. The phyllite is most common. Brown specks of limonite on the weathered surface of the phyllite are distinctive. In the vicinity of Ware Brook a little east of the map area, in the town of Irasburg (Doll, 1951, p. 18-19, pl. 1), the conglomerate is in contact with the underlying Moretown formation and is succeeded by the phyllite, which is in turn overlain by the limestone. 'The Shaw Mountain formation is apparently discontinuous along the strike, although widespread surficial deposits make it difficult to determine the extent to which it is absent. It is as much as 500 feet thick in some places.

\section{QUARTZ CONGLOMERATE}

The conglomerate is made up of well-rounded pebbles and granules, chiefly of white vein quartz, in a pale greenish-white matrix of quartzsericite-chlorite phyllite. The relative proportions of matrix and phenoclasts are extremely variable. The composition of the matrix locally verges on sericitic quartzite. At a few places microscopic garnet, presumably almandite, is concentrated in the more micaceous laminae of the matrix of the conglomerate. The garnet is probably a contact-metamorphic effect of subjacent plutons of the Eltey Mountain granite. The conglomerate is well exposed at and north of Ware Brook.

\section{MICA PHYLLITE}

The phyllite, which grades downward into the matrix of the quartz conglomerate, is composed chiefly of sericite and quartz, but contains also varying lesser amounts of chlorite, biotite, albite, orthoclase, and magnetite-ilmenite. Calcite is abundant locally, particularly in zones of gradation into the overlying crystalline limestone. Like the garnet in the conglomerate, the biotite is probably a metamorphic effect of emplacement of the nearby pluton of the Eltey Mountain granite. Quartz-sericite phyllite is nearly white and weathers light tan, but phyllite containing biotite is dark owing to the color of the mica. Masses of vein quartz, with the shape of a tear drop and less than $1 \mathrm{~mm}$ in diameter, form dark protuberances in the schis- 
tosity of biotite phyllite that occurs at a locality about 0.2 mile north of Ware Brook. In thin section these features look like amygdules and suggest that the phyllite, which seems of uniform composition here, is a metemorphosed felsic lava. Elsewhere, where the phyllite is more laminated compositionally and the features that look like amygdules are not present, the protolith was possibly tuffaceous.

\section{CRYSTALLINE LIMESTONE}

The crystalline limestone is fully as varied as the phyllite as to both type and probable mode of origin. Its principal distinguishing feature is that it contains sufficient calcite to effervesce readily with weak acid. Much of the limestone is phyllitic and rusty weathered. Crinoid columnals occur in nodular masses of crystalline limestone in the zone of transition from the phyllite into the limestone. These features have been exposed in an excavation about half a mile north of Ware Brook, outside the area of plate 1. Near Ware Brook, limestone is mixed with volcanic material, some of which appears to be a highly carbonatized lava flow with amygdules of calcite.

\section{NORTHFIELD SLATE}

The Northfield slate (Currier and Jahns, 1941, p. 1501-1506) is a quartz-sericite slate (table 2, column 14) with widely spaced interbeds of siltstone and silty crystalline limestone that are a few inches thick. Minor constituents of the slate include carbon, ilmenite, porphyroblastic ankerite, and tourmaline. Quartz is more abundant than sericite in the siltstone, and calcite is commonly about as abundant as the total amount of quartz and sericite in the limestone.

The Northfield slate succeeds the underlying formations at a zone of transition that is only a few feet wide in most places. The Northfield may be distinguished from the phyllite-slate of the Moretown formation by its limestone interbeds and commonly also by its rather numerous porphyroblasts of ankerite. These are useful criteria where the Shaw Mountain formation is missing, and the Northfield immediately follows phyllite-slate of the Moretown. Near the granite plutons, the slate is metamorphosed to a hornfels that contains biotite as well as sericite.

'The Northfield slate is exposed at a place in the bed of Brighton Brook in the town of Irasburg that is downstream and east of the highway bridge (Route 58) northeast of Eltey Mountain. Here it contains some unusual interbeds of limestone several feet thick. More nearly typical are exposures along Ware Brook, about 3 miles to the northeast and a little east of the map area (Doll, 1951, pl. 1). The apparent thickness of the Northfield is at least 1,000 feet in the area of the present study. 


\section{INTRUSIVE IGNEOUS ROCKS AND ASSOCIATED ALTERATION PRODUCTS}

The intrusive igneous rocks include ultramafic rocks, lamprophyre, metagabbro, and granite. All the bodies of ultramafic rock contain appreciable but varied proportions of serpentinite; most of the bodies are also partly altered to various talcose and carbonatic rocks. The rocks adjacent to ultramafic bodies have been altered for several inches or a few feet to rocks that vary widely in composition. Contact metamorphic aureoles show adjacent to granite plutons only where the bedded rocks include mafic volcanic rocks; the contact metamorphic rocks are described in the discussion of the Coburn Hill volcanic member of the Moretown formation.

The ultramafic rocks and granite are very abundant in separate and restricted belts but are generally absent elsewhere. Metagabbro is more widespread, but not as abundant. Lamprophyre is very rare.

Modes of specimens of the intrusive igneous rocks are shown in table 4. Those of dunite and serpentinite were selected for their minimum of alteration or mixture with other types of rocks and were measured with a point counter ( 1,000 points or more per thin section).

TABLE 4.-Estimated and measured modes of the intrusive igneous rocks

[Sample 1. Measured with point counter, 9,538 points in 5 thin sections. Sample 2. Measured with point counter, 1,000 points in 1 thin section.]

\begin{tabular}{|c|c|c|c|c|c|}
\hline & 1 & 2 & 3 & 4 & 5 \\
\hline Microcline-perthite & & & & 65 & \\
\hline $\begin{array}{l}\text { Quartz } \\
\text { Albite-oligoclase }\end{array}$ & 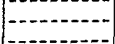 & 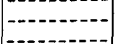 & $\mathrm{Tr}$. & $\begin{array}{r}25 \\
6\end{array}$ & \\
\hline Biotite. & $(-\cdots$ & & & $\begin{array}{l}0 \\
4\end{array}$ & $\mathrm{Tr}$ \\
\hline Chlorite & $-\ldots$ & --- & 1 & $\operatorname{Tr}$. & Tr. \\
\hline 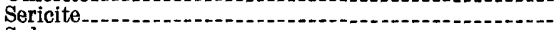 & $-\cdots$ & & & $\mathrm{Tr}$. & 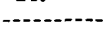 \\
\hline 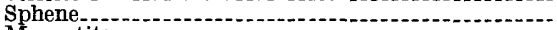 & - & & & Tr. & $-\ldots .$. \\
\hline Magnetite & - & 6 & & $\mathrm{Tr}$. & $-\cdots$ \\
\hline Clinozoisite. & - & - & 55 & $-\cdots-n$ & --- \\
\hline Hornblende & & - & 40 & 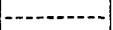 & $-\cdots$ \\
\hline Antigorite & 13 & 94 & $-\ldots-2 .-1$ &.--- & --- \\
\hline Carbonate. & 86 & & -+ & 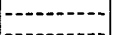 & $-\cdots$ \\
\hline Chromite-magnetite & & $-\cdots$ & -- & 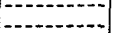 & $-\cdots$ \\
\hline Brucite $_{-}$ & $<1$ & -1 & - & 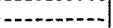 & - n \\
\hline Augite. & 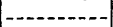 & $-\ldots$ & $-\cdots$ & $----1--$ & 65 \\
\hline Analcite. & --- & $-\cdots$ & $-\cdots$ & $-\cdots$ & 5 \\
\hline Titanomagnetite &.-- & -.......... & -- & -- & \\
\hline Calcite & --- & 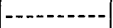 & -- & -.......... & \\
\hline $\begin{array}{l}\text { Barkevikite } \\
\text { Nepheline }\end{array}$ & -- & $---1-n-1$ & $-\cdots$ & -n-n-n & $\mathrm{Tr}$ \\
\hline Leucoxene & -- & $-\cdots$ & -- & 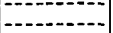 & Tr. \\
\hline
\end{tabular}

Explanation

Ultramafic rocks:

1. Dunite (AV-248-A, B, C, D, E), northeast edge of C-area quarry, about 0.1 mile south of the southeast end of the Lowell quarry.

2. Serpentinite (AV-243), near southeast end of Lowell Quarry.

Metagabbro:

3. Clinozoisite-hornblende-albite-sphene metagabbro (AA-2150) 0.06 mile S. $30^{\circ}$ E. of northwest summit of Leland Hill, Lowell.

Eltey Mountain granite:

4. Biotite (potassic) granite (AC-902) 0.9 mile S. $45^{\circ} \mathrm{W}$. of Center Cemetery, Newport.

5. Fourchite (AC-1235) 1.95 miles S. $10^{\circ}$ E. of street triangle in North Troy. 
The mode of dunite is a weighted average of five thin sections. 'The modes of the metagabbro, of the Eltey Mountain granite, and of the lamprophyre were estimated by using comparison charts for visual estimation of percentage composition (Terry and Chilingar, 1955). The specimen of metagabbro was chosen for the good preservation of its igneous texture, which is ophitic in this case, and because of the character of its contained hornblende. This hornblende is probably a relict of magmatic crystallization: it is bladed rather than fibrous, and the effects of progressive regional metamorphism in the vicinity indicate a metamorphic intensity below that necessary to have produced metamorphic hornblende. The specimen of granite chosen for modal estimate most nearly approaches the order of abundance of minerals in 10 geographically representitive thin sections. The specimen of lamprophyre is from one of three known outcrops in the map area.

\section{ULTRAMAFIC AND ASSOCIATED ROCKS}

\section{DISTRIBUTION}

The ultramafic rocks include dunite, peridotite, and serpentinite, and their alteration products, which are talc-carbonate rock, carbonate rock, and steatite. They form tabular, lenticular, or pod-shaped plutons that are a few hundred feet to as much as 3,000 feet thick and may possibly be as much as 5 miles long. The plutons approach parallelism with the schistosity and, commonly, also with the bedding of enclosing metamorphosed sedimentary and volcanic rocks. Dunite and peridotite are most abundant in the central parts of the plutons; the serpentinite occurs near the borders or makes up the whole of some of the smaller plutons. Talc-carbonate rock is distributed irregularly; steatite is nearly all at the margins of the plutons. Both are absent in some bodies. Dunite, peridotite, and serpentinite are intimately intergradational at the scale of both outcrops and thin sections. 'The serpentinite contains relict grains of olivine and masses of dunite, which show its derivation by alteration of the dunite. Dunite and peridotite, which are more resistant to weathering and erosion than the serpentinite, form hills; whereas serpentinite crops out along lower slopes or underlies surficial deposits that fill valley bottoms.

Dunite, peridotite, and serpentinite are mapped as one because of their complex intergradational relations. Talc-carbonate rock and steatite have been distinguished on plate 1 as a single map unit in a few places where exposure is adequate and their relations are relatively simple. Carbonate forms mappable units in two plutons: one is about 2 miles southeast of Belvidere Mountain and the other, a thin sill-like mass about $2 \frac{1}{2}$ miles long, is northeast of the village of Troy. Many of the contacts between plutons and adjoining rocks have been located by magnetometer surveys, as well as by drilling, done by the

$664-349-63-6$ 
Vermont Asbestos Mines Division of the Ruberoid Company. Such physical exploration is necessary because the serpentinite at the outer margins of the ultramafic bodies is covered by surficial deposits, everywhere except in mines and prospects. Two ultramafic plutons are mapped entirely from magnetometer surveys. One of these plutons is a mile southeast of the summit of Browns Ledges in the northern part of the town of Lowell and the other is 1.5 miles west-northwest of Lowell village.

The ultramafic plutons are enclosed by shells that consist either of antigorite-chlorite rock and calc-silicate rock, or of nearly monomineralic chlorite rock (fig. 2). The calc-silicate zone and associated antigorite-chlorite zone are most extensively developed where the country rock is amphibolite, but they are also prominent in some places where quartz-sericite-albite-chlorite schist and gneiss adjoin the plutons. The chlorite rock ("blackwall") appears to be restricted principally to places in which the calc-silicate rock is absent. It is invariably succeeded inwardly by steatite a few inches to a few feet thick.

\section{LITHOLOGIC DESCRIPTION}

DUNITE

Unaltered dunite is composed almost entirely of olivine, though a little chromite and magnetite are present. Pyroxene is generally rare but locally composes 1 to 5 percent of the rock. Most specimens are partly altered and contain antigorite (table 4, column 1). The rock is commonly massive and olive green to dark green; the weathered surface is buff to reddish brown and pebbly grained. The grains of olivine are subequant in shape, predominantly 0.5 to $2.0 \mathrm{~mm}$ in size, and show mosaic texture. The diameters of a few crystals are as great as $5 \mathrm{~cm}$. The large crystals locally show incipient development of a mosaic pattern like that of the fine-grained olivine, especially near their borders. This pattern is marked by slight differences in optical orientation of subequant, grainlike units of the large crystals. These relations indicate that at least some of, and possibly all, the mosaic pattern of the dunite is cataclastic in origin.

Most of the dunite is layered. The layering consists chiefly of alternating layers of serpentinite and dunite, but in some places it is marked by differences in content of magnetite and of pyroxene. Serpentinite shows a weathered surface of light-greenish-gray bands in contrast to the brown weathered surface of the dunite. Layers containing different proportions of magnetite and pyroxene are distinguished by differences in texture and color. A blocky, rectangular fracture pattern characterizes the dunite.

Dunite that is partly altered to serpentinite contains, in general order of decreasing abundance, olivine, antigorite, chromite, magnetite, chrysotile, chromian magnetite, brucite, chlorite, carbonates, 

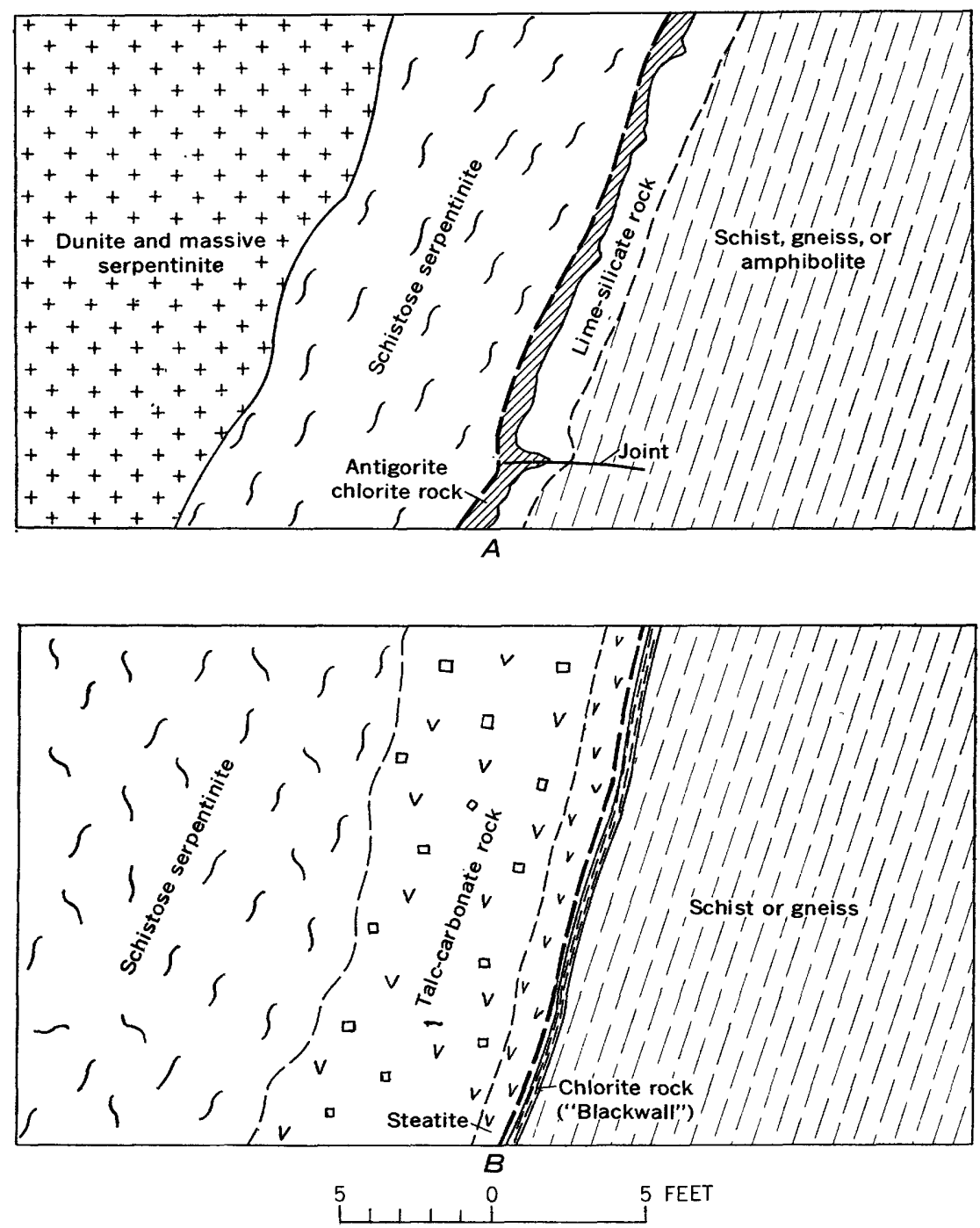

Fioure 2.--Diagrammatic sections illustrating the two principal types of zonal relations at the contacts of ultramafic plutons. $A$. Zonation of calc-silicate rock and antigorite-chlorite rock; $B$. Zonation of chlorite rock ("blackwall") and steatite. Heavy broken line marks inferred position of original contact of the intrusive rock.

and pyrite. A few scattered segregations of magnetite appear to be pseudomorphic after pyroxene. Chromite forms phenocrysts and anhedral grains that have translucent reddish-brown cores and opaque rims that are separated from the cores by irregular, wavy boundaries. It is inferred on the basis of optical properties and genetic association that the transparent cores are magmatic magnesian chromite and that the opaque rims are chronian magnetite of replacement origin. 
Most of the other minerals are associated with antigorite in serpentinite layers in altered dunite. "Dusty" aggregates of magnetite, some of which are accretionary on the chromian magnetite, are common.

Altered dunite commonly appears "motheaten" in relation to the encroaching serpentine minerals. The mutual boundaries of olivine and antigorite are extremely intricate and the texture of the antigorite is characteristically "felted." In other specimens the olivine shows an "exploded bomb" pattern in thin section. This pattern is characterized by relict central zones of unaltered olivine that are separated by rather wide and sharply bounded intersecting zones chiefly of antigorite. On a megascopic scale the central zones of unaltered olivine form the body of polyhedral blocks that are separated by sharply defined zones containing chiefly antigorite.

Dunite is best exposed in Browns Ledges 2 miles north of the village of Lowell. The brown-weathered dunite crops out boldly in steep cliffs on the south slope of the ledges. Dunite is well exposed a little west and northwest of Lowell village. Pyroxene layers are rather common in the dunite at both these localities.

\section{PERIDOTITE}

The peridotite is relatively uncommon in the region. It forms layers a few inches to a foot or two thick in dunite. Like the dunite, it is partly altered to serpentinite; none was found that was little enough altered to yield a significant mode. It is as massive as the dunite but is coarser textured. The coarse texture is chiefly a reflection of relatively large grains of pyroxene, many of which are an eighth of an inch and some one-fourth of an inch in diameter. On weathered surfaces the peridotite is deeply pitted; the pyroxene grains are leached from the rock, thus the relatively coarse texture is emphasized. As in the dunite, the weathered surface varies from buff or reddish brown to light grayish green, depending upon the degree of serpentinization. The textural relations of the olivine are the same as in the dunite. The habit of the pyroxene is phenocrystic with respect to the olivine.

The principal minerals of the peridotite are olivine and clinopyroxene except where serpentinization has progressed to the point that antigorite predominates. The proportion of clinopyroxene is variable, and all gradations from pure olivine dunite and pyroxenebearing dunite to peridotite are found; rarely does pyroxene exceed 10 to 15 percent. Other minerals are essentially the same as in dunite, and include chiefly chromite, magnetite, and chromian magnetite in unaltered rock; as well as chlorite, antigorite, and chrysotile in the partially serpentinized rock. 
Layers of peridotite in dunite are exposed on the east slope of the center knoll of Browns Ledges and at a locality 0.3 mile west of the $Y$ intersection in the street at the center of Lowell village.

SERPENTINITE

Four types of occurrence of serpentinite are recognized. These are: (a) massive serpentinite in which serpentinization of the dunite and peridotite is pervasive, and not directly related to fractures and shears; (b) serpentinite that borders fractures and veins; (c) serpentine and related minerals in veins; and (d) schistose serpentinite that is completely sheared throughout, on a microscopic as well as megascopic scale. All four types have a few features in common; the rock is fine grained, of various shades of green for the most part, and weathered to rather smoothly rounded light-greenish-gray surfaces. The weathered surface is nearly white where soil has been recently removed, as in the mine strippings. Antigorite is the principal mineral (table 4, column 2) and the only essential mineral. Other minerals common to the four types of occurrence, outlined above, are: magnetite, carbonate, chrysotile, brucite, and talc.

The massive serpentinite, which forms the principal natural exposures, is recognized chiefly by its light gray-green weathered surfaces. It occurs either as layers or as irregular patches in dunite or peridotite, or in some places as whole outcrops. It is a dark-green antigorite-magnetite-carbonate-chrysotile-brucite rock with locally a few relicts of olivine, chromite, and more rarely pyroxene. Antigorite is the principal mineral; in thin section, under crossed nicols, it characteristically shows either a felted fabric or the pattern of galvanized iron. Much of the rock that is identified as massive serpentinite in the field, chiefly by its light-colored weathered surface, contains abundant remnants of olivine and therefore is not completely altered to serpentinite. Randomly oriented antigorite partly replacing olivine and sprinkled with dustlike aggregates of magnetite, makes up the typical specimen. As in dunite, translucent cores of chromite grains are replaced by rims of chromian magnetite. Surrounding the chromian magnetite are commonly thin shells of accretionary magnetite that are irregular and jagged in detail and are made up of tiny grains. These are succeeded outward by reaction zones of chlorite, which are succeeded in turn by zones of antigorite that has unusually strong abnormal blue birefringence. This birefringence suggests aluminous antigorite. Some massive serpentinite at the Lowell Quarry was found to contain 5 to 10 percent carbon.

Serpentinite at the borders of fractures and veins forms replacement zones an inch or so wide. The zones are adjoined outward at characteristically abrupt transitions by unaltered dunite or massive serpentinite. The serpentinite of the replacement zones is much like the massive serpentinite except for its distribution, which reflects the 
influence of the veins and fractures as channels for the water necessary for serpentinization.

The veins contain most of the minerals that occur in the adjoining serpentinite. The antigorite of the veins is commonly light apple green instead of dark green inasmuch as it contains no magnetite. The magnetite is commonly segregated in portions of the veins. A waxy-appearing yellowish serpentine mineral also occurs; it is probably antigorite. Both cross- and slip-fiber chrysotile occur in these veins. Typical cross-fiber veins are best developed in the rectangular tensionfracture systems in massive dunite. Such veins are as much as threefourths of an inch wide in some places. The width of the cross-fiber veins and the width of the serpentinite zones that border them tend to be directly proportional to one another, but the relation is variable and many exceptions occur. The chrysotile veins commonly cut other vein minerals that are present, and magnetite is concentrated at the centers of the chrysotile veins. These vein and wallrock relations are believed to demonstrate that water in tiny fractures and fissures reacted with material in the adjacent walls, and that excess material from the reaction was selectively segregated in the open or incipient fissures. Similar views have been expressed in studies of asbestos deposits in Quebec (Cooke, 1937, p. 125-133; Riordon, 1955, p. 78-79). So-called ribbon veins-closely spaced parallel cross-fiber veins-also occur in dunite. The fiber in slip-fiber veins is commonly oblique to the vein wall and has apparently become oblique through shear during and after initial development as cross fiber. The slip fiber, which at first sight appears minutely disseminated, occurs in closely spaced thin veins that are about parallel to the schistosity of enclosing schistose serpentinite.

Fractured, sheared, and schistose serpentinite occurs chiefly in the outer zones of the plutons, near the contacts, where it is exposed chiefly in artificial openings. The random fabric of massive serpentinite and commonly all relicts of olivine and chromite are obliterated. Antigorite, chrysotile, brucite, talc, and chlorite contribute to a semischistose fabric in which the platy or foliate minerals vary in orientation from subparallel to diverse. Magnetite and carbonate, as well as chrysotile, brucite, and talc are segregated in shear zones that range from microscopic size to several feet across. Such rock is particularly well developed in the Lowell Quarry, which is near the east foot of Belvidere Mountain and is the principal source of chrysotile asbestos there. At this quarry antigorite commonly makes up more than 85 percent of the rock. Magnetite, carbonate, brucite, chlorite, and chrysotile occur as minor minerals.

The most abundant exposures of serpentinite are in the eastern belt of ultramafic rocks, which intrude the easternmost part of the Stowe 
formation of the west limb of the Missisquoi Valley syncline. Massive serpentinite may be found in all of the ultramafic plutons. Layering of massive serpentinite in dunite is well developed at Browns Ledges 2 miles north of Lowell village and in the quarries in the vicinity of Belvidere Mountain. Serpentine veins and the serpentinite that borders these veins, in dunite and massive serpentinite, are exposed in all of the quarries near Belvidere Mountain. The sheared and schistose serpentinite is very poorly exposed, except in artificial openings as at the Lowell Quarry. This is chiefly because it has failed to resist weathering and erosion and therefore occurs at relatively low altitudes where it is likely to be thickly covered by surficial deposits.

\section{CALC-SILICATE ROCK}

The calc-silicate rock adjoining ultramafic plutons is a buff-weathered, dense, massive, but locally vuggy rock. It occupies zones that are 6 inches to as much as 2 or 3 feet thick (fig. $2, A$ ) just outside the contacts of the ultramafic plutons, or it adjoins antigorite-chlorite rock that has replaced some of the wall rock next to the plutons, including the calc-silicate rock. The characteristic minerals of the calc-silicate rock are diopside, clinozoisite, grossularite, and vesuvianite; other minerals include sphene, chlorite, zoisite, biotite, albite, magnetite, graphite, apatite, and uvarovite. Vesuvianite, grossularite, and diopside are commonly porphyroblastic, with euhedral to anhedral outlines. The other constituents form a groundmass of finer anhedral grains. Various sulfide minerals, including bornite, chalcopyrite, pyrite, and chalcocite, were noted in the calc-silicate rock at the Lowell Quarry. Hydromagnesite(?), dolomite, prehnite, stilbite, calcite, and siderite have also been noted. Artinite and pyroaurite have been identified in this quarry (Frondel, 1946). Vugs that contain large crystals of diopside, grossularite, and vesuvianite have been a remarkable feature of the Lowell Quarry; particularly noteworthy are vugs of these minerals that occurred in a large median septum that is now largely removed.

Calc-silicate rock grades outward from near the margins of the ultramafic plutons with loss of the characteristic minerals. At the Lowell Quarry the most common transition is to Belvidere Mountain amphibolite. The amphibolite contains abundant hornblende, and clinozoisite that, on the basis of optical properties, is inferred to be a variety lower in iron than that of the calc-silicate zone. Where calcsilicate rock grades into carbonaceous amphibolite, it may contain local concentrations of carbon. On the northeast side of the pluton at the Lowell Quarry, the calc-silicate rock is developed in carbonaceous quartz-sericite-albite-chlorite schist of the Hazens Notch formation.

Calc-silicate rock has been found chiefly in the Belvidere Mountain area where the contacts of the ultramafic plutons are well exposed by 
quarrying operations. It has also been found at the pluton southeast of the village of 'Troy. There it occurs in a septum that crops out in the west slope of a hill 1.3 miles east-southeast of the road intersection in the village of Westfield.

ANTIGORITE-CHLORITE ROCK

Intergrowths of antigorite and chlorite, in various proportions, form veins and irregular replacements in the wallrock within a few inches of the ultramafic plutons (fig. 2, $A$ ). Near the contacts of the plutons the antigorite-chlorite rock contains larger amounts of antigorite than chlorite, but outward from the contacts the antigorite decreases and in a few places is absent. The wallrock that is commonly replaced by antigorite-chlorite rock is calc-silicate rock, though this is not everywhere true. Contacts between antigorite-chlorite rock and calcsilicate rock are generally sharp and, in many places, deeply embay the calc-silicate rock. The outlines of planar features that cross the embayments of antigorite-chlorite rock and correspond to layering in the calc-silicate rocks demonstrate volume-for-volume replacement. Antigorite-chlorite rock extends several feet outward in shear zones that cut across the contacts of the plutons.

The antigorite-chlorite rock is a dense, very dark blue-green, massive rock that is entirely free of olivine, chromite, and pyroxene; small amounts of epidote, chiefly clinozoisite, and sphene, ilmenite, carbon, apatite, and, rarely, diopside survive as relicts of the replaced wallrock. The antigorite and chlorite form a felted and interlocking matrix in which the granular constituents are unevenly dispersed. About the only place this rock can be seen is in the asbestos quarries, where it has been well exposed by stripping and washing of the bedrock. Here, where the cleaned surfaces are exposed, its dark color contrasts sharply with both the buff-colored calc-silicate rock which adjoins it on the side away from the plutons, and the lighter green, commonly schistose serpentinite with which it is in contact at the walls of the plutons. In quarrying, the serpentinite separates at the contact of the pluton, and the inner surface of the antigorite-chlorite rock is extensively exposed in the quarry walls.

Carbon is concentrated in antigorite-chlorite rock in shears, fractures, and faults that extend a few inches to many feet out beyond the limits of the pluton into calc-silicate rock or unaltered country rock.

The field relations of the antigorite-chlorite rock are well shown at the southeast end of the Lowell Quarry.

TALC-CARBONATE ROCK

Irregular zones that contain mixtures of talc and magnesite occur within the ultramafic plutons. The typical talc-carbonate rock of these zones is rather massive, although it is commonly cut by cross 
shears that extend into the adjacent serpentinite and are relict structures of the serpentinite. Relatively dark magnesite grains 1 to $2 \mathrm{~mm}$ across are set in a white matrix of talc. As a result the fresh rock appears gray. Outcrop surfaces commonly are stained brown by the weathered magnesite. The presence of talc makes the rock soft compared to ordinary rocks and the point of a pick can be driven into it. Minerals other than talc and magnesite (such as antigorite and magnetite) occur in relatively small quantities. The talc-carbonate zone occurs immediately within, and is intergradational with, the steatite zone, where chlorite and steatite zones are present. The talc consists of shredded particles diversely oriented, or with a rude dimensional parallelism, in both talc-carbonate rock and steatite. Carbonate forms irregular grains and masses dispersed through the matrix of talc. Magnetite occurs as sparse grains and dustlike particles.

The talc-carbonate zone varies from a foot or so to hundreds of feet in thickness in the various ultramafic plutons. At some places, notably in the long pluton near the eastern border of the Stowe formation in the town of Troy, the thickness exceeds 1,000 feet and includes the full width of the pluton. Irregular masses of serpentinite occur within the talc-carbonate rock in this long pluton. The larger bodies of talccarbonate rock are distinguished from the other ultramafic rocks on the map (pl. 1). On Belvidere Mountain near the Eden Quarry, diamonddrill holes penetrate more than 250 feet of talc-carbonate rock, some of which is separated from the contacts of the pluton by intervening serpentinite. At other places, as on the northeast side of the large pluton on the east slope of Belvidere Mountain, the talc-carbonate rock extends outward to the contacts. The talc-bearing ultramafic plutons northeast of the Belvidere Mountain area are characterized largely by successive zones of steatite and talc-carbonate rock inward from an outlying shell of chlorite rock. Talc-carbonate rock rarely occurs in ultramafic plutons covered by outlying shells of calc-silicate rock.

The most accessible exposures of talc-carbonate rock are north and south of the highway (Route 100) about a mile east-northeast of the village of Troy. The most extensive are south of Lilly Brook, 1.6 miles southeast of the village of Westfield.

CARBONATE ROCK

The carbonate rock is composed chiefly of magnesite and quartz; it is medium to fine grained, cream to buff colored on fresh surfaces, weathers brown, and strikingly retains the macrosopic appearance of serpentinite. In thin section the rock shows a sutured mosaic pattern. This rock has the same general zonal relations as talccarbonate rock and intergrades with it; it is probably succeeded outward in some places by steatite and chlorite rock zones. The largest 
body of carbonate rock known in the area is about 2 miles southeast of Belvidere Mountain (pl. 1). Another body of carbonate rock, which contains xenoliths of chlorite rock, forms a tabular unit 100 feet thick near the base of the Stowe formation northeast of Troy village; it is well exposed in the pasture that is 0.3 mile east of the village of Troy and also 0.1 mile east of Phelps Falls.

STEATITE

The rock of the steatite zone is composed chiefly of talc that is generally massive, though locally it may be flaky or schistose. The fresh rock is very light green, but where it is bruised or crushed its powder is white and if rubbed between thumb and finger is characteristically slippery. The steatite zone is commonly a few inches and rarely more than a foot thick (fig. $2 B$ ). It is extremely thin or absent in many places. In such places the chlorite rock is also thin or missing, and calc-silicate rock generally is well developed.

The steatite zone locally contains tremolite, magnetite, chlorite, and sphene, in addition to talc. These minerals tend to occur very near the outer margin of the steatite zone. They are next to the chlorite rock zone, and are probably relicts or alteration products of minerals of the country rock adjacent to the contacts of the plutons. Therefore, the steatite zone bridges the intrusive contact but is chiefly within the pluton.

The steatite zone is rarely seen in the field because of the extremely low resistance of talc to mechanical weathering and erosion. Moreover, the recovery of steatite in diamond-drill cores is poor and, although some talcose rock is commonly recovered, the cores rarely show the full thickness of the steatite zone. The best place to see steatite is where the surficial deposits have been stripped from bedrock near the asbestos quarries; a good exposure of this sort is in the northeast wall of the Lowell Quarry. A little steatite can normally be found by diligent search at borders of plutons that are exposed on hill and mountain slopes, away from coverings af alluvial deposits. Readily accessible exposures of steatite at the borders of a serpentinite mass occur in Jay Branch, on the south bank of the stream, about 800 feet southeast of the road bridge on the road (Route 101) between Troy and North Troy.

CHLORITE ROCK

Chlorite rock is a fine-grained and dense, faintly phyllitic dark-green rock composed of scaly and shredded particles that vary in arrangement from diverse to subparallel. It forms a "skin" or "rind" around the ultramafic plutons adjacent to marginal zones of steatite and talccarbonate rock (fig. $2 B$ ). The chlorite-rock zone is normally a few inches to a foot or two thick and is on the outer or country-rock side of the contact of the pluton. It is commonly called "blackwall" 
by talc miners because of its color and relations to the steatite and talc-carbonate rock.

Chlorite is the essential mineral of this zone. Biotite occurs locally. Other minerals are in transitional facies that blend with rocks of adjoining zones. Among these is albite; it is most abundant at the outer edges of the chlorite-rock zone. Magnetite, ilmenite (commonly altered to sphene), zircon, and apatite are at least in part relict minerals of the unaltered wallrock such as occurs outside of the chlorite-rock zone. Tremolite occurs in the chlorite-rock zone chiefly where the wallrock contains mafic constituents; tremolite is therefore a feature of chlorite rock adjacent to greenstone or amphibolite, rather than to schist. Finely disseminated talc is mixed with the chlorite in the inner border of the chlorite-rock zone and causes the rock there to feel soapy.

The chlorite-rock zone is very rarely seen in other than artificial exposures such as strippings, quarries, or drill cores, because its rocks as well as rocks of neighboring zones within the plutons are easily weathered and eroded and therefore are more generally covered with surficial deposits. Typical chlorite rock was recovered in the cores from 7 out of 9 diamond-drill holes that pierce contacts of the ultramafic plutons in the belt from Leland Hill in the town of Lowell north to the international boundary. Chlorite rocks were cored at several places: in the hill near the north end of the large pluton northeast of Troy village; near the south end of the pluton east of Westfield village; in the southern part and at the south end of the pluton in southeastern Westfield and northern Lowell townships; in the southern part of the pluton east of Lowell village; and on Leland Hill at the southwestern edge of the pluton west of Lowell village. The chlorite-rock zone has not been identified, where calc-silicate rock forms the wall in the quarry exposures, or in drill cores in the vicinity of Belvidere Mountain. Chlorite rock does adjoin steatite, however, at the border of a small pluton of serpentinite that is a little northeast of the main ultramafic pluton at the Lowell Quarry. The small pluton has no calc-silicate shell whereas the main pluton appears to be nearly surrounded by one. Like the steatite zone, small exposures of the chlorite-rock zone occur at the contacts of most of the better exposed plutons.

\section{GENETIC RELATIONSHIPS}

The metamorphic condition of the adjacent country rock indicates that the ultramafic rocks were emplaced at relatively low temperatures that were appreciably below possible magmatic temperatures of such rocks. (See Bowen and Tuttle, 1949, p. 452-453.) Cataclastic texture in the dunite implies tectonic transport of the crystalline masses. Extensive tectonic transport in the solid state is indicated 
by shear polyhedrons in sheared and schistose serpentinite here and elsewhere in Vermont (Chidester, 1962, p. 71, 88-89; Chidester, Billings, and Cady, 1951, p. 7-8). The dunite and peridotite are considered to have accumulated by fractional crystallization of a complex magma from which the mafic volcanic rocks of the region were also derived. Derivation by refusion of a peridotite substratum is a possible, perhaps equally plausible, alternative. The complex relations of the different types of serpentinite indicate that serpentinization was a complicated process. Formation of serpentine veins (including asbestos) and of massive serpentinite was generally earlier than the formation of the sheared serpentinite. The necessary water may have been deuteric, or may have been derived from other magmatic sources or from enclosing sedimentary rocks. The water that was necessary for sheared and schistose serpentinite was probably derived from enclosing sedimentary rocks during tectonic transport of the serpentinite (Chidester, 1962, p. 88-89).

Dunite and peridotite seem likely to have retained more magmatic heat than serpentinite bodies, which are inferred to have been transported farther tectonically; therefore, the association of calc-silicate rock with ultramafic plutons that contain considerable dunite and peridotite suggests that the calc-silicate rock and associated antigorite-chlorite rock are of contact metamorphic orgin. Thermal metamorphism may have been aided by the lowering of the chemical potential (partial pressure) of water at the contact of the pluton, because of the desiccating effect of the olivine in the plutons. (See Thompson, 1955, p. 89-92, 98-99.) The desiccating effect may have predominated over the thermal effect, even to the extent that no magmatic heat was required.

Metasomatic addition of material varied from slight or negligible in calc-silicate rock formed from amphibolite to considerable in that formed from albite schist and gneiss; addition of calcium and magnesium was required in the altera tion of the schist and gneiss to calc-silicate rock. Where the wallrock contained carbon, the carbon was "flushed out" and concentrated at the outer margins of the calc-silicate zone. The persistent zonal sequence of: (a) calc-silicate rock; (b) antigoritechlorite rock which replaces it; and (c) ultramafic pluton, indicates that the three are genetically related. Addition of magnesium was required to form the antigorite-chlorite rock; the magnesium may have been expelled from the ultramafic rocks during the episode of serpentinization responsible for the vein serpentine and the massive serpentinite.

Talc-carbonate rock and carbonate rock in ultramafic plutons are essentially carbonatized serpentinite and dunite, and were formed by metasomatic addition of carbon dioxide during regional metamorphism 
(Chidester, 1962, p. 91-124). Carbonate rock without any talc appears to be the end-stage product of the process. The general absence of talc-carbonate rock and carbonate rock at the margins of plutons bordered by calc-silicate rock suggests that the shell of calc-silicate rock antedated the carbonatization and may have physically obstructed ingress of carbon dioxide, except along tabular or irregular transecting zones that appear to be shear zones or faults. The prevalence of talc-carbonate rock at the margins of plutons lacking shells of calc-silicate rock supports this inference.

Steatite and chlorite rock ("blackwall") were formed congenetically by local metasomatic exchange (metamorphic differentiation) between serpentinite and enclosing siliceous country rocks. This exchange took place concomitantly with carbon dioxide metasomatism, so that talc-carbonate rock and steatite generally form successive zones around a central core of serpentinite. Metamorphic differentiation took place by the movement of magnesium and water outward from the developing steatite zone to the chlorite-rock zone simultaneously with the movement of silica into the steatite zone from the developing chlorite rock zone and from adjacent country rock. Where the bordering country rock was albitic, albite from the chlorite-rock zone was concentrated at the outer margins of the zone (Chidester, 1962, p. 64$65,124)$. The general absence of steatite from the margins of ultramafic plutons enclosed by shells of calc-silicate rock suggests that the calc-silicate rock may have effectively armored the serpentinite so as to prevent chemical interchange between it and the enclosing country rocks, thus blocking the chlorite-steatite reaction. Presence of the calc-silicate rock may have further inhibited this reaction by preventing carbon dioxide metasomatism of the serpentinite, thereby depriving the reaction of the possible triggering effect of the metasomatism (Chidester, 1962, p. 120).

\section{METAGABBRO}

The metagabbro is a hornblende-clinozoisite-albite-quartz-sphenechlorite rock that forms sills and nearly concordant dikes a few inches to more than 100 feet thick. The rock is commonly massive, rather dense, very dark green, and is weathered to drab rusty colors. Mineral grains are indistinguishable with the naked eye, except locally where light-colored grains are more abundant than average. Where this occurs the rock is mottled green and white, and resembles diorite. The metagabbro is distinguished in the field by its generally coarser texture and local mottling from the weathered, rusty-colored granulite and quartzite of the Moretown formation, into which it has commonly intruded.

A relict ophitic texture is commonly recognizable in thin sections of fine-grained rock. It is shown by randomly oriented, subhedral 
grains of hornblende that are in mutual contact and that enclose interstitial, also randomly oriented, oblong aggregates of clinozoisite and albite (locally oligoclase or andesine). The hornblende gives the rock its dark-green color, and the clinozoisite accounts for the white mottling of the coarse-grained phases of the rock. Quartz, like the clinozoisite, is commonly interstitial to the pervading hornblende. Sphene, chlorite, and actinolite locally replace the hornblende. Other minerals of the metagabbro include ilmenite that is commonly replaced by sphene, biotite, magnetite, calcite, and sericite.

Both hornblende and relicts of calcic plagioclase that occur as aggregate pseudomorphs of clinozoisite and albite appear to be phenocrysts that are set in the ophitic groundmass in a few of the specimens sectioned. The apparently phenocrystic hornblende strongly suggests that the protolith of the metagabbro was a fine-grained hornblende gabbro. A magmatic origin of the hornblende seems confirmed inasmuch as metamorphic hornblende would reflect an anomalously higher metamorphic grade than that of the metamorphosed sedimentary and volcanic rocks that the metagabbro intrudes.

A phyllitic, sheared, or fractured texture modifies the ophitic texture of the metagabbro at many places. Where the modified texture is present all the minerals except hornblende and part of the clinozoisite are commonly concentrated in tabular or lenticular zones parallel to the schistosity or to minute shears, or in tiny veins in fractures that cross the schistosity. The veins are of particular interest inasmuch as their local mineral content commonly varies in accordance with that of immediately adjoining wallrock.

The ophitic texture is completely obliterated in some places, and hornblende, clinozoisite, and albite, as well as the other minerals, are segregated in separate thin layers. The albite is commonly microporphyroblastic. Such rock is indistinguishable from amphibolites in the region that are of mafic volcanic origin, but its mafic intrusive parentage is inferred from locally crosscutting contact relations, and from its association and compositional affinity with similar rocks in which the ophitic texture is preserved.

Locally the metagabbro is retrogressively metamorphosed to a chlorite-quartz-calcite-albite rock in which the hornblende has been completely altered to chlorite, and the plagioclase has been almost completely altered to a mixture of quartz, calcite, epidote, and sericite. The calcite is commonly rusty weathered and porphyroblastic, and locally it is the principal mineral. The rock might be taken for a limestone were it not for the rather abundant chlorite, quartz, epidote, and actinolite that it contains; its gradation into ophitic rocks; and its lack of bedding. These rocks are of the same low metamorphic 
grade as the metamorphosed sedimentary and volcanic rocks that adjoin them.

The relations between the metagabbro and the ultramafic rocks are clear at a locality 1.7 miles northeast of Lowell village; they are in a rather prominent ledge, where numerous dikes intrude dunite and serpentinite. The dikes, which are 1 inch to 2 feet thick, are altered largely to chlorite and actinolite. An exposure of metagabbro that is in contact with serpentinite is located about 1.6 miles east of the street triangle in North Troy, near the western border of the ultramafic body that crops out within a prominent bend of the Canadian Pacific R.R. This exposure has been described by Richardson (1908, p. 283-284), who concluded that the metagabbro intrudes the serpentinite. The metagabbro at this locality has been altered to tremolite to a depth of several inches next to the contact with the ultramafic rock. The relations here are equivocal, and exposures inadequate. The outcrop pattern suggests that the metagabbro is a tabular inclusion, but the fact that it is finer grained at the margin adjoining the serpentinite suggests that this is a chilled border phase, in support of Richardson's interpretation.

Some of the largest masses of metagabbro known in the Missisquoi Valley and vicinity intrude the Moretown formation south of Route 105, and 1.75 miles east-southeast of North Troy. Others intrude the Stowe formation in Leland Hill about $1 \frac{1}{2}$ miles south-southwest of the village of Lowell. At the latter locality two nearly concordant dikes of mottled metagabbro more than 100 feet thick strike northnortheast across the easternmost two of the three summits of the hill. The average grain size is about $1 \mathrm{~mm}$. This rock (table 4, column 3), which was selected primarily for the degree of preservation of ophitic texture, contains more clinozoisite and sphene, and less hornblende, chlorite, albite, and quartz than is in the average metagabbro of the area of the present study. It seems typical of hornblende gabbro that has been little altered except for saussuritization. Aggregate pseudomorphs of clinozoisite after calcic plagioclase are as much as $3 \mathrm{~mm}$ long; they suggest the size of the probable labradorite grains and explain the mottled appearance of the rock.

A metagabbro sill, the protolith of which was evidently hornblende gabbro, is adjoined by low-grade metamorphic rocks in the transition zone between the Stowe and Moretown formations that is exposed about 0.3 mile south-southeast of Big Falls in the town of Troy. The exposures, which are about 500 feet east of the road along the Missisquoi River, are located along a brook in a rocky pasture. The metagabbro shows varied alteration. Massive mottled hornblende-clinozoisite-sphene rock that shows little evidence of mineral segregation forms much of the sill. Within the western border 
of the sill and next to the massive rock is phyllitic hornblende-quartzsphene-epidote-chlorite rock; the phyllitic rock contains lightcolored tabular and lenticular segregations of epidote that are visible with the naked eye, and microscopic segregations of quartz. Chlorite is segregated with both the epidote and quartz, and also in small pockets by itself. Sphene is concentrated at the edges of segregations and thin layers of sphene diverge within the segregations. The divergence of the layers of sphene suggests spreading apart of the schistosity with growth of the segregations. Quartz-sericitechlorite phyllite in the Stowe formation crops out west of the sill of metagabbro. Greenstone, 5-10 feet thick, is interbedded with the phyllite in the hillside south of the brook and about 50 feet from the metagabbro sill. Both the phyllite and the greenstone are low-grade metamorphic rocks.

A nearly concordant dike of metagabbro, about 10 feet thick, that is altered to chlorite-quartz-epidote-calcite rock cuts sericite-chloritequartz schist of the Stowe formation at the summit of Mount Norris on the boundary between the towns of Lowell and Eden. The discordant contacts with the schist show the magmatic intrusive origin of this rock. Granoblastic texture predominates in the metagabbro and its mineral assemblage is of low metamorphic grade, in agreement with that of the adjoining schist; thus the dike rock has been regionally metamorphosed.

A sill of massive metagabbro, about 200 feet thick, that in places is rather thoroughly carbonatized, crops out on the northeastern slope of Farman Hill in the extreme southeastern corner of the town of Westfield. The least altered portion of the rock is composed chiefly of epidote, bornblende, chlorite, quartz, and sphene. The carbonate rock is made up of calcite, chlorite, quartz, actinolite, and epidote.

Other exposures of the metagabbro that are conveniently accessible are located: (a) 2.4 miles east-northeast of the village of Troy and a little southwest of the point where the highway (Route 100) crosses the Portland-Montreal oil pipeline, (b) 1.8 miles east-northeast of the highway intersection (Routes 100 and 58) in Lowell village and a little northeast of a sharp bend in a side road, and (c) about 1 mile southsoutheast of Bigelow Basin in the northeastern part of the town of Eden, at a point 300 feet northwest of a road.

\section{ELTEY MOUNTAIN GRANTTE}

The Eltey Mountain granite is herein named for exposures on Eltey Mountain at the southeast edge of the map area. It is a medium- to fine-grained biotite granite that forms elliptical to tabular plutons emplaced nearly parallel to the steeply dipping beds of enclosing metamorphosed sedimentary and volcanic rocks, which are generally the Moretown formation and its Coburn Hill volcanic member. The 
granite of the central parts of the plutons is commonly massive; that near the borders is schistose and locally darker colored with a composition nearer to diorite than to granite. Joints in the granite strike north-northeast and dip steeply west, in general parallel both to the schistosity of the granite and to the bedding of the enclosing rocks. The strike of the joints is particularly well shown on Eltey Mountain by the dissection of the summit ridge and by the north-northeast trend of gullies that head on this ridge (pl. 1).

The massive granite is of two varieties; potassic granite is most common, though sodic granite also occurs. The potassic granite has a typical granitic texture and contains abundant anhedral grains of alkalic feldspar (microcline-perthite, microcline, perthite, or orthoclase), and lesser amounts of subhedral albite. The sodic granite has a typical monzonitic texture (Grout, 1932, pp. 42, 84, 85) characterized by a predominance of subhedral grains of albite-sodic oligoclase. The alkalic feldspars are anhedral and are in interstices between the plagioclase grains. Quartz is anhedral and interstitial and is less abundant than feldspar in both the granitic and monzonitic textural types. Biotite is also interstitial. The plagioclase is apparently all less calcic than $\mathrm{An}_{20}$; therefore, the rock is not a quartz monzonite or granodiorite. But it seems likely that some of the rock, in which sodic oligoclase and quartz are the most abundant minerals, closely approaches granodiorite in composition. Locally, rock with a monzonitic texture is dark colored and contains biotite which is exceeded in abundance only by oligoclase; it is probably a diorite.

In general the minerals of the massive granite are, in decreasing order of abundance, microcline-perthite, quartz, albite-oligoclase, biotite, sericite, ilmenite, epidote, magnetite, apatite, and zircon (table 4, column 4). Feldspars locally are replaced by sericite and epidote; and biotite by chlorite, sphene, and magnetite. Cracks between and across grains contain sericite, biotite, and epidote.

The texture of the schistose granite is probably protoclastic. The textures that are commonly referred to as flaser structure and mortar structure are characteristic; they reflect movement and progressive granulation during magmatic crystallization. Two generations of quartz are involved: a first generation remains in the "eyes" of the flaser structure and is identical with quartz of the massive granite except that it is commonly strained; a second generation of unstrained quartz, and muscovite and biotite, seals cracks in the feldspars and forms the "mortar" of the mortar structure. The schistose granite differs mineralogically from the massive granite chiefly in that sericite, which accounts for the schistosity of the rock, is more abundant than biotite. The schistosity is undulatory because the sericite foliae pass 
around the "eyes" of the flaser structure; the average attitude of the schistosity is about parallel to the principal planes of the "eyes."

Fine-grained granite and aplite occur in sills and dikes. The finegrained granite is little different from the granite of the plutons except for smaller grain size. It forms sills and nearly concordant dikes that range in width from a foot to hundreds of feet; the larger ones are extensions of the plutons of the Eltey Mountain granite. Aplite forms dikes that are a fraction of an inch to 10 feet thick and that intrude both the granite and adjacent country rock. The aplite differs from the granite chiefly in that orthoclase and microcline of the aplite predominate over microcline-perthite and plagioclase, and the grains are nearly all anhedral and too small to be distinguished with the naked eye.

The most accessible exposures of typical massive granite are in the northwest slope of Eltey Mountain, about 1 mile south of the highway (Route 58) from Lowell to Irasburg. Here, joints that parallel a very faintly schistose fabric in the granite strike N. $5^{\circ} \mathrm{E}$. and dip $54^{\circ} \mathrm{W}$. Typical schistose granite and related dikes crop out half a mile northnorthwest of Smith Pond in the town of Newport, at a locality about one-fourth mile east of the highway (Route 100) from Troy to Newport. The foliation is quite variable, but the average strike and dip at this locality are N. $36^{\circ} \mathrm{E}$. and $76^{\circ} \mathrm{W}$., respectively. Irregular aplite dikes, a few inches thick, that intrude the granite strike about east and dip vertically. Similar aplite dikes intrude pillow lavas of the Coburn Hill volcanic member of the Moretown formation that are exposed a few hundred feet to the west. The aplite dikes also intrude networks of thin metadiabase dikes that in turn intrude the Coburn Hill volcanic member in the vicinity. A good exposure showing the latter relation is about 0.35 mile east-southeast of the highway intersection (Routes 100 and 105) on the north slope of a hill. A dike of aplite about 6 feet thick cuts the phyllite-slate of the Moretown formation one-fourth mile south-southeast of this intersection and 500 feet east of the highway (Route 100). Diorite forms what is probably a thick sill which crops out half a mile west of Smith Pond and about 800 feet southwest of the highway intersection (Routes 14 and 100).

Hypabyssal granitic rocks that intrude formations older than the Moretown have been discovered at a few places; doubtless others exist but have not been found because of their small size. A sill of finegrained granite, which is 2 feet thick, intrudes the Stowe formation a little northwest of the summit of Black Hill, in the southern part of the town of Newport. A dike of granite, which is 6 feet thick and nearly concordant with the schistosity, cuts the Stowe about 0.4 mile southsoutheast of the road intersection known as South Newport; the contacts of this dike are planar whereas the bedding of adjacent meta- 
sedimentary rock is folded, which indicates emplacement after folding. A small body of diorite crops out 0.9 mile south-southwest of the junction of Jay Branch and the Missisquoi River; it is in the belt of the Ottauquechee formation about 400 feet west of the river. The contacts of the body of diorite are covered, but it is estimated to be about 100 feet long and 50 feet wide. Chlorite formed by alteration of biotite is exceeded in abundance only by albite in this rock.

\section{LAMPROPHYRE}

Unmetamorphosed mafic hypabyssal rocks that are younger than the metagabbro are characteristic of the region, though not common in outcrops because of their small size. Only three dikes were found in the area of the geologic map (pl. 1), but it is very likely that other dikes of such rock exist in this area. They have been discovered in several areas to the south in Vermont (Albee, 1957; Cady, 1956; Osberg, 1952, p. 70-72) and to the north in Quebec (Cooke, 1950, p. 105-110).

The unmetamorphosed mafic rocks are commonly aphanitic, though some are coarse enough that a diabasic texture is recognizable in hand specimens. They are black on the fresh surface, locally porphyritic or amygdaloidal, and weather dark brown. Columnar structure transverse to tabular bodies has been seen locally. In the field these rocks have been described as basalt and diabase.

Thin-section study most commonly reveals a diabasic texture in which randomly oriented laths of plagioclase feldspar with mutual contacts surround smaller interstitial masses of pyroxene and other minerals that crystallized later. The ophitic texture, characterized by the reverse relation in which pyroxene is predominant, is less common. Locally the rock tends to a sugary texture in which all the mineral grains are nearly euhedral and appear to have crystallized at the same time. This texture suggests lamprophyre. Modal variations, particularly larger proportions of hornblende and nepheline, and relatively smaller amounts of pyroxene and plagioclase, indicate that these are lamprophyres, although the textures of rocks with this varied assemblage of minerals are as likely to be subdiabasic or subophitic as sugary. Lamprophyres east of the Green Mountains in Vermont include spessartite and camptonite (Chidester, 1962, p. 85; White and Billings, 1951, p. 662), and the fourchite to be described here.

The fourchite is in a dike that is about 2 feet thick near the west side of the crest of an elongate north-trending hill 1.9 miles southsoutheast of the village of North Troy. The enclosing rock is phyllitic graywacke of the Ottauquechee formation. The dike is concordant with the schistosity. Megascopically it resembles an amygdaloidal basalt. Microscopic examination revealed the following minerals, 
listed in the decreasing order of their abundance: augite, analcite, titanomagnetite, calcite, barkevikite, nepheline, chlorite, biotite, and leucoxene (table 4, column 5). Randomly oriented crystals of augite and barkevikite and phenocrysts of titanomagnetite produce a microporphyritic texture. Nepheline seems to be a primary mineral interstitial to the augite and barkevikite crystals. Round to oval amygdules contain chiefly analcite and calcite; biotite and chlorite are centrally located in some of the amygdules. Barkevikite and nepheline form comb structures at the margins of some of the amygdules. Analcite, calcite, biotite, nepheline, barkevikite, and possibly glass also form vague interstitial accumulations that are neither part of the ophitic fabric nor within the amygdules. Skeleton crystals of titanomagnetite are filled with calcite and chlorite. It appears, therefore, that all the minerals except augite and magnetite are of deuteric as well as of strictly magmatic origin. Some of the analcite and calcite in the amygdules was possibly formed later than deuteric alteration.

Two postmetamorphic mafic dikes intrude the Hazens Notch formation southeast of Route 105-A, about 0.15 mile southwest of the point where this highway crosses the summit ridge of the Green Mountains, in the northern part of the town of Jay. The two dikes, which are exposed in a road cut, strike north-northwest and dip steeply east transecting bedding foliation. The larger dike is as much as 6 feet thick and the smaller of the two less than a foot thick.

\section{METAMORPHISM}

Metamorphic zoning is shown by the pattern of the hornblende isograd (pl. 1), which separates rocks of the epidote amphibolite facies, in and near the Green Mountains and near Coburn Hill and Eltey Mountain, from rocks of the greenschist facies in the Missisquoi Valley and in areas to the southeast and south. Various metamorphosed mafic volcanic and hypabyssal rocks furnish the evidence for varied metamorphic intensity. These include amphibolites in the Hazens Notch and Jay Peak formations, amphibolite and greenstone in the Belvidere Mountain amphibolite and in the Coburn Hill volcanic member of the Moretown formation, greenstone in the Stowe formation, and both progressive and retrogressive facies of the metagabbro. Garnet and biotite rarely occur in the argillaceous schists; therefore, if one were to use these minerals as an index of the degree of metamorphism, he might be led to rank most of the schists in the chlorite zone, despite the presence of effects of lower middlegrade metamorphism (epidote amphibolite facies) among the mafic volcanic rocks. The absence of biotite in the argillaceous schists of appropriate metamorphic grade is due to the chemical composition of 
the rocks. ${ }^{7}$ The absence of garnet, on the other hand, generally indicates that the garnet zone has not been attained. Locally, as near Belvidere Mountain, the metamorphism may have reached the intensity of the garnet zone, but the rocks were of such composition that garnet was not formed, or such garnet as may have formed has been completely destroyed by retrograde alteration.

A short distance southwest of Belvidere Mountain, rocks of the Hazens Notch formation contain small euhedral porphyroblasts of garnet within larger albite porphyroblasts. This texture was interpreted as a relict feature, in which all garnets not protected by albite were altered to chlorite. This implies that the garnet zone was originally more widespread near the axis of the Green Mountain anticlinorium and that retrograde alteration has destroyed nearly all evidence of its existence.

Metasomatism played a small, though significant, role in regional metamorphism. It includes formation of porphyroblasts and quartz segregations, and, on a larger scale, steatitization. Most of the metasomatic effects are the result of metamorphic differentiation, which is characterized by the movement of material (except water) only a few inches (as in the formation of porphyroblasts and quartz segregations) or a few feet (as in the formation of steatite and chlorite rock). In contrast, carbon dioxide metasomatism, which produced the talc-carbonate rock, resulted from the movement of material through long distances.

Contact metamorphism is shown principally by the development of the epidote amphibolite facies in the Coburn Hill volcanic member of the Moretown formation in the vicinity of the pluton of the Eltey Mountain granite at Coburn Hill and in metagabbro near the granite pluton at Eltey Mountain. It is probably also shown by the formation of calc-silicate rock at the contacts of ultramafic plutons, principally as observed in the vicinity of the Lowell Quarry in the eastern slope of Belvidere Mountain.

The source of heat responsible for metamorphism is not clear except in the contact metamorphic aureoles mentioned above. Intrusive igneous rocks other than the ultramafic plutons, the contact metamorphic effects of which are very local, have not been discovered in the Green Mountains where the largest area of middle-grade metamorphic rocks is located. The coincidence of this area of middle-grade metamorphism with the axial region of the Green Mountain anticlinorium, however, suggests the possibility that the

\footnotetext{
${ }^{7}$ Albee (1952) has calculated, from data obtained from numerous chemical analyses of argillaceous-arenaceous sedimentary rocks, what minerals would be present if such rocks were metamorphosed. It was found that the range of chemical composition is such that many argillaceous rocks would not acquire biotite until metamorphism had reached the intensity of the garnet, kyanite, or even the sillimanite zone.
} 
metamorphic high is due in part simply to differential uplift of rocks that were once more deeply buried than those to the east and west.

\section{STRUCTURE}

\section{MAJOR STRUCTURAL FEATURES}

The Green Mountain anticlinorium and subsidiary anticlines and synclines are the major longitudinal structural features of the area. The axial planes of these folds diverge upwards; thus those in western areas dip steeply east and those in the eastern areas dip steeply west. The axial anticline of the Green Mountain anticlinorium, in which the oldest rocks are exposed, trends north-northeast and is a little west of the crest of the Green Mountains northwest of Jay Peak (pl. 1). The Hazens Notch formation crops out in this belt. The Jay Peak syncline, whose axial plane dips steeply southeast, plunges southwest in the vicinity of Jay Peak. The Jay Peak formation overlies the Hazens Notch formation in this vicinity and is itself succeeded in the trough of the syncline by the Ottauquechee formation. The principal syncline of the area is the Missisquoi Valley syncline, which is centered 1-2 miles east of the Missisquoi River in the long belt of the Moretown formation. To the southeast of the Missisquoi Valley syncline is the Lowell Mountain anticline. The axis of this anticline may be traced along the belt of the Stowe formation that is centered a little west of the crest of the Lowell Mountains. The axes of the Missisquoi Valley syncline and the Lowell Mountain anticline plunge gently north and their axial planes dip steeply west. In the extreme southern part of the Lowell Mountains, the Lowell Mountain anticline plunges southwest. A rather pronounced depression in the longitudinal fold system is marked by the northwesterly bulge of the Stowe formation in the vicinity of Hadley Mountain on the Eden-Lowell boundary.

The structure is most complex in the vicinity of Belvidere Mountain and Tillotson Peak, between the Jay Peak syncline and the Missisquoi Valley syncline, where the north-trending Gilmore anticline and smaller but still considerable northwest-trending folds combine to form a complicated pattern. Most conspicuous of these transverse folds is the syncline that contains the Belvidere Mountain amphibolite at Tillotson Peak in the western part of the town of Lowell (pl. 1, inset). As discussed in the section on the Belvidere Mountain amphibolite, the plunge of the nose at the west end of this syncline is westward, and therefore overturned, according to an interpretation that is based upon the correlation of this amphibolite and the Belvidere Mountain amphibolite. Other prominent transverse synclines are near Belvidere Mountain in Lowell and Eden. One of these, which contains the Belvidere Mountain amphibolite, plunges southeast at 
the southwest border of the Lowell Quarry; another, which contains both the amphibolite and the overlying Ottauquechee formation, plunges southeast along Hutchins Brook, and carries the amphibolite northward along the west side of Schofield Ledges in a narrow belt that is interpreted as a subsidiary syncline; a third, in which Belvidere Mountain amphibolite forms the core of a doubly plunging syncline, is located near Tillotson Mill.

South of the latitude of Eden Mills, the map pattern is relatively simple, and the projection of the Gilmore anticline is a rather simple, gently south-plunging subsidiary fold of the Green Mountain anticlinorium.

Additional transverse folds, comparable in size to these, probably occur at least as far north as Hazens Notch. They are suggested by the pattern (pl. 1) of contacts between amphibolite and gneiss in the Hazens Notch formation. The relations of this gneiss and amphibolite are similar to those of the Belvidere Mountain amphibolite and underlying gneiss on Belvidere Mountain. The west-northwest strike of the nearly vertical strata of the Hazens Notch formation, particularly noticeable in the cliff that forms the north wall of Hazens Notch, also suggests that there are other transverse anticlines and synclines. Ultramafic plutons emplaced in the Hazens Notch formation trend west-northwest in general concordance with adjacent bedding in the area. Westward from Hazens Notch the strikes of bedding, axial plane foliation, and contacts between gneiss and amphibolite swing from westerly to northerly and parallel the contact between the Hazens Notch formation and the overlying Jay Peak formation in the upper eastern slope of Burnt Mountain. A similar swing to the northeast occurs east of Hazens Notch. Thus the transverse folds merge with the pattern of the longitudinal folds on both flanks of the Gilmore anticline.

The relation of transverse folds to the major longitudinal structures is much less clear north of Hazens Notch, where lithologic contrasts such as that between gneiss and amphibolite are uncommon and the bedrock in the valley of Jay Brook is widely covered by surficial deposits. The eastward strikes swing to the northeast, where the Gilmore anticline blends with the general structure of the Green Mountain anticlinorium north of the latitude of Gilpin Mountain in northwestern Westfield.

\section{MINOR STRUCTURAL FEATURES}

Minor structural features include: (a) primary structures such as the bedding of the metamorphosed sedimentary and volcanic rocks and possibly the layering of the ultramafic intrusive rocks; and (b) secondary features that have been superimposed upon the primary structural features, such as folds, slip cleavage, fracture cleavage, 
fold layers, joints, faults, shear zones, and shear polyhedrons (the last four are particularly characteristic of the ultramafic intrusive rocks). Slaty cleavage, schistosity, and gneissosity are foliations developed parallel to the various primary or secondary planar features; they may be intersected by later generations of secondary features. Their expression is closely related to metamorphic intensity, structural position, and lithology. The intersections of the various planar features with each other, chiefly that of slip cleavage or transverse foliation-which is developed on slip cleavage - with bedding or bedding foliation, commonly produce lineations that are recognizable on slip-cleavage, bedding, or foliation surfaces. Fold and crinkle axes are common linear features. Rods of quartzite are formed that parallel the fold axes where the crests of folds in thin quartzite beds are separated, or where portions of the limbs of folds are segmented by slip cleavage. Elongated lenses of coarsely granular white quartz, segregated during metamorphic differentiation, are similarly located and oriented. Other linear features parallel to fold axes include alinement of mineral grains and streaks on foliation surfaces.

\section{BEDDING AND BEDDING FOLIATION}

Individual beds of conglomerate, quartzite, and limestone, which are commonly marked by differences in color, texture, and mineralogy, can be traced as much as 100 feet. Where parallel to foliation, or layers in schist, gneiss, granulite, greenstone, or amphibolite, these beds suggest that the foliation and layers reflect bedding. Bedding foliation is very common, especially in the Hazens Notch and Moretown formations; it is a secondary foliation developed parallel to bedding, or to compositional layering that is parallel to bedding but produced by segregation of minerals during metamorphic differentiation. In areas of intense folding, the trends of dip and strike of folded bedding or bedding foliation are tangent to the crests of a series of folds. The local attitudes of bedding and bedding foliation diverge rather widely from average trends; consequently, though they are parallel in detail to the boundaries of larger units, they may not show this relation at the scale of the map (pl. 1). Bedding foliation is much more common than the symbols on the map would indicate; even the foliation that does not show a clear relation to bedding in outcrop probably includes more bedding foliation than other types. The relative abundance of such obscure bedding foliation is particularly clear in large exposures where the foliation is parallel to quartzite beds that are separated by much more than the width of the average outcrop. The cliff on the north side of Hazens Notch shows foliation that is parallel to widely separated beds of quartzite. 


\section{LAYERING IN ULTRAMAFIC ROCKS}

In the ultramafic rocks, layers one-fourth inch to several feet thick are common; these reflect differential serpentinization of dunite. The layering is best seen on the weathered surface, where the serpentinite is light gray green in contrast to the buff to reddish brown of the dunite. Magnetite that formed during serpentinization occurs as dimensionally parallel elongate aggregates, as continuous irregular layers, and as pseudomorphs after pyroxene, which contribute to the effect of layering. The differential serpentinization seems to have been controlled by a primary layering that generally is only poorly shown by aggregation of primary chromite and magnetite, of relict pyroxene, and of magnetite aggregates pseudomorphic after pyroxene. In a few places, notably at Browns Ledges in Lowell and Westfield townships, primary layering is distinguished by marked differences in pyroxene content of different layers.

The attitude of the layering varies within an ultramafic pluton, particularly at or near faults and shear zones. The relation of the layering to the contacts of the plutons is uncertain, inasmuch as broad shear zones of schistose serpentinite in which the layering has been completely obliterated adjoin the contacts. It is tentatively concluded that the differential serpentinization occurred early in the deformation, because recognizable secondary structures, including joints, faults, and shear zones, cut the layers.

\section{FOLDS AND CRINKLES}

Minor folds range in amplitude from a fraction of an inch to hundreds of feet, though the amplitudes of most are less than a foot. The larger open folds are in massive, granular rocks. Schist and phyllite contain small, tight folds and irregular crinkles in the schistosity. Folds, in the rare quartzose beds that occur in schist, are commonly preserved only as fold crests or as S-shaped remnants of folds whose limbs have been greatly thinned. The schistosity of serpentinite is locally folded near the contacts of ultramafic plutons.

Most of the minor folds have long and short limbs that indicate the relative movement at the point of observation; the usefulness of this feature as an indicator of the position of the minor folds on larger folds varies within the area. The patterns of folds with limbs of unequal length are referred to as dextral where they are offset to the right in plan and sinistral where they are offset to the left; folds with limbs of equal length are referred to as neutral. The patterns of minor folds and the trend of bedding are shown by symbols on the geologic map (pl. 1).

Two principal systems of minor folds are recognized (fig. 3). Longitudinal folds, which are the most commonly observed, trend northnortheast and are rather consistent with the pattern of the Green 


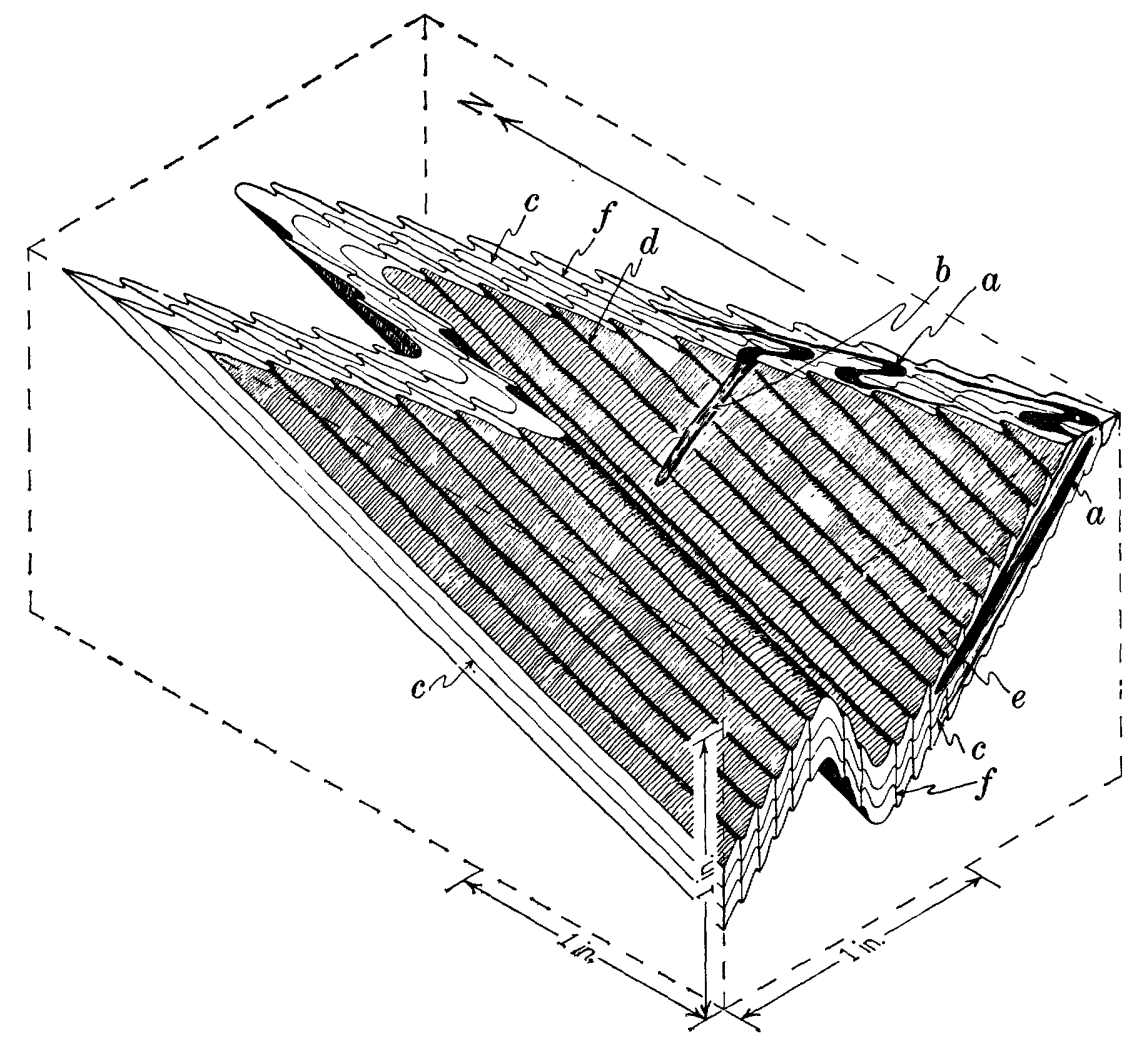

Fraure 3.-Large-scale diagram illustrating the relation between minor cross folds and minor folds of the longitudinal fold system, and other minor structural features: $a$, small east-trending isoclinal cross folds shown chiefly by lenses of quartzite (solid black); $b$, rodding of quartzite; $c$, bedding schistosity (distance between planes of schistosity somewhat exaggerated); $d$, crinkles parallel to north-trending longitudinal folds; $e$, fine striations and tiny crinkles; $f$, slip cleavage.

Mountain anticlinorium. They are commonly harmonic flexural folds closely associated with other folds of the same system. Slip and fracture cleavage are subparallel to the axial planes of the longitudinal folds and are refracted by competent beds. Crinkles are common. The longitudinal folds show a rather uniform movement sense within local areas that is consistent with their being interpreted as drag folds on the limbs of the major longitudinal anticlines; for this reason, they are useful in determining tops of beds. The minor folds in the east limb of the Lowell Mountain anticline, which have patterns opposite to those of normal drag folds, are a notable exception.

Cross folds trend west-northwest roughly parallel to the trend of the larger transverse folds, such as the syncline in the vicinity of Tillotson Peak. The cross folds are less commonly harmonic folds and are generally isolated from other folds of the same system; they show no consistent movement sense. Transverse schistosity is common. The 
relations of the cross folds are best shown by thin quartzite interbeds in the schist of the Hazens Notch formation. The quartzite beds are very tightly folded about axes that plunge east on the east flanks of the major anticlines of the Green Mountain anticlinorium, west in their west flanks, and are transverse and horizontal at the anticlinal crests. The long limbs of the folds in the quartzite beds, and more rarely some of the short limbs are very nearly parallel to their axial planes and to the foliation of the surrounding schist. This foliation and the axial planes of the cross folds are in turn folded about the north-trending axes of the minor folds of the longitudinal Green Mountain fold system. The minor cross folds that have been found bent in minor longitudinal flexures are commonly preserved only as isolated fold crests from which the limbs have been separated. Under more extreme conditions of deformation the crests are not preserved and all that remains is a rodding that may be positively identified as a feature of the cross folds only where it is found to be parallel to the axes of nearby crests of cross folds.

\section{SLIP CLEAVAGE AND TRANSVERSE SCHISTOSITY; FRACTURE CLEAVAGE; FOLD LAYERS}

Slip cleavage, a spaced cleavage that transects a preexisting schistosity and is associated with small crinkles is the most common planar feature transverse to bedding in this area and is particularly well shown in the Ottauquechee formation. Slip cleavage is wavy, discontinuous, and irregularly spaced from a fraction of a millimeter to a few millimeters apart; it is best developed in micaceous rocks. In more granular rocks, in which platy minerals happen to be absent, the cleavage is simply a fracture cleavage. Fold layers (fig. 4) are thin transverse layers of sigmoid folds that are commonly an inch or less thick and in some places several feet apart. They substitute for slip and fracture cleavage in granular rocks that contain paper-thin zones of bedding foliation a fraction of an inch apart, and they are locally transitional into slip and fracture cleavage. The granulite of the Moretown formation shows these relations. Slip cleavage grades into a transverse foliation - commonly schistosity-with the development of platy minerals in and parallel to the slip-cleavage surfaces; it commonly obliterates earlier formed foliation, generally bedding foliation. Slip cleavage and transverse schistosity are about parallel to the axial planes of the small folds and crinkles, and subparallel to the long limbs of tight folds.

Slip cleavage and related foliation have been identified in association with both the early cross-fold and the later longitudinal-fold systems, but slip cleavage that approaches parallelism to the axial planes of the longitudinal folds is by far the most common and most. readily recognized. Transverse schistosity is most commonly par- 


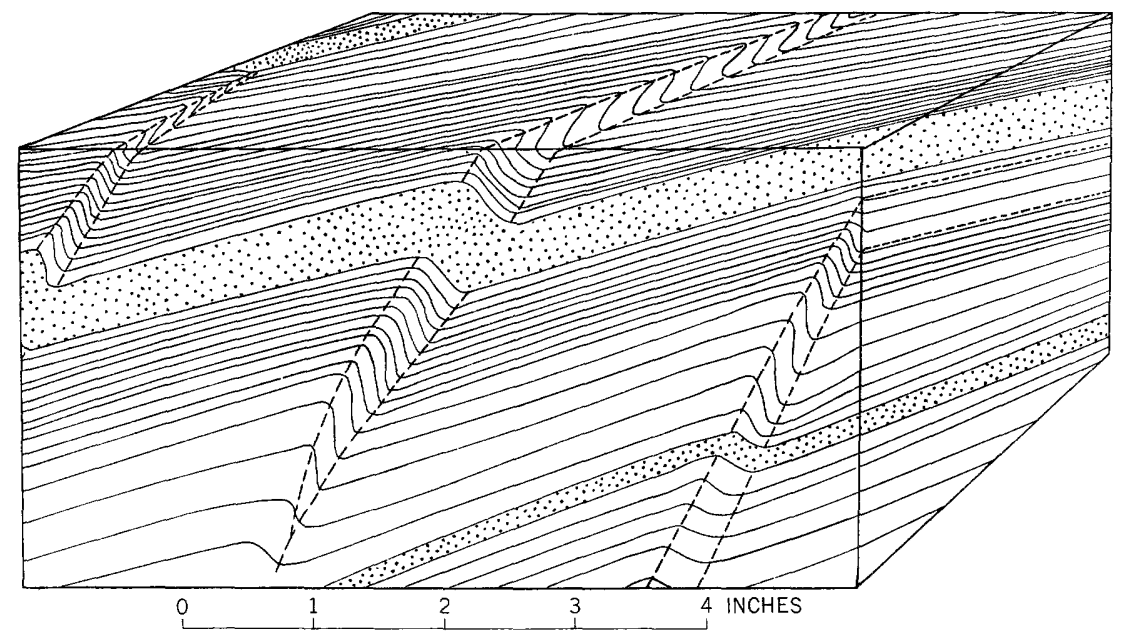

FIGURe 4.-Block diagram illustrating fold layers in interbedded granulite and quartzite of the Moretown formation.

allel to the axial planes of the minor cross folds. Transverse schistosity is less common than bedding foliation.

\section{OTHER MINOR STRUCTURES}

Several other details of structure are significant. Most of these are in the plutons of igneous rock and in some places are too small to show at the scale of the map (pl. 1).

Joints are common. In the plutons of the Eltey Mountain granite, which are in the east limb of the Lowell Mountain anticline, a set of joints strikes north-northeast and dips steeply west in general parallelism with foliation of the granite, with bedding of enclosing metamorphosed sedimentary and volcanic rocks, and with the axial plane of the anticline. Rectangular systems of cross joints characterize the dunite of the ultramafic plutons.

Faults appear to be confined chiefly to the ultramafic plutons and their immediate vicinity. The largest is a small thrust fault where dunite has moved northeastward over the amphibolite in the syncline bordering the southwest side of the Lowell Quarry. Total movement is unknown but is probably not more than 200 feet. The wall of the pluton at the Lowell Quarry is also offset by numerous nearly vertical faults that reflect the contrast in competency between the relatively weak serpentinite and the schist and amphibolite. Narrow shear zones are formed along the faults; wider ones include large masses, which consist chiefly of schistose serpentinite and are commonly arranged near and parallel to the contacts of the pluton. A small fault appears to terminate the Umbrella Hill formation in the southeastern part of the town of Newport. 
Shear polyhedrons (see Chidester and others, 1951, p. 7-8; Chidester, 1962, p. 24, 71), which are irregular polyhedral units of massive, essentially unsheared serpentinite separated by thin zones of sheared serpentinite, characterize ultramafic plutons that are extensively serpentinized. The shear polyhedrons are probably a feature of solidstate intrusion.

\section{STRUCTURAL SYNTHESIS}

The various major and minor structural features are closely related geometrically, and probably by mode of origin, to each other, to stratigraphic position, and to the lithologic features of the rock. The genetic relations of features seen in outcrop, such as slip cleavage, transverse schistosity, fold layers, and minor folds, can generally be determined satisfactorily. The genetic relationship of these features to larger structural features, and of differently oriented larger structural features to each other, are, however, more difficult to determine and commonly appear to be ambiguous, so that more than one interpretation is possible.

The origin and relations of bedding and bedding foliation in the metamorphosed sedimentary and volcanic rocks, of layering, joints, faults, and shear polyhedrons in the ultramafic rocks, and of joints in granite are particularly significant in consideration of the origin of those rocks. They have already been discussed, and will not be further considered here.

The close genetic relation of the major and minor folds, particularly of the longitudinal fold system, is shown by their generally consistent orientation and movement sense. General parallelism between the traces of the axial planes of minor cross folds and those of the large transverse folds suggests a genetic relation which is less certain, however, than in the longitudinal folds, chiefly because the plunge and movement sense of the minor cross folds are erratic.

Cleavage and transverse foliation are closely related to the folds. In the axial regions of major longitudinal folds, the subparallelism between slip cleavage and the axial planes of minor longitudinal folds indicates that the slip cleavage was formed during the development of the longitudinal fold system. In the same regions, transverse schistosity that is parallel to the axial planes of the cross folds, and commonly parallel to the bedding foliation except in the noses of the cross folds, appears to have been formed with the cross folds. In the steep limbs of major longitudinal folds, away from the axial regions, the slip cleavage and transverse schistosity can be less certainly related to the two fold systems. Probably most of the slip cleavage in the limbs of the major folds was formed during development of the longitudinal fold system, but in a few places, particularly where the slip cleavage is related to steeply plunging folds, it may be genetically related to the cross folds. 
In contrast, most of the transverse schistosity in the limbs of the major folds is, like that of the axial regions, probably related to the cross folds, though some grades into slip cleavage formed with the longitudinal folds.

Minor cross folding must have preceded minor longitudial folding inasmuch as the axial planes of all minor cross folds are folded about the north-trending axes of minor longitudinal folds. It should be noted however that the longitudinal folding may not be of the same age at every place and that longitudinal folds possibly formed at one place before minor cross folds formed at another.

The foregoing observations suggest that the large transverse folds that cross the Gilmore anticline also were formed before the major longitudinal folds. Such inferences concerning mutual relationships of the major folds, deduced from interrelationship of the two systems of minor folds, are useful, although supporting data are somewhat obscure (Albee, 1957; Chidester, 1953, 1962, p. 17-22). Here uncertainty arises from not-too-clear genetic relations between the minor cross folds and larger transverse folds (see p. 63). Some of the better exposed large transverse folds, especially the synclines at Tillotson Peak and between the ultramafic bodies at the Lowell Quarry and on Belvidere Mountain, plunge very steeply and appear to be of the type-produced by plastic flow-which antedates flexural folds. The swing of the large transverse folds into parallelism with the trend of the longitudinal structural features at either flank of the Gilmore anticline suggests, but does not require, that the two were formed at the same time.

Culminations and depressions in the longitudinal fold system, such as the depression marked by the northwest salient of the Stowe formation in the vicinity of Hadley Mountain on the Eden-Lowell township boundary, are of the same age and origin as the longitudinal folds (see also Chidester, 1953). It seems significant that the depression at Hadley Mountain is adjacent to the greatest development of transverse folds in the core of the Gilmore anticline. Moreover, the transverse folds are arranged symmetrically with respect to this depression; for instance, the syncline in the vicinity of Hutchins Brook south of Belvidere Mountain swings southeast on the southwest flank of the depression, and that at Tillotson Peak swings northeast on the northwest flank.

The geometric pattern of the complex area of the Gilmore anticline suggests, at first glance, that it is bounded at either border by structural or stratigraphic discontinuities. The confinement of the large transverse folds to rocks below the Stowe formation suggests the existence of an unconformity, or possibly a fault, on the east flank. Also, the somewhat abrupt change in bedding trends, from about west to north-northeastward along the west flank of the anticline, suggests 
that a fault may be present there. Extensive areas which at critical places are covered by surficial deposits, or in which exposures are only intermittent, lead to some uncertainty; but the rocks in the anticlinal tract appear to be conformable with, and gradationally transitional into, the overlying rocks. Faults of significant size and unconformities appear to be ruled out. It has not been feasible to work out a detailed stratigraphic pattern within the tract of the Gilmore anticline; however, it is believed that cross folds are entirely responsible for the complexities and seeming anomalies in bedding trends and other detailed structural features.

Development of a satisfactory genetic theory to explain the structural relations of the area of the present investigation, particularly those within the tract of the Gilmore anticline, encounters several difficulties. Most serious is that posed by the two sets of major and minor folds, whose geometric relations would appear to imply two successive compressional stresses about at right angles to each other. Such a picture of tectonic events would satisfy the geometric relations, but it is not consistent with the general concept of folding in the Appalachian region-namely, that the folds parallel a northeasttrending geosynclinal belt that contains them. Not the least of the difficulties is the awkwardness of explaining the diverse orientation of the principal stresses that are required by the tectonic pattern; the development of such tectonic patterns is difficult to visualize. A possible recourse is to insert faults or unconformities between the two conflicting sets of folds, thereby placing them in different tectonic units. This does not appear to be possible here, as pointed out in the preceding paragraph.

It is beyond the scope of this report to provide detailed data and interpretations bearing on the origin of the transverse structures. However, several recent descriptions and analyses of similar features (Brace, 1958; King and Rast, 1956), and of the behavior of rocks in various structural environments (Carey, 1954), suggest a possible general explanation.

The ultimate cause of all the deformation was probably regional compressional stress produced by shortening of the cross section of the northeast-trending geosyncline. The longitudinal folds seem obviously a direct result of such stress, but the transverse structures are a less obvious result. The latter were probably caused by diversion of rock movement around irregularities in the geosyncline.

The depression in the longitudinal fold system in the vicinity of Hadley Mountain probably reflects a similar depression in the top of the basement rocks upon which the geosyncline formed. This configuration of the basement rocks may be a relict of a similar, though much less pronounced, configuration of the geosyncline, which may have 
taken form before deposition of any sediments. It seems likely that basement features beneath the Gilmore anticline are similarly relicts of the initial configuration of the geosyncline. The presence of the Hadley Mountain depression immediately southeast of the Belvidere Mountain-Tillotson Peak area suggests that in this area the basement feature is a saddle, whose lowest part trends west-northwest at right angles to the longitudinal fold system. Therefore, the picture, possibly before deposition of the bedded rocks, is one of a low submarine ridge that trended north-northeast and was notched by a saddle. Before folding took place the ridge and saddle were completely covered by bedded rocks.

The manner in which the folds were formed is most simply visualized by means of a model that consists of basement rock whose surface configuration contains a north-south-trending ridge notched by a saddle, and overlying bedded rocks that are plastic in the lower part and more brittle in the upper part. The plastic rocks deform by flowage, the more brittle rocks by flexural folding. Under the influence of compressional stress about normal to the ridge, the bedded rocks move in from the sides against the ridge, and longitudinal folds begin to develop on the flanks of the ridge. At the same time, plastic rock moves into the notch of the saddle from both sides and, meeting at the center of the notch, rises and moves north and south against the sides and in this way forms transverse folds. Also, minor cross folds form in other axial areas of the ridge because of the influence of local irregularities in the basement, like those of the saddle but much smaller. The rocks involved in the transverse structures are all low in the section, where they are not only subject to control by basement irregularities but are under enough confining pressure to deform by flowage folding. As deformation continues, longitudinal folding quickly progresses into the axial belt of the buried ridge, and the saddle fills with transverse folds. The transverse folds, which continue around onto the flanks of the Gilmore anticline and are apparently continuous with the longitudinal folds, formed at the same time as the neighboring longitudinal folds.

After the transverse folds were established in the lower part of the section, flexural folding, which had prevailed since beginning of deformation in the upper part of the section, began to extend into the lower rocks, which in the meantime had increased in strength because of folding and metamorphism. This change in the style of folding in the lower rocks marked the end of formation of the transverse structures and is shown especially by the familiar folding of minor cross folds in the minor longitudinal folds.

The failure of transverse folds to appear at stratigraphic levels above the Ottauquechee formation on the east flank of the Gilmore anticline 
suggests that longitudinal folding was the only folding in the upper rocks, which are now exposed in the flanks of major anticlines but are eroded from the axial belts of the anticlines. The larger transverse folds need further investigation to determine the extent to which they are penetrated by minor longitudinal folds. It is possible that the larger transverse folds were consolidated enough during flowage folding to prevent formation of the minor flexural folds of the longitudinal system.

In closing this structural synthesis something should be said of the apparently erratic orientation of minor folds of the Green Mountain anticlinorium, which in many places plunge more steeply than do the major folds. This inconsistency can probably be ascribed to continued deformation after some controlling structural features had become established (Weiss, 1958, p. 34). For example, folds that plunge more steeply than the major folds may form on the flanks of a developing structural salient, in beds that already dip steeply, in response to differential movements principally in the direction of strike. Many of the minor structural features, such as drag-fold and cleavage-bedding relations, fail to reflect the attitudes of major folds because of such inconsistencies. The inhomogeneous orientation of the minor folds of the Ottauquechee formation is most noticeable.

\section{ASBESTOS DEPOSITS HISTORY AND DEVELOPMENT}

Commercial asbestos has been mined during the past 75 years from four quarries on the eastern and southeastern slopes of Belvidere Mountain, in the towns of Lowell and Eden (pl. 1). About 80 percent of the asbestos produced in the United States has come from these quarries. The early production was from the so-called Gallagher pit, which was located at the present site of the southeast end of the Lowell Quarry. In the 1930's the Eden Quarry was opened on the southeast shoulder of Belvidere Mountain, and mining from that quarry continued until early in World War II when the Lowell Quarry was opened northwest of the old Gallagher pit. Since that time the Lowell Quarry has been extended eastward and to lower levels, and the Gallagher pit has been completely obliterated. A new quarry was opened in 1953, in the so-called C-area, which is about one-fourth mile south of the Lowell Quarry.

The present operators (1962), the Vermont Asbestos Mines Division of the Ruberoid Company, constructed a new mill a little east of the Lowell Quarry after World War II. About 85 percent of the asbestos fiber produced in the United States in 1961 was shipped from this mill. Prior to construction of the new mill, an old mill at the Eden Quarry had processed ore transported from the Lowell Quarry by aerial tramway. 
The principal exploration for asbestos in the upper Missisquoi Valley and vicinity was done by the Vermont Asbestos Mines, partly under contract with the Defense Minerals Exploration Administration, during the period 1951-53. Diamond drilling, preceded by geophysical exploration, was undertaken in a wide area on the southeast slope of Belvidere Mountain between the Eden and Lowell Quarries, and in a small area north of Corez Pond and not far south of the east end of the Lowell Quarry. Similar investigations were also made under the drilling contract in several other areas northeast of the Belvidere Mountain area in the towns of Lowell, Westfield, and Troy. These areas were: (a) northeast of Leland Hill, a little southwest of the village of Lowell; (b) 1 mile east-northeast of Lowell village; (c) southern and northeastern slopes of Browns Ledges in the towns of Lowell and Westfield; (d) a strip along the Missisquoi River, chiefly in the town of Westfield; and (e) an area on East Hill in the town of Troy. Vermont Asbestos Mines and the Philip Cary Manufacturing Co. jointly drilled an area 1.5 miles northeast of the village of Lowell, independently of the contract with the Defense Minerals Exploration Administration.

Prospect pits have in the past been opened for asbestos at several localities; the following pits are known to the authors:

Four-tenths mile N. $13^{\circ} \mathrm{W}$. of $Y$-intersection in the street, at the center of the village of Lowell; a short inclined adit full of water, opens southwestward.

1.8 miles $\mathrm{N} .57^{\circ} \mathrm{E}$. of $\mathrm{Y}$-intersection in the street, at the center of the village of Lowell; two prospect pits, one east and the other west of a ledge.

0.13 mile S. $22^{\circ} \mathrm{E}$. of eastern knob of Browns Ledges, near the Lowell-Westfield town line; pit.

1.6 miles $\mathrm{S} .45^{\circ} \mathrm{E}$. of the highway intersection, in the village of Westfield; opening in west side of ledge.

1.2 miles N. $20^{\circ} \mathrm{E}$. of Jay village; blast holes in ledge.

\section{GEOLOGIC RELATIONSHIPS}

The description of ultramafic rocks in a previous section of this report gives the geologic setting of the asbestos deposits in general. In the following discussion a detailed study of the geology and asbestos deposits of the Belvidere Mountain area is briefly summarized and extrapolated to the ultramafic rocks northeast of the Belvidere Mountain area, where critical outer zones are commonly covered by surficial deposits. This discussion is focused chiefly on suggestions for finding new ore that are based on geologic inferences.

Two general types of asbestos ore have been mined in the Belvidere Mountain area-ore that contains rather finely dispersed fibers, and ore in which fibers occur in slip- and cross-fiber veins in otherwise more or less barren rock. 


\section{DISPERSED FIBER}

The principal source rock of commercial asbestos at the present time (1962) is schistose serpentinite, which is the chief ore mined at the Lowell Quarry. The body of ultramafic igneous rock that contains the schistose serpentinite at the Lowell Quarry is in the nearly vertical northeast limb of a tight syncline. The folding and related squeezing of the syncline is considered to be responsible for the schistosity in the serpentinite. Schistose serpentinite is more common near the borders of the ultramafic rock at the Lowell Quarry than in central zones. Chrysotile fibers, which constitute the asbestos, are dispersed through the schistose serpentinite on irregular slip planes that are commonly spaced a fraction of an inch apart. These slip planes are not readily distinguishable with the naked eye and are therefore not as impressive as sharply defined veins, particularly of cross fiber, that occur in dunite and massive serpentinite. The early discovery of cross-fiber asbestos at the old Gallagher pit reflects this situation. The Gallagher pit was opened in ledges of dunite and massive serpentinite that contained well-exposed cross-fiber veins. The deposits of dispersed asbestos fiber in the more easily weathered and eroded-and therefore less favorably exposed-schistose serpentinite northwest of the Gallagher pit were not recognized until the Lowell Quarry was extended into them.

Schistose serpentinite is commonly located along the borders of the ultramafic igneous bodies. It is generally covered by surficial deposits as it was at the Lowell Quarry before stripping operations began. This suggests that more of the dispersed fiber may be found beneath surficial overburden in other parts of the upper Missisquoi Valley and vicinity. Extensive covered areas of this sort that are in need of exploration include the bottom lands along the Missisquoi River in the southeastern part of the town of Westfield; nearly the whole contact of the ultramafic igneous body at Browns Ledges in northern Lowell and southern Westfield townships; parts of the East Hill body in Troy township; and parts of the two ultramafic masses west of Lowell village. Diamond-drilling sites have in the past been selected and holes oriented to pass through the outer zones of the ultramafic rocks if possible, in order to intersect the schistose serpentinite. Sites near outcrops have been chosen to allow for more positive geologic control and to save excessive drilling through overburden. Many holes drilled near the borders of outcrops of ultramafic rock have, however, been too far within the margins of ultramafic igneous bodies, as located by dip-needle and ground magnetometer surveys, to intersect the most promising rock. Future exploration of covered areas by drilling may lead to the discovery of additional commercial ore bodies. 


\section{SLIP- AND CROSS-FTBER VEINS}

Veins of slip- and cross-fiber asbestos in dunite and massive serpentinite were the first to attract attention and are the types of occurrence that have been subsequently explored and exposed in prospect pits. Dunite and massive serpentinite are more resistant to weathering and erosion, so less likely to be covered with surficial deposits than the schistose serpentinite containing the dispersed fiber.

The Eden Quarry, and the quarry in the C-area, about one-fourth mile south of the Lowell Quarry, have yielded more ore of the slipand cross-fiber type than of the dispersed type. Dunite and massive serpentinite are more common in these quarries than in the Lowell Quarry, probably because the enclosing formations are not as steeply dipping and the ultramafic rocks therefore are less affected by folding than those in the Lowell Quarry.

More of the massive than of the schistose type of ultramafic rock has been encountered in drill holes in the belt northeast of Belvidere Mountain, in the towns of Lowell, Westfield, and Troy; hence fiber veins, particularly veins of slip fiber, are a more prominent feature of the diamond drill cores than dispersed asbestos. The most promising samples from diamond-drill holes, ${ }^{8}$ although all of less than ore grade, are from holes east and northeast of Leland Hill, in the town of Lowell; near the east foot of Browns Ledges, in the towns of Lowell and Westfield; and on East Hill, in the town of Troy. The cores from nearly all holes drilled contained traces at least of slip fiber.

\section{OTHER MINERAL RESOURCES}

\section{TALC}

Talc is a significant mineral resource of the upper Missisquoi Valley and vicinity but has never been mined. There is also little evidence that it has been prospected; the only talc prospect known to the authors is a small pit that is located 1.4 miles S. $20^{\circ} \mathrm{E}$. of the road intersection in the village of Westfield. Two small pits in a ledge 1.75 miles $\mathrm{N} .75^{\circ} \mathrm{E}$. of the center of the village of North Troy expose talc and were possibly talc prospects. Reports of talc discoveries extend back at least 100 years (Hitchcock and others, 1861, p. 541,542 ).

Talc has been recovered in cores from diamond-drill holes drilled in the course of exploration for asbestos at several localities but core recoveries of talc are generally poor because of its friability. On Belvidere Mountain, near the Eden Quarry, more than 250 feet of talc-bearing rock was penetrated by a single drill hole. About

\footnotetext{
8 Drilled by the Vermont Asbestos Mines Division of the Ruberoid Company, under contract with the Defense Minerals Exploration Administration.
} 
14 feet of talc rock was recovered from a drill hole on the northeast slope of Leland Hill, in the town of Lowell; and 16 feet was recovered, from immediately beneath overburden, in a drill hole located 1.4 miles south-southeast of the village of Westfield.

The largest bodies of talc-bearing rock discovered in the course of the present geologic investigations are in a linear belt at least 4 miles long and ranging in width from 100 to 1,500 feet that extends south-southeast from the southeastern slopes of East Hill in the town of Troy nearly to Mineral Springs Brook in the town of Westfield. This belt of talc-bearing ultramafic igneous rock was described in a preliminary report (Chidester and others, 1951, p. 15, locality 16). In some places, the talc rock in the belt occupies nearly the full width of the ultramafic body.

Talc rock includes two different types of material: (a) talc-carbonate rock, which is made up of a mixture of the minerals talc and magnesite and (b) steatite, which is composed almost entirely of talc. The mixture of talc and carbonate, which talc miners refer to as "grit," makes up the bulk of the rock, although included with it are lesser quantities of barren serpentinite; it is adjoined outward next to the walls of the ultramafic igneous body by the steatite, which is a few inches to less than a foot thick. Outside the walls of the igneous body is the "blackwall" chlorite rock. The steatite and chlorite rock are very rarely seen because they are thin and because the steatite in particular is easily weathered and eroded. Exposures of the talc-carbonate rock can be seen 0.8 mile $\mathrm{S}$. $70^{\circ}-80^{\circ} \mathrm{E}$. of the highway intersection at the center of the village of Troy.

\section{IRON}

Magnetite was mined more than 100 years ago in the town of Troy, 1.5 miles $\mathrm{N} .45^{\circ} \mathrm{E}$. of the center of the village (Richardson, 1908, p. 285; Hitchcock and others, 1861, p. 722). The ore, which was apparently in irregular masses in serpentinite, was mined in surface pits that are now partly caved and filled with water. Nearly all of the ore was smelted locally.

\section{CHROMITE}

Reports of the discovery of chromite associated with serpentinite, at localities southeast of Troy and southwest of North Troy (Richardson, 1908, p. 286), are well substantiated by early descriptions of this activity (Hitchcock and others, 1861, p. 832-837), which took place in the towns of Troy, Jay, and Westfield. None was apparently of commercial value. The authors have found veins of chromite that are less than an inch thick at the Eden Quarry on the southeastern slopes of Belvidere Mountain in Eden, and a tabular mass that is as much as a foot thick near the west peak of Belvidere Mountain. 
One of the localities of the early reports was at an asbestos prospect 1.2 miles N. $20^{\circ} \mathrm{E}$. of the village of Jay; no chromite was seen there by the writers, however.

\section{COPPER}

Local residents report an occurrence of copper that is located a little east of and downslope from the summit of Black Hill, in the extreme southern part of the town of Newport. This occurrence was not found during the present investigation.

\section{REFERENCES CITED}

Albee, A. L., 1952, Comparison of the chemical analyses of sedimentary and metamorphic rocks (abs.): Geol. Soc. America Bull., v. 63, p. 1229.

1957, Bedrock geology of the Hyde Park quadrangle, Vermont: U.S. Geol. Survey Geol. Quad. Map GQ-102.

Ambrose, J. W., 1942, Preliminary map, Mansonville, Quebec: Canada Geol. Survey Paper 42-1.

- 1943, Preliminary map, Stanstead, Stanstead and Brome Counties, Quebec: Canada Geol. Survey Paper 43-12.

_ـ 1949, Are the "Bolton" lavas of post-Devonian age? (abs.): Royal Soc. Canada Proc., 3d ser., v. 43, p. 239.

1957, The age of the Bolton lavas, Memphremagog district, Quebec: Naturaliste Canadien, v. 84, p. 161-170.

Bain, G. W., 1932, Chrysotile asbestos pt. 2, Chrysotile solutions: Fcon. Geology, v. 27, p. 281-296.

1936, Serpentinization of Vermont ultrabasics: Geol. Soc. America Bull., v. 47, p. 1961-1979.

Billings, M. P., 1948, Orogeny in the Appalachian Highlands of New England: Tulsa Geol. Soc. Digest, v. 16, p. 48-53.

Booth, V. H., 1950, Stratigraphy and structure of the Oak Hill succession in Vermont: Geol. Soc. America Bull., v. 61, p. 1131-1168.

Bowen, N. L., and Tuttle, O. F., 1949, The system $\mathrm{MgO}_{-} \mathrm{SiO}_{2}-\mathrm{H}_{2} \mathrm{O}$ : Geol. Soc. America Bull., v. 60, p. 439-460.

Brace, W. F., 1958, Interaction of basement and mantle during folding near Rutland, Vermont: Am. Jour. Sci., v. 256, p. 241-256.

Cady, W. M., 1945, Stratigraphy and structure of west-central Vermont: Geol. Soc. America Bull., v. 56, p. 515-587.

- 1956, Bedrock geology of the Montpelier quadrangle, Vermont: U.S. Geol. Survey Geol. Quad. Map GQ-79.

1960 , Stratigraphic and geotectonic relationships in northern Vermont and southern Quebec: Geol. Soc. America Bull., v. 71, p. 531-576.

Cady, W. M., and Chidester, A. H., 1957, Magmatic relationships in northern Vermont and southern Quebec (abs.): Geol. Soc. America Bull., v. 68, p. 1705.

Carey, S. W., 1954, The rheid concept in geotectonics: Geol. Soc. Australia Jour., v. 1, p. $67-117$.

Chidester, A. H., 1953, Geology of the talc deposits, Sterling Pond area, Stowe, Vermont: U.S. Geol. Survey Mineral Inv. Field Studies Map MF-11.

1962, Petrology and geochemistry of selected talc-bearing ultramafic rocks and adjacent country rocks in north-central Vermont: U.S. Geol. Survey Prof. Paper 345, $207 \mathrm{p}$.

Chidester, A. H., Billings, M. P., and Cady, W. M., 1951, Talc investigations in Vermont, preliminary report: U.S. Geol. Survey Circ. 95, 33 p. 
Clark, T. H., 1934, Structure and stratigraphy of southern Quebec: Geol. Soc. America Bull., v. 45, p. 1-20.

1936a, Silurian rocks of Lake Memphremagog, Quebec: Canadian Field Naturalist, v. 50, p. 31-33.

1936b, A Lower Cambrian series from southern Quebec: Royal Canadian Inst. Trans., v. 21, pt. 1, p. 135-151.

Clark, T. H., and Fairbairn, H. W., 1936, The Bolton igneous group of southern Quebec: Royal Soc. Canada Trans., 3d ser., v. 30, sec. 4, p. 13-18.

Cooke, H. C., 1937, Thetford, Disraeli, and eastern half of Warwick map areas, Quebec: Canada Geol. Survey Mem. 211, 160 p.

- 1950, Geology of a southwestern part of the Eastern Townships of Quebec: Canada Geol. Survey Mem. 257, 142 p.

1951, [Geological map] Magog-Weedon, Quebec: Canada Geol. Survey Map 994A.

Currier, L. W., and Jahns, R. H., 1941, Ordovician stratigraphy of central Vermont: Geol. Soc. America Bull., v. 52, p. 1487-1512.

Doll, C. G., 1951, Geology of the Memphremagog quadrangle and southeastern portion of the Irasburg quadrangle, Vermont: Vermont Geol. Survey Bull. $3,113 \mathrm{p}$.

Dresser, J. A., 1913, Preliminary report on the serpentine and associated rocks of southern Quebec: Canada Geol. Survey Mem. 22, 103 p.

Dresser, J. A., and Denis, T. C., 1944, Geology of Quebec-v. 2, Descriptive geology: Quebec Dept. Mines Geol. Rept. 20, 544 p.

Fairbairn, H. W., 1933, Chemical changes in metabasalt from southern Quebec: Jour. Geology, v. 41, p. 553-558.

Frondel, Clifford, 1946, Minerals from a Vermont asbestos quarry: Rocks and Minerals, v. 21, p. 490-491.

Grout, F. F., 1932, Petrography and petrology: McGraw-Hill Book Co., 522 p.

Hitcheock, Edward, Hitchcock, Edward, Jr., Hagar, A. D., and Hitchcock, Charles, 1861, Report on the geology of Vermont: Claremont, N. H., v. 1, p. 1-558; v. 2, p. 559-988.

Holmes, Arthur, 1960, A revised geological time scale: Geol. Soc. Edinburgh Trans., v. 17, p. 183-216.

Keith, S. B., and Bain, G. W., 1932, Chrysotile asbestos; 1-Chrysotile veins: Econ. Geology, v. 27, p. 169-188.

Kemp, J. F., 1901, Notes on the occurrence of asbestos in Lamoille and Orleans Counties, Vermont: U.S. Geol. Survey Mineral Resources 1900, p. 862-866.

King, B. C., and Rast, N., 1955, Tectonic styles in the Dalradians and Moines of parts of the Central Highlands of Scotland: Geologists Assoc. Proc., v. 66, p. 243-269.

Kulp, J. L., 1961, Geologic time scale: Science, v. 133, p. 1105-1114.

Lyons, J. B., Jaffe, H. W., Gottfried, David, and Waring, C. L. 1957, Lead-alpha ages of some New Hampshire granites: Am. Jour. Sci., v. 255, p. 527-546.

Marsters, V. F., 1904, A preliminary report on a portion of the serpentine belt of Lamoille and Orleans Counties, Vermont: Vermont State Geologist 4th bien. rept. 1903-04, p. 86-102.

1905, Petrography of the amphibolite, serpentine, and associated asbestos deposits of Belvidere Mountain, Vermont: Geol. Soc. America Bull., v. 16, p. $419-446$.

1906, A preliminary report on a portion of the serpentine belt of Lamoille and Orleans Counties, Vermont: Vermont State Geologist 5th bien. rept. 1905-06, p. 35-61. 


\section{B-74 CONTRIBUTIONS TO ECONOMIC GEOLOGY}

Osberg, P. H., 1952, The Green Mountain anticlinorium in the vicinity of Rochester and East Middlebury, Vt.: Vermont Geol. Survey Bull. 5, 127 p.

1956, Stratigraphy of the Sutton Mountains, Quebec; key to stratigraphic correlation in Vermont (abs.): Geol. Soc. America Bull., v. 67, p. 1820.

Perry, E. L., 1927, Summary report on the geology of Plymouth and Bridgewater, Vt.: Vermont State Geologist 15th bien. rept. 1925-26, p. 160-162.

1929?, The geology of Bridgewater and Plymouth townships, Vt: Vermont State Geologist 16th bien. rept. 1927-28, p. 1-64.

Richardson, C. H., 1908, The geology of Newport, Troy, and Coventry: Vermont State Geologist 6th bien. rept. 1907-08, p. 264-291.

1910, Asbestos in Vermont: Vermont State Geologist 7th bien. rept. 1909-10, p. 315-330.

1911, The asbestos deposits of the New England States: Canadian Min. Inst. Quarterly Bull. 13, p. 59-69, 131-150, Journal 14 (1912), p. 107-137. 1912, The terranes of Craftsbury, Vermont: Vermont State Geologist 8th bien. rept. 1911-12, p. 162-183.

Richardson, C. H., and Collister, M. C., 1912, The terranes of Albany, Vermont: Vermont State Geologist 8th bien. rept. 1911-12, p. 184-195.

Richardson, C. H., and Conway, E. F., 1912, The terranes of Irasburg, Vermont: Vermont State Geologist 8th bien. rept. 1911-12, p. 146-161.

Riordon, P. H., 1954, Preliminary report on Thetford Mines-Black Lake area, Frontenac, Megantic and Wolfe Counties [Quebec]: Quebec Dept. Mines, Mineral Deposits Br., Prelim. Rept. 295, 23 p.

1955, The genesis of asbestos in ultrabasic rocks: Econ. Geology, v. 50, p. $67-81$.

Terry, R. D., and Chilingar, G. V., 1955, Summary of "Concerning some additional aids in studying sedimentary formations," by S. M. Shvetsov: Jour. Sed. Petrology, v. 25, p. 229-234.

Thompson, J. B., Jr., 1955, The thermodynamic basis for the mineral facies concept: Am. Jour. Sci., v. 253, p. 65-103.

Weiss, L. E., 1958, Structural analysis of the basement system at Turoka, Kenya: Great Britain, Overseas Geology and Min. Res. v. 7, p. 3-35, 123-153.

White, W. S., and Billings, M. P., 1951, Geology of the Woodsville quadrangle, Vermont-New Hampshire: Geol. Soc. America Bull., v. 62, p. 647-696.

White, W. S., and Jahns, R. H., 1950, Structure of central and east-central Vermont: Jour. Geology, v. 58, p. 179-220. 


\section{INDEX}

A

Page
B5-6

Acknowledgments.

Altitude of area................ 3

Amphibolite...... 11, 15, 36

Hazens Notch formation 13

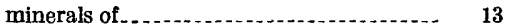

Amphibolites, metamorphic zoning ...... 54

Antigorite.......... 38, 39, 40

Antigorite-chlorite rock.......... 46

lithologic description .................. 42

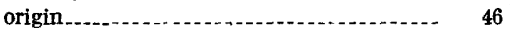

Antigorite-chlorite zone................. 36

Aplite.

Asbestos, dispersed fiber............. 69

geologic relationships _......... $68-70$

in slip planes and veins................ 69

mining, history and development._...... 67-68

prospect pits ........ 68

shipping

slip- and cross-fiber veins............. 70

Asbestos Corp., Ltd.... 6

Asbestos deposits......... 67-70

methods of study

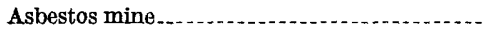

Axial anticline, Green Mountain anticlinorium.

\section{B}

Bear Mountain

$3,4,30,31$

Bedded rocks, deposition of

Bedding.

causes.

66

Bedding foliation.... 58

Belvidere Mountain......................... $40,41,43,44,45,55,56,57,66,67,68,70,71$ carbonate rock synclines

16,56

Belvidere Mountain amphibolite........... 12, $13,14,15-18,56-57$

age

composition............................ 17

correlations and structure........ 16,17

exposures.... 17-18

mode........ 10

type locality

Big Falls _........

Big Jay _........ 6

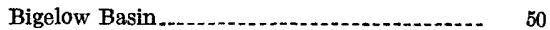

Black Hill._... 24, 52

Browns Ledges_............ 36, 38, 39, 41, 59, 68, 69, 70

Brucite

更

Calc-silicate rock $36,42,46$

origin . .

lithologic description _... . . . . . . . . 41-42

Caldwell group, of Cooke... 11

Camels Hump group, age.......... 7

Canadian Pacific Railroad.................. 4

Carbonaceous zones, Hazens Notch formation. 11, 12

Carbonate........... 39,40

Carbonate rock, distribution

lithologic description . . . . . . $43-44$ origin . ............. 46-47

Carbonatization............... 47

Chlorite.............. 39

Chlorite rock

lithologic description........... 44-45

origin . . . 47

Chromite........ 38,39

early mining . $71-72$

Chrysotile............. 40

Chrysotile fibers....... 69

Cirques . . . .

Cleavage . ....... $63-64$

Coburn Hill_._._.

Coburn Hill volcanic member of Moretown

formation _... 27, 28 definition........................ 27

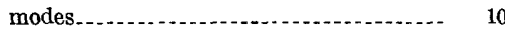

Compositional layering ............... 10, 14, 24

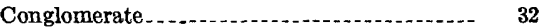

Contact metamorphic aureoles.......... 55

Contact, metamorphic rocks............ 30-31, 36 volcanic member . . . . . . . . . $30-31,34,36$

Contact metamorphism _......_._._._. 46, 55

Copper, occurrence of.

Corez Pond. 6

Cross-fiber asbestos veins... _...

Cross folds ................... 60-61, 63,64

\section{D}

Defense Minerals Exploration Administration . 70

Diamond drilling

Discontinuities...................................... 64

Dispersed-fiber asbestos deposits _..._._._... $\quad 69$

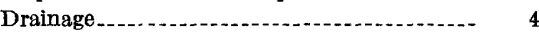

Drilling program.

Dunite

differential serpentinization............ 59

distribution in pluton................. 35

mode....... 34,35

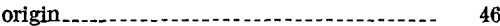

Dunite and alteration products, lithologic description. ...... 36-38 


\section{$\mathbf{E}$}

East Hill

East Richford

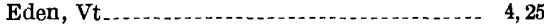

Eden Mills-Craftsbury area, Umbrella Hill formation.

Eden Notch, greenstone

Eden Quarry $43,67,71$

Eltey Mountain $27,52,55$

Eltey Mountain granite ................... 31, 62 age

contact metamorphic effect

exposures

metamorphic action ................... 24 mode..

Eskers

Exploration, guides for 69-70

F

Facies gradations

Farman Hill

Fault, east flank of Gilmore anticline.

Faults.

Fold layers.

Folding age

Folds and crinkles

Foot Brook syncline

Fourchite.

53-54

Fractional crystallization

Fracture cleavage

\section{G}

Gallagher pit 67,69

Garnet.

General geology of area

Geography of area.

Geological Society of America, correlation project. ...................

Geological Survey of Canada.

Geology of area

Geophysical exploration

Geosyncline

Gihon River valley of

Gilmore anticline

Gilpin Mountain $56,64,65,66-67$

Glacial action, physiographic effects.

Glaciation, continental.

Glenbrooke shale, age

Gneiss, Hazens Notch formation

Granite

Granulite.

Green Mountain anticlinorium _...- 6, 11, 56, 57,61, 67 age.

physiography

Green Mountains.

Greenstone metamorphosed pillow structure

Hadley Mountain.
H

\section{Page}

B13, 17

Haystack Mountain.

Hazens Notch
Hazens Notch formation $\ldots \ldots \ldots \ldots \ldots$

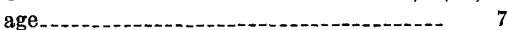

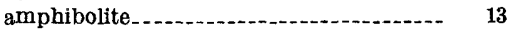

definition, extent, and thickness.......... 11

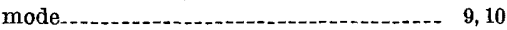

type locality ............................. 13

Hyde Park. . .

\section{I}

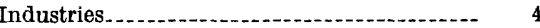

Intrusive igneous rocks, modes. ............ 34

Intrusive igneous rocks and alteration prod-

ucts.................................... 34-54

Irasburg, Vt

Iron, magnetite mining

$\mathbf{J}$

Jay, Vt_......... $13,54,68,71$

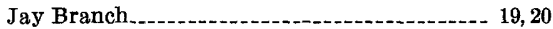

Jay Peak

Jay Peak formation, age

amphibolite............................ 15

correlations................. 14

definition and extent.................... 13-14

exposures...................................... 15

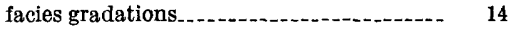

mode-.... 9

rocks and minerals. ..................... 14-15

Jay Peak syncline.

Joints_... .

$\mathbf{L}$

Lake Champlain

Lake Eden

Lamoille River................................... 4

Lamprophyre. . . .

age

lithologic description. . . . .

mode....................................... 34 35

Laval University

Layering -................... 41,57,63

in ultramafic rocks.

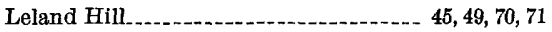

Limestone................ 32

Little Jay. . . .

Location of area......... 2-3

Long Trail_.

Longitudinal folds_............. 59-66, 63, 64, 65, 66-67

Lowell Mountain anticline......... 23, 25, 27, 56, 60,

Lowell Mountains................... 3, 22, 23, 24, 56,

Lowell Quarry _.......... 41, 45, 55, 57, 62, 64, 68, 69, 70, chrysotile asbestos................... 40,67, faults..................................... 62

Lowell, Vt................ 4, 21, 22, 24, 27, 45, 49, 68, Lowell village, $\mathrm{Vt}$............... $30,36,38,39,41,49,50$

\section{M}

Magnetite.................................. 38, 39, 40

Magnetometer surveys...................... 35 


\section{INDEX}

Page

Metagabbro B34, 54,

age

exposures

metamorphism of

49

mode.

Metagabbro and alteration products, lithologic description

34,35

Metagabbro sill

Metamorphic differentiations.

Metamorphic zoning.

Metamorphism.

age...

heat source.

Metamorphosed sedimentary rocks, estimated modes

Metamorphosed sedimentary and volcanic rocks ..................................

Metamorphosed volcanic rocks, estimated modes.

mode of occurrence.

Metasomatism.

Missisquoi River

Missisquoi Valley

Missisquoi Valley syncline.

Modal analysis, methods.

Modal estimates, selected metamorphosed sedimentary rocks

Montgomery.-

Moretown formation, age

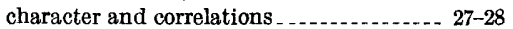

Coburn Hill volcanic member, amphibolite. greenstone

modes

phyllite-slate.

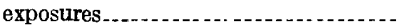
quartz-sericite-albite-chlorite granulite, character and minerals.

fabric

quartz-sericite-chlorite phyllite-slate...... sericitic and chloritic quartzite, composition and exposures

Morrisville, $\mathrm{Vt}$

Mount Norris

\section{$\mathbf{N}$}

Newport, Vt , 26, 27, 31, 62

Newport Center, Vt_........_....... 4, 24, 25, 29

Noncarbonaceous gneiss and schist

North Troy. $3,4,11,22,49,70$

Northfield slate, age.

character and distribution.

mode.

$\mathbf{O}$

Old Splatterfoot Mountain

Ottauquechee formation, age..................... carbonaceous phyllite, description and exposures

carbonaceous quartzite.

distribution and composition

exposures.

intergradations

lithic types.

modes.
Ottauquechee formation, age-Continued Page phyllitic graywacke_.................. B21-22 quartz-sericite-chlorite phyllite. . . . . . . 20-22 relation to Jay Peak formation .......... 14

\section{$\mathbf{P}$}

Peasley Pond conglomerate, age

Peridotite............. 35 origin

Peridotite and alteration products, lithologic description

Phelps Falls

Philip Cary Manufacturing Co., drilling....- 68

Phyllite................ 22, 23-24, 32, 50 sericite-quartz-chlorite-albite_......... 21, 22, 23

Phyllite-slate.......................... 27, 28, 29

Phyllitic conglomerate..................... 25-26

Phillitic graywacke................. 21, 22-23, 25

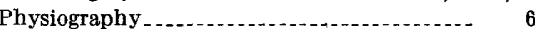

Pillow strueture.

Plutons, distribution of rocks in _......... 35 geophysical surveys _........ $35-36$

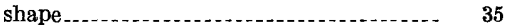
zonal relations at contacts . . . . . . . . $\quad 37$

Porphyroblasts........ 12

Present investigation ...

Previous work

Quartz, aggregates................. 12

Quartzite

in Hazens Notch formation....... 12

Quebec Department of Mines.............. 5-6

Quebec Department of Natural Resources... 6

\section{$\mathbf{R}$}

References cited ........ $72-74$

Refusion ............ 46

Regional metamorphism............ 46-47, 55

Roads and trails...... . . .

Rocks of area, summary .................. 7

Ruberoid Co., Vermont Asbestos Mines Division

\section{$\mathbf{S}$}

St. Johnsbury and Lamoille County Railroad. Schist, carbonaceous quartz-sericite-chlorite . in Hazens Notch formation, description and exposures.................... 12,13 quartz- sericite-albite-chlorite........... 11 sercite-quartz-chlorite-albite................ 22

Schist, gneiss, and quartzite, exposures....... 13 mineral composition................... 12 variations and zoning .................... 11-12 Schist-quartzite assemblage

Schistosity .......... 20, 69

Schists, gradations.......................... 8

Schofield Ledges

Serpentinite _... . . . . 34, 35, 36, 38, 45, 46, 69, 71 asbestos................. 69 mode........... 34

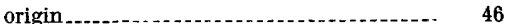

Serpentinite and alteration products, lithologic description................... 39-41 


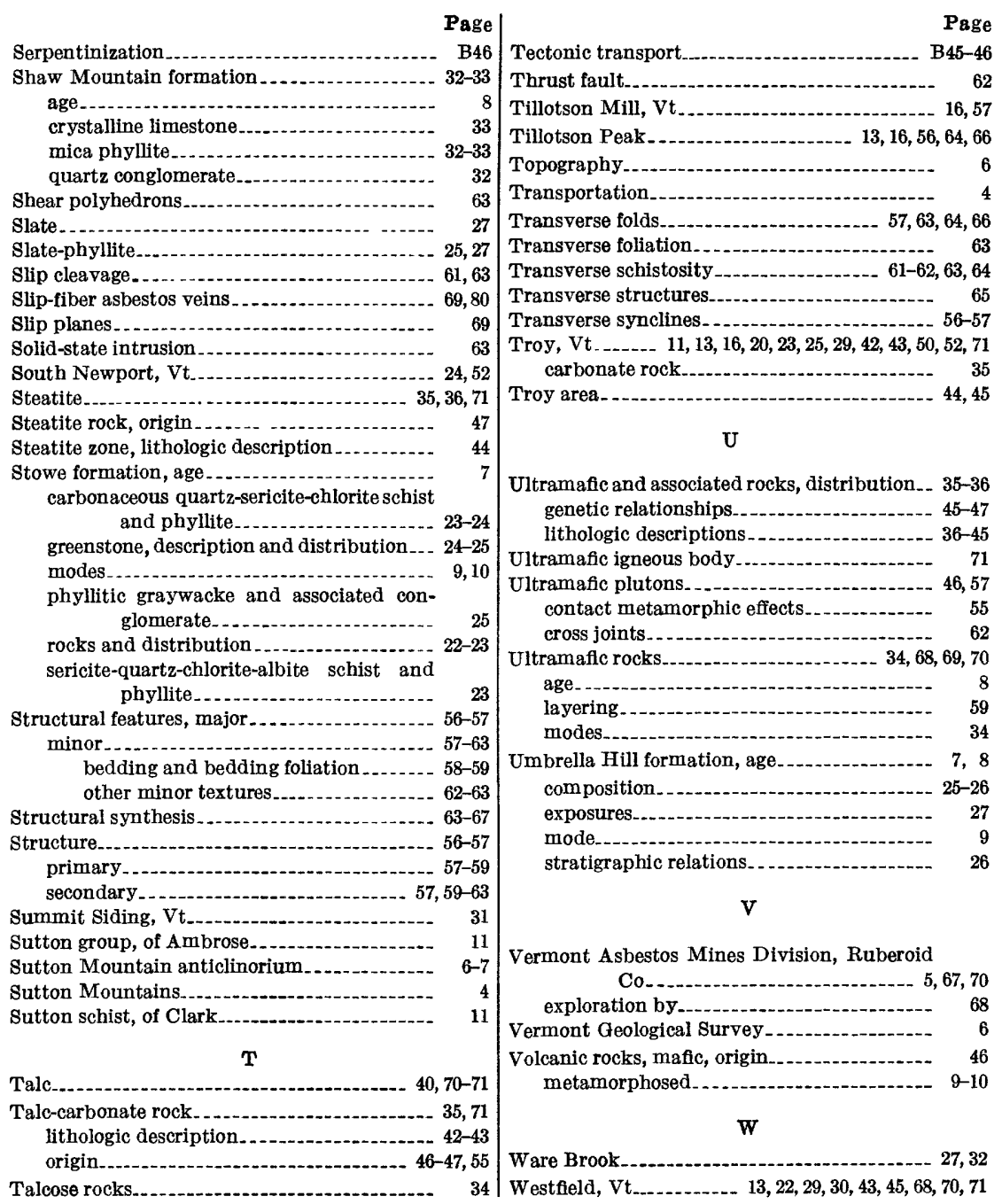

